Water Availability and Use Science Program

\title{
Groundwater Availability in the Ozark Plateaus Aquifer System
}

\section{ZUSES}

Water Availability and Use Science Program

Altitudes and Thicknesses of Hydrogeologic Units of the Ozark Plateaus Aquifer System in Arkansas, Kansas Missouri, and Oklahoma

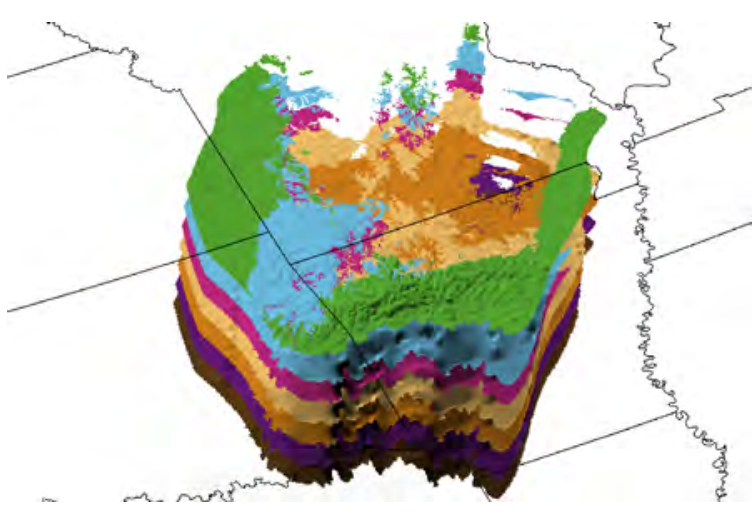

Scientific Investigations Report 2016-5130

U.S. Department of the Interio U.S. Geological Survey

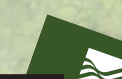

2055

Hydrogeologt

plateals

Sint

क.

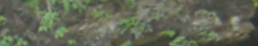

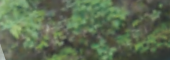

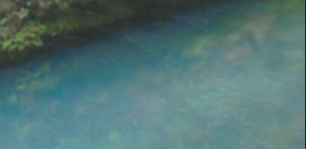

Professional Paper 1854

U.S. Department of the Interior

U.S. Geological Survey 
Cover and page i: Photographs by Drew A. Westerman, used with permission. 


\section{Groundwater Availability in the Ozark Plateaus Aquifer System}

By Brian R. Clark, Leslie L. Duncan, and Katherine J. Knierim

Water Availability and Use Science Program

Professional Paper 1854 


\title{
U.S. Department of the Interior \\ DAVID BERNHARDT, Secretary
}

\author{
U.S. Geological Survey \\ James F. Reilly II, Director
}

U.S. Geological Survey, Reston, Virginia: 2019

For more information on the USGS - the Federal source for science about the Earth, its natural and living resources, natural hazards, and the environment-visit https://www.usgs.gov or call 1-888-ASK-USGS.

For an overview of USGS information products, including maps, imagery, and publications,

visit https://store.usgs.gov.

Any use of trade, firm, or product names is for descriptive purposes only and does not imply endorsement by the U.S. Government.

Although this information product, for the most part, is in the public domain, it also may contain copyrighted materials as noted in the text. Permission to reproduce copyrighted items must be secured from the copyright owner.

Suggested citation:

Clark, B.R., Duncan, L.L., and Knierim, K.J., 2019, Groundwater availability in the Ozark Plateaus aquifer system: U.S. Geological Survey Professional Paper 1854, 82 p., https://doi.org/10.3133/pp1854.

ISSN 2330-7102 (online) 


\section{Foreword}

Although often overlooked, groundwater is increasingly important to all our lives. Groundwater is the Nation's principal reserve of freshwater. It provides drinking water for half of the country, is essential to food production in the United States, and facilitates business and industrial activities. Groundwater also is an important source of water for sustaining the ecosystem health of rivers, wetlands, and estuaries throughout the country.

Groundwater level declines resulting from large-scale development of groundwater resources, together with other effects of pumping, have led to concerns about the future availability of groundwater to meet our Nation's needs. The compounding effects of recent droughts underscore the need for an updated status of the Nation's groundwater resources. Assessments of groundwater resources provide the science and information needed by decision makers and the public to manage and use water resources responsibly. The potential future effects on groundwater resources due to climate variability further exacerbate an already challenging situation, and the analysis of these potential effects add to an already complex task.

The U.S. Geological Survey's Water Availability and Use Science Program is conducting largescale multidisciplinary regional studies of groundwater availability, including the study of the Ozark Plateaus aquifer system described herein. The regional studies are intended to inform citizens, communities, and natural resource managers of the condition of the Nation's groundwater resources and how changes in land use, water use, and climate have affected those resources. The studies also are aimed at developing tools to enable scientists and managers to forecast how these resources may change in the future. The findings from these individual groundwater assessments of principal aquifer systems will be combined to form a national assessment of groundwater availability. Results derived from these studies will help answer questions about the Nation's ability to meet current and future demands for groundwater.

Donald Cline

Associate Director, USGS Water Resources Mission Area 



\section{Contents}

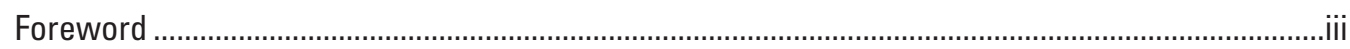

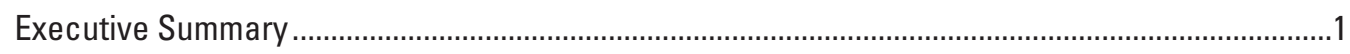

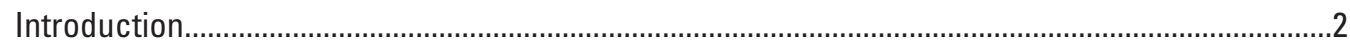

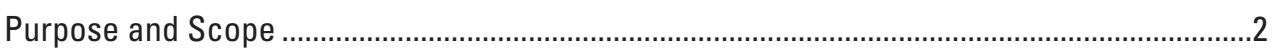

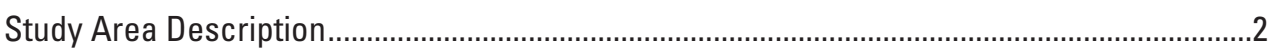

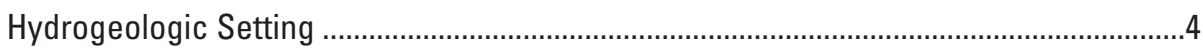

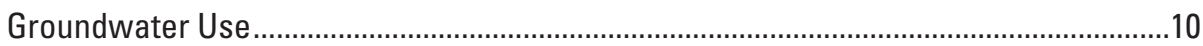

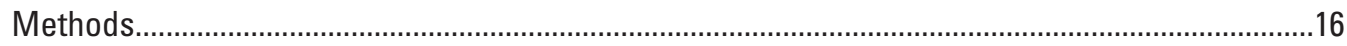

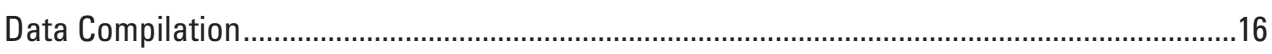

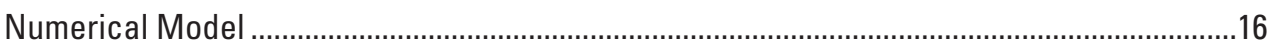

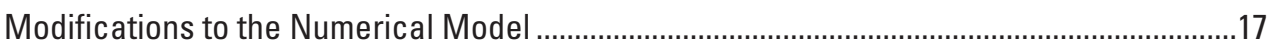

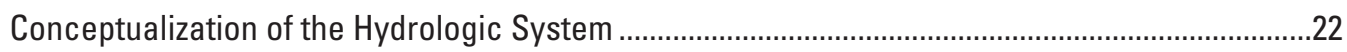

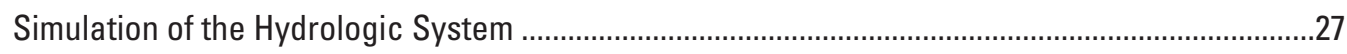

Comparison of the Conceptualized and Simulated Hydrologic Systems ................................27

Comparison of Predevelopment Conditions Between the Conceptualized and Simulated Hydrologic Systems .........................................................................27

Comparison of Postdevelopment Conditions Between the Conceptualized and

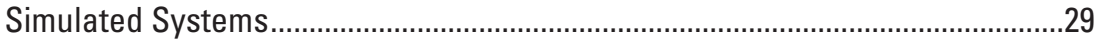

Hydrologic Budget—Groundwater Availability ...............................................................30

Changes in the Hydrologic Budgets Over Time .................................................................30

Changes in Groundwater Storage and Water Levels ......................................................38

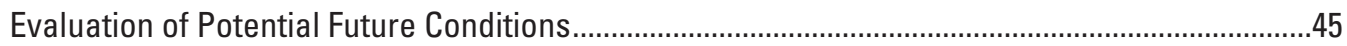

Baseline and Pumping Scenario Simulation Assumptions and Limitations ............................45

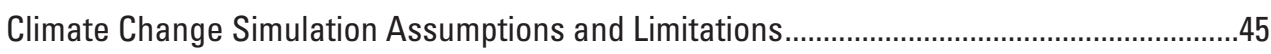

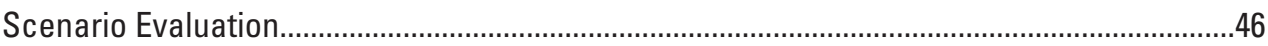

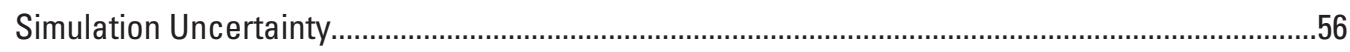

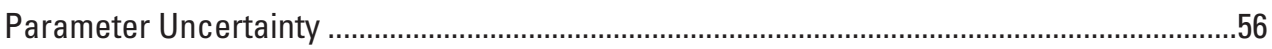

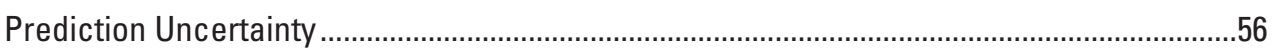

Data-Worth Analysis—Use of Numerical Models to Inform Groundwater Networks ...................61

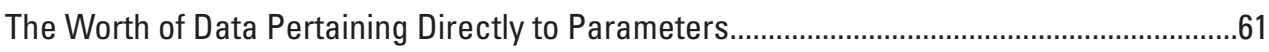

The Worth of Data Pertaining Indirectly to Observations .........................................................61

Challenges for Future Groundwater Availability Assessments—Lessons Learned........................62

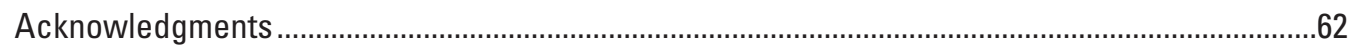

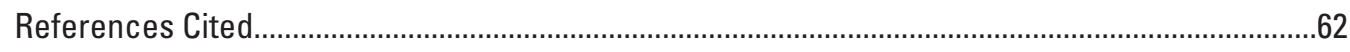

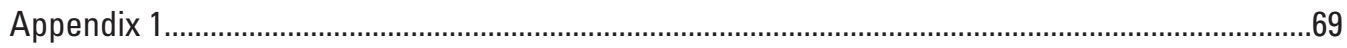

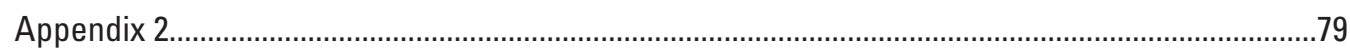

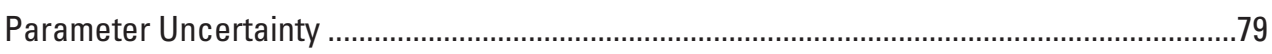

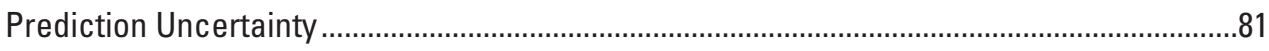

The Worth of Data Pertaining Directly to Parameters...........................................................81

The Worth of Data Pertaining Indirectly to Observations......................................................82 


\section{Figures}

1. Map showing surficial geology and structural features of the Ozark Plateaus aquifer system and boundary conditions for the numerical model of the Ozark Plateaus aquifer system.

2. Stratigraphic column showing generalized correlation of Paleozoic-age stratigraphic units, regional hydrogeologic units of the Ozark Plateaus aquifer system, and corresponding model layer numbers

3. Cross sections showing hydrogeologic units of the Ozark Plateaus aquifer system (Ozark system) using the updated hydrogeologic framework from Westerman and others

4. Pie graphs showing modeled groundwater use in 2010 from the Ozark

Plateaus aquifer system by State, water-use division, and hydrogeologic unit and model layer

5. Maps showing horizontal hydraulic conductivity of select model layers within the Ozark model area

6. Hydrologic budget for conceptual model of Hays and others for predevelopment and postdevelopment conditions and numerical analysis in this report of predevelopment (before 1900) and average postdevelopment conditions

7. Pie graphs showing distribution of groundwater withdrawals by percentage in summer 2010 by hydrogeologic unit and model layer for the Ozark Plateaus aquifer system and each geographic area in the Ozark Plateaus aquifer system: Arkansas, Kansas, Oklahoma, Missouri, and southwest Missouri

8. Graphs showing groundwater-flow budget for Ozark model version 1.1 of large water-budget components and small water-budget components.

9. Graphs showing distribution of groundwater withdrawals by regional aquifer for the Ozark Plateaus aquifer system and each geographic area in the Ozark Plateaus aquifer system: Arkansas, Kansas, Oklahoma, Missouri, and southwest Missouri...

10. Graphs showing cumulative recharge, pumping, and storage for the Ozark Plateaus aquifer system and each geographic area in the Ozark Plateaus aquifer system: Arkansas, Kansas, Oklahoma, Missouri, and southwest Missouri.

11. Map showing water-level change from predevelopment to 1965 for the Ozark Plateaus aquifer system

12. Map showing water-level change from predevelopment to 1980 for the Ozark Plateaus aquifer system.

13. Map showing water-level change from predevelopment to 1988 for the Ozark Plateaus aquifer system.

14. Map showing water-level change from predevelopment to 2009 for the Ozark Plateaus aquifer system 
15. Map showing water-level change from predevelopment to 2060 for the Ozark Plateaus aquifer for the baseline scenario.

16. Map showing water-level change from predevelopment to 2060 for the Ozark Plateaus aquifer for the pumping scenario.

17. Map showing water-level change from predevelopment to 2060 for the Ozark Plateaus aquifer for the general circulation model scenario

18. Graphs showing hydrologic budget for each scenario developed to simulate potential future conditions from 2015 to 2060 in the Ozark Plateaus aquifer system: the baseline scenario, the pumping scenario, and the general circulation model scenario

19. Graphs showing storage change from 2015 to 2060 for the baseline scenario for the Ozark Plateaus aquifer system and Ozark aquifer.

20. Graphs showing storage change from 2015 to 2060 for the pumping scenario for the Ozark Plateaus aquifer system and Ozark aquifer

21. Graphs showing storage change from 2015 to 2060 for the general circulation model scenario for the Ozark Plateaus aquifer system and Ozark aquifer

22. Graph showing the margin of error, or radius, of the 95-percent credible interval for the prior and posterior predictive uncertainty of head during the 2016-60 model period for the baseline scenario at real-time observation wells of interest in the Ozark Plateaus aquifer system.

23. Graph showing the margin of error, or radius, of the 95-percent credible interval for the prior and posterior predictive uncertainty of head during the 2016-60 model period for the general circulation model scenario at real-time observation wells of interest in the Ozark Plateaus aquifer system

24. Graph showing the margin of error, or radius, of the 95-percent credible interval for the prior and posterior predictive uncertainty of head during the 2016-60 model period for the pumping scenario at real-time observation wells of interest in the Ozark Plateaus aquifer system.

\section{Tables}

1. Summary of hydraulic-head residual statistics for calibration of the Ozark groundwater-flow model, version 1.1

2. Hydrologic budget for the numerical groundwater-flow model for the predevelopment period (before 1900) and minimum, average, standard deviation, and maximum values for the postdevelopment period (April 1, 1996, to April 1, 2016).

3. Percent reduction in uncertainty associated with groups of adjustable model parameters 


\section{Conversion Factors}

U.S. customary units to International System of Units

\begin{tabular}{lcl}
\hline \multicolumn{1}{c}{ Multiply } & By & \multicolumn{1}{c}{ To obtain } \\
\hline inch (in.) & Length & \\
foot $(\mathrm{ft})$ & 2.54 & centimeter $(\mathrm{cm})$ \\
mile $(\mathrm{mi})$ & 0.3048 & meter $(\mathrm{m})$ \\
& 1.609 & kilometer $(\mathrm{km})$ \\
\hline square mile $\left(\mathrm{mi}^{2}\right)$ & Area & \\
\hline & 2.590 & square kilometer $\left(\mathrm{km}^{2}\right)$ \\
\hline gallon (gal) & Volume & \\
million gallons (Mgal) & 3.785 & liter $(\mathrm{L})$ \\
\hline & 3,785 & cubic meter $\left(\mathrm{m}^{3}\right)$ \\
\hline gallon per minute $(\mathrm{gal} / \mathrm{min})$ & Flow rate & \\
gallon per day $(\mathrm{gal} / \mathrm{d})$ & 0.06309 & liter per second $(\mathrm{L} / \mathrm{s})$ \\
million gallons per day $(\mathrm{Mgal} / \mathrm{d})$ & 0.003785 & cubic meter per day $\left(\mathrm{m}^{3} / \mathrm{d}\right)$ \\
inch per year (in/yr) & 0.04381 & cubic meter per second $\left(\mathrm{m}^{3} / \mathrm{s}\right)$ \\
\hline & 25.4 & millimeter per year $(\mathrm{mm} / \mathrm{yr})$ \\
\hline foot per day (ft/d) & Hydraulic conductivity & \\
\hline
\end{tabular}

\section{Datum}

Vertical coordinate information is referenced to the North American Vertical Datum of 1988 (NAVD 88).

Horizontal coordinate information is referenced to the North American Datum of 1983 (NAD 83). Altitude, as used in this report, refers to distance above the vertical datum. 


\section{Abbreviations}

CMIP5 5th Climate Model Intercomparison Project

$\mathrm{CO}_{2} \quad$ carbon dioxide

EWB empirical water balance

GCM general circulation model

GHG greenhouse gas

NEX-DCP30 National Aeronautics and Space Administration Earth Exchange Downscaled Climate Projections

Ozark system Ozark Plateaus aquifer system

Ozark Plateaus Ozark Plateaus Physiographic Province

RCP Representative Concentration Pathways

RMSE root mean square error

SWB soil-water balance

USGS U.S. Geological Survey

v1.0 Ozark groundwater availability model, version 1.0

v1.1 Ozark groundwater availability model, version 1.1

WBM water-balance model 


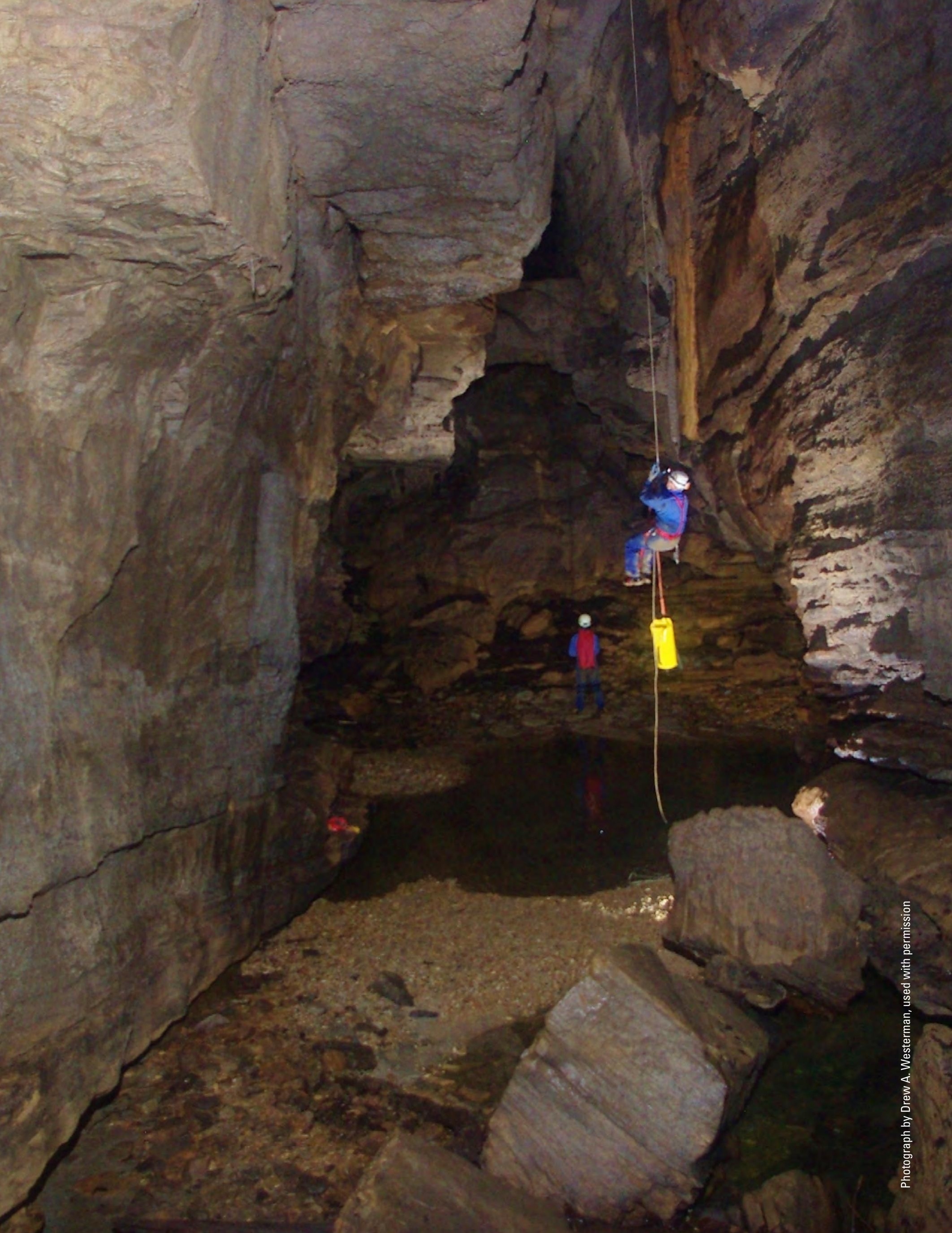




\title{
Groundwater Availability in the Ozark Plateaus Aquifer System
}

\author{
By Brian R. Clark, Leslie L. Duncan, and Katherine J. Knierim
}

\section{Executive Summary}

The study described in this report, initiated by the U.S. Geological Survey in 2014, was designed to evaluate fresh groundwater resources within the Ozark Plateaus, central United States, as an area within a broader national assessment of groundwater availability. The goals of the Ozark study were to evaluate historical effects of human activities on water levels and groundwater availability, quantify groundwater resources now and under probable future pumping and climate conditions, and evaluate existing monitoring networks for their value in making better predictions of future groundwater resources. Previous studies include simulation of local-scale groundwater flow under varying temporal scales, or simulation of the regional system under steady-state conditions. While these studies are useful, particularly for the problem for which they were designed, there is a need to look at the larger regional system under transient conditions to fully evaluate the water resource over time. This study focused on multiple spatial and temporal scales to examine changes in groundwater pumping, storage, and water-level declines. The regional scale provides a broad view of the sources and demands on the system with time.

The study area covers approximately 68,000 square miles in the central United States in parts of Missouri, Arkansas, Kansas, and Oklahoma and encompasses the Ozark Plateaus Physiographic Province (Ozark Plateaus), including the Salem Plateau, Springfield Plateau, and Boston Mountains. Groundwater is withdrawn from the Ozark Plateaus aquifer system (Ozark system) for public supply and for domestic, agriculture (including irrigation and aquaculture), livestock, and non-agricultural use (including industrial, thermoelectric power generation, mining, and commercial). The Ozark system provides an important drinking-water supply for people living in the Ozark Plateaus because public supply and domestic use combined constitute the largest groundwater use. Precipitation is the ultimate source of freshwater to the Ozark system; most rainfall occurs during April, May, and June, and precipitation increases generally from north to south across the study area.

Groundwater use currently accounts for only 10 percent of the total water use in the areas overlying the Ozark system, but provides a critical drinking-water resource because public supply and domestic groundwater withdrawals are largely from groundwater resources. The 380 million gallons per day of groundwater withdrawn from the Ozark system in 2010 accounts for approximately 2 percent of recharge. Although groundwater use represents a small component of the hydrologic budget, because of low storage in aquifer units, cones of depression with steep water-level gradients can develop quickly around pumping centers.

The amount of water entering and leaving the aquifer system from 1900 to about 1965 was relatively constant at a rate of about 13 billion gallons per day (Bgal/d). Much of this inflow of water is discharged through streams in the system to balance the hydrologic budget. Changes in storage over time (from outflows to inflows) reflect the large variability in recharge: if recharge decreases, water levels will decrease, resulting in less groundwater discharge to streams and more water released from aquifer storage. Conversely, when recharge increases, water levels increase, more groundwater discharges to streams, and aquifer storage is replenished. Although pumping generally increased from 1900 to 2016, it does not appear to correlate with the change in storage over the same time period. Regionally, simulated change in groundwater storage corresponds with changes in recharge, more so than with increases in pumping.

Average recharge was $11.6 \mathrm{Bgal} / \mathrm{d}$ for the period 1900 to 2016. Recharge was generally above average from predevelopment to 1965 , followed by a period of belowaverage recharge from 1965 to about 1980. Recharge remained consistently above average from 1980 to about 1988, after which there was a period of average or below-average recharge, reflected by a decline through the mid-2000s.

The implications and potential effects of increased pumping and long-term climate change on the Ozark Plateaus hydrologic system and groundwater availability are a concern for communities and resource managers in the area. Pumping varies from year to year, but is generally expected to moderately increase with population, industrial, and agricultural needs. Most climate models predict warmer minimum and maximum air temperatures by midcentury in the Ozark Plateaus area, especially from midspring through early fall. Three scenarios were developed to simulate possible future conditions from 2016 to 2060 and assess the potential effects on the hydrologic system and availability of 
water resources. For each scenario, changes in water levels and hydrologic budget components were evaluated from predevelopment (1900) to present (2016) and 45 years into the future (2060). The baseline scenario represents an extension of the average (1996 to 2016) seasonal pumping and recharge values. The pumping scenario is an extension of the average (1996 to 2016) seasonal recharge values with increases in pumping following the historical trend for the period 20162060 of up to 120 percent of the 1996 to 2016 average seasonal pumping values. The general circulation model (GCM) scenario is an extension of the average (1996 to 2016) seasonal pumping values and variable recharge based on seasonal averages of soil water storage from a water-balance model using temperature and precipitation from multiple GCMs.

The general patterns of water-level decline are similar for each scenario. The areas of water-level decline in southwest Missouri and northeast Oklahoma are only marginally different by 2060 from those of 2009. In one area south of Springfield, Mo., water-level declines are less in the baseline and GCM scenarios than in 2009. This may be the result of a transition from groundwater use to surface-water supplies for a larger percentage of the demand in the area.

For all three scenarios, forecasted pumping, recharge, and aquifer properties play an important role in determining the uncertainty of water-level forecasts at 94 real-time observation wells. Simulated aquifer properties in the productive middle and lower Ozark aquifers and the St. Francois confining unit of the Ozark system contribute most to predictive uncertainty in water levels at approximately 35 percent of the real-time observation wells. Out of the 94 real-time observation wells, 82 are developed in the lower Ozark aquifer.

\section{Introduction}

Fresh groundwater in the Ozark Plateaus aquifer system (hereafter referred to as the Ozark system) is the source of drinking water for more than 2 million people through municipal and rural water districts and private domestic wells and is also withdrawn for industrial and agricultural uses. The Ozark system is composed predominantly of fractured and dissolved carbonate rock (karst). Groundwater storage values are relatively low, but conductance through fractures and dissolution-enlarged conduits can be high enough that the aquifer system responds rapidly to hydrologic stresses from climatic and human-induced events. For example, seasonal water-level declines have been observed in Ozark system aquifers throughout southeastern Kansas, northeastern Oklahoma, and southwestern Missouri. In this area, groundwater is under confined conditions, such that relatively small amounts of pumping often result in deep cones of depression. Municipal water suppliers have expressed concerns over groundwater availability, particularly during low-recharge, high-use times. These concerns often relate to short-term, seasonal conditions where a few months of drought can result in large groundwater-level declines because of the low storage values of the aquifer system.

Previous studies included simulation of local-scale groundwater flow under varying temporal scales, or simulation of the regional system under steady-state conditions. While these studies are useful, particularly for the problem for which they were designed, there is a need to consider the larger regional system under transient conditions, including shortterm seasonal changes, to fully evaluate the water resource over time. In 2014, the U.S. Geological Survey (USGS) Water Availability and Use Science Program initiated an assessment of groundwater availability of the Ozark system as one of several ongoing regional assessments of the principal aquifers of the Nation (Reilly and others, 2008).

\section{Purpose and Scope}

The purpose of this report is to describe the historical, current, and possible future availability of groundwater in the Ozark system. This study synthesizes results from companion reports that interpreted the hydrogeologic framework (Westerman and others, 2016a, b), refined the conceptual model of the flow system (Hays and others, 2016), analyzed recent groundwater-level measurements (Nottmeier, 2015), estimated historical groundwater-use rates (Knierim and others, 2017), and described the construction and calibration of the groundwater-flow model version 1.0 (Clark and others, 2018). Model version 1.0 was modified to version 1.1 and used herein to understand how a range of future conditions may affect future water resources. This report also documents the changes from version 1.0 of the groundwater-flow model to version 1.1 and builds on previous work at a variety of scales that has taken place across the area for many years by various Federal, State, and local agencies. The analysis includes discussion of associated flow through all aquifers and confining units in the Ozark system during 1900-2016.

\section{Study Area Description}

The study area covers approximately 68,000 square miles $\left(\mathrm{mi}^{2}\right)$ in the central United States in parts of Missouri, Arkansas, Kansas, and Oklahoma (fig. 1) and encompasses the Ozark Plateaus Physiographic Province (hereafter, the Ozark Plateaus), including the Salem Plateau, Springfield Plateau, and Boston Mountains (Hays and others, 2016, fig. 1). The Ozark system is generally bounded by the Missouri River on the northern boundary, the Mississippi River and more broadly the Mississippi embayment to the east and southeast, and the Arkansas River to the south (fig. 1). The western boundary is defined by a regional topographic low extending from northeastern Oklahoma to the Missouri River and coincides with a freshwater-saltwater transition zone (fig. 1) where freshwater from the Ozark system mixes with saltwater from the Western Interior Plains aquifer system (Hays and others, 2016; Jorgensen and others, 1996). The bottom of the Ozark 


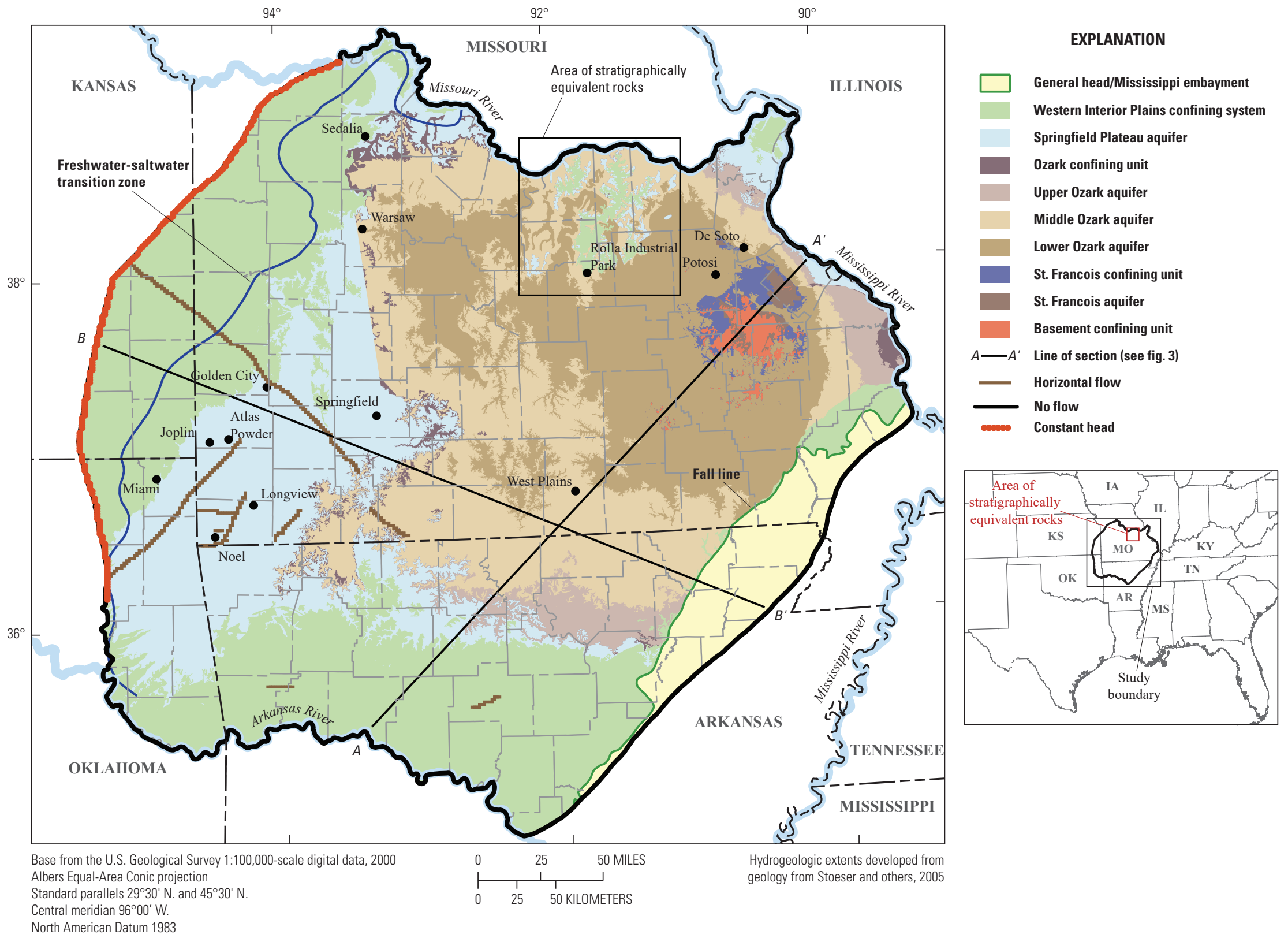

Figure 1. Surficial geology and structural features of the Ozark Plateaus aquifer system and boundary conditions for the numerical model of the Ozark Plateaus aquifer system. 
system is bounded by metamorphic and igneous rocks of Precambrian age (Basement confining unit) that underlie much of the midwestern aquifers in the central United States (Jorgensen and others, 1993).

\section{Hydrogeologic Setting}

The Ozark system is characterized by uplifted plateaus composed of relatively flat-lying sedimentary rocks of Paleozoic age that drape over basement rocks of Precambrian age. The hydrogeologic framework consists of interbedded carbonate and clastic units ranging in age from Cambrian to Early Pennsylvanian (Hays and others, 2016; Jorgensen and others, 1996; Westerman and others, 2016a) (fig. 2). Sandstone and karstified limestone and dolostone units serve as primary aquifers, and shale or dense dolostone generally act as confining units. In ascending order, the units include the Basement confining unit, St. Francois aquifer, St. Francois confining unit, lower Ozark aquifer, middle Ozark aquifer, upper Ozark aquifer, Ozark confining unit, Springfield Plateau aquifer, and Western Interior Plains confining system (Hays and others, 2016; Jorgensen and others, 1993; Westerman and others, 2016a) (fig. 2). Substantial refinement of the hydrogeologic framework was accomplished by Westerman and others $(2016 \mathrm{a}, \mathrm{b})$ by building on regional groundwater studies from Jorgensen and others (1993) and Imes and Emmett (1994) and many State- and smaller-scale studies (for example, Harvey and others, 1983; Howe and Koenig, 1961; Miller and Vandike, 1997). Westerman and others (2016a, b) compiled borehole data and interpreted lithologic information to assign hydrogeologic units for the study area, creating framework grids of hydrogeologic units' altitude and thickness. As part of the updated hydrogeologic framework, the Ozark aquifer was refined into three units (lower, middle, and upper) based on unique hydraulic properties (Westerman and others, 2016a, b), which contributed to a more refined groundwater-flow model than those used in earlier studies.

The Basement confining unit is generally buried under 1,700 to 2,700 feet (ft) of Paleozoic-age rocks throughout the Ozark system (except where exposed, fig. 1), and the top of the unit dips sharply towards the south (Westerman and others, 2016b) (fig. 3). The unit exhibits very low permeability owing to the igneous and metamorphic rocks that compose the basement complex (Jorgensen and others, 1993) and therefore was not explicitly modeled for this study. Because the Basement confining unit forms the structural base for the Ozark system, however, the geometry affects the presence, thickness, and structure of the overlying sedimentary units (Westerman and others, 2016a). The geometry of the Basement confining unit - including relative thickness, dip, and degree of faulting also exerts control on groundwater flow and karst development in overlying sedimentary strata (Brahana and others, 2009), such that the hydrogeologic framework from Westerman and others $(2016 \mathrm{a}, \mathrm{b})$ provides an important updated coverage of Basement confining unit depth across the Ozark system.
The basal hydrogeologic unit of the Ozark system is the St. Francois aquifer of Cambrian age (fig. 2), which has a median thickness of $291 \mathrm{ft}$ (Westerman and others, 2016b) and is composed of permeable sandstones and dolostones (Hays and others, 2016). Although wells penetrating the aquifer yield water, the St. Francois aquifer is generally not used beyond its outcrop area near the St. Francois Mountains because of shallower sources of water available throughout much of the Ozark system (Hays and others, 2016; Imes and Emmett, 1994). The St. Francois aquifer is confined throughout much of its extent where overlain by the St. Francois confining unit. The St. Francois confining unit of Cambrian age has a median thickness of $228 \mathrm{ft}$ (Westerman and others, 2016a) and is composed of low-permeability shale, siltstone, dolostone, and limestone (Hays and others, 2016).

The Ozark aquifer includes productive dolostone units of the lower Ozark aquifer (median thickness of $885 \mathrm{ft}$ ), denser and relatively lower permeability dolostones of the middle Ozark aquifer (median thickness of $416 \mathrm{ft}$ ), and the mixed lithology of limestone, dolostone, shale, and limited sandstone units of the upper Ozark aquifer (median thickness of $590 \mathrm{ft}$ ) (Hays and others, 2016; Imes and Emmett, 1994; Westerman and others, 2016a) (fig. 2). The lower Ozark aquifer is generally the most productive part of the Ozark aquifer owing to the enhanced secondary and tertiary porosity and permeability from karst formations (Hays and others, 2016). Wells penetrating the Ozark aquifer yield between 50 and 100 gallons per minute $(\mathrm{gal} / \mathrm{min})$, but yield can increase to more than 1,000 gal $/ \mathrm{min}$ where wells penetrate the lower Ozark aquifer (Adamski and others, 1995). The Ozark aquifer is generally unconfined where rocks crop out in the Salem Plateau and confined where overlain by the Ozark confining unit (figs. 1 and 3). The lower Ozark aquifer is broadly confined where overlain by the low-permeability units of the middle Ozark aquifer. The Ozark confining unit is relatively thin (median thickness is $42 \mathrm{ft}$; Westerman and others, 2016a) to absent in some areas, which permits hydraulic connection of the underlying Ozark aquifer and overlying Springfield Plateau aquifer (fig. 2). Lithology of the Ozark confining unit varies throughout the study area, but is generally composed of low-permeability limestone, sandstone, and shale units (Hays and others, 2016).

The uppermost aquifer of the Ozark system is the Springfield Plateau aquifer of Mississippian age, which consists of limestone with varying chert abundance and has a median thickness of $237 \mathrm{ft}$ (Hays and others, 2016; Westerman and others, 2016a). Hydraulic properties vary owing to the variable chert content, fracture networks, and conduits (Hays and others, 2016). Well yields reflect the anisotropic hydraulic properties, such that yields of 10 to $100 \mathrm{gal} / \mathrm{min}$ are observed in more porous and permeable zones compared to yields of less than $2 \mathrm{gal} / \mathrm{min}$ where only primary porosity occurs (Hays and others, 2016; Kresse and others, 2014). The Springfield Plateau aquifer is generally unconfined throughout much of its extent where it crops out in the Springfield Plateau, except where overlain by the Western Interior Plains confining system (fig. 1). 


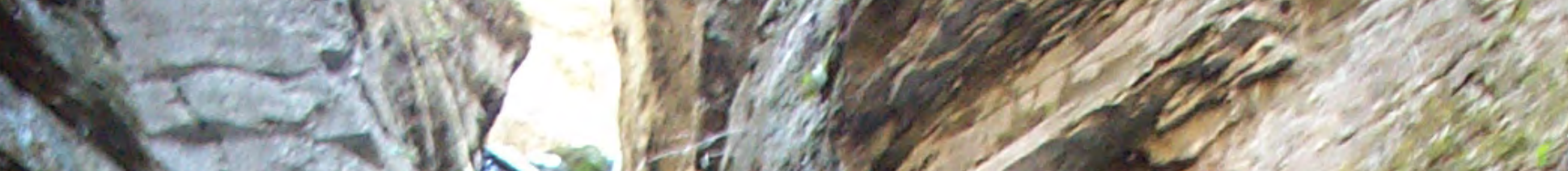

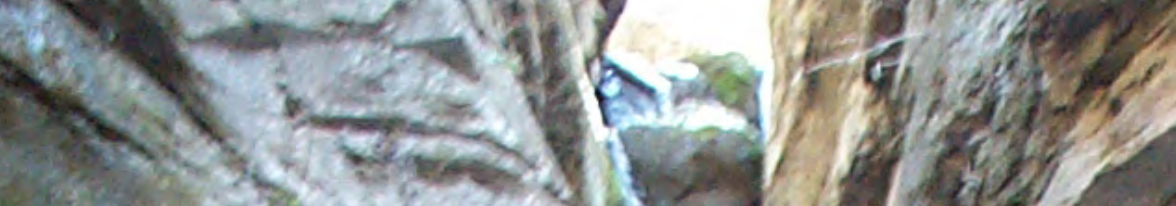

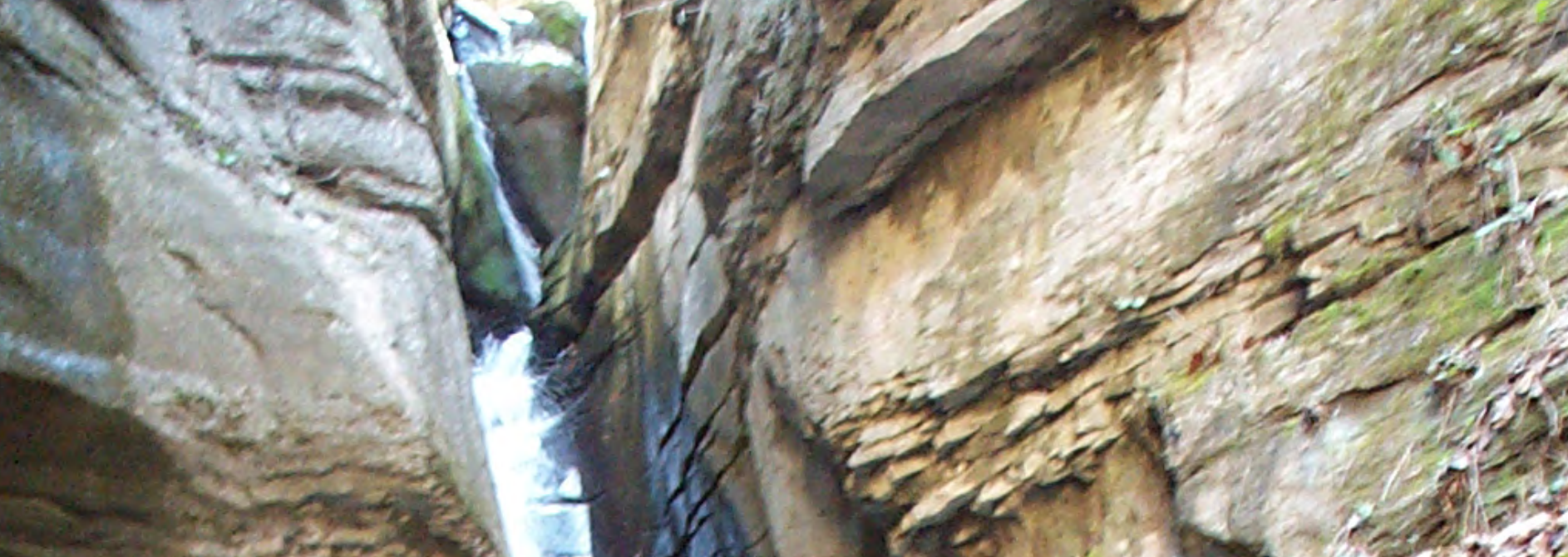

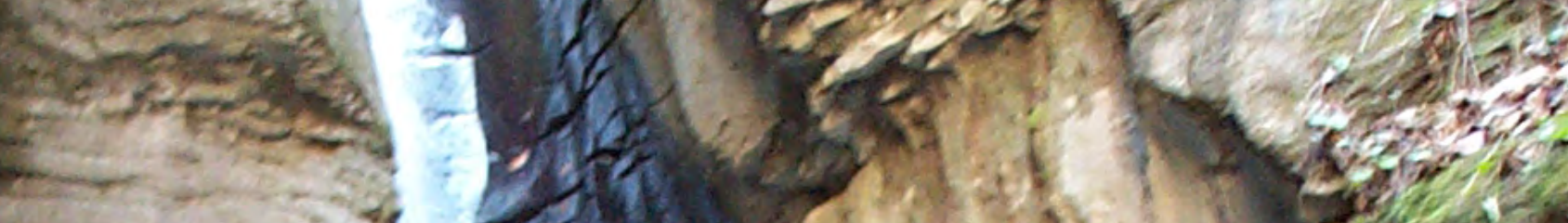

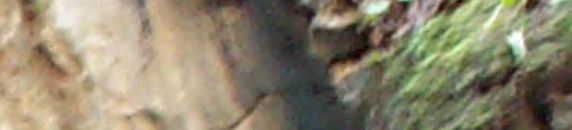




\begin{tabular}{|c|c|c|c|c|c|c|c|c|c|c|}
\hline \multirow[b]{2}{*}{ Era } & \multirow[b]{2}{*}{ System } & \multirow[b]{2}{*}{ Southeastern Missouri } & \multirow[b]{2}{*}{ Southwestern Missouri } & \multirow[b]{2}{*}{ Southeastern Kansas } & \multirow[b]{2}{*}{ Northeastern Oklahoma } & \multirow[b]{2}{*}{ Northern Arkansas } & \multicolumn{3}{|c|}{$\begin{array}{l}\text { Aquifers and confining units } \\
\text { described in the report }\end{array}$} & \multirow[b]{2}{*}{ Model layer } \\
\hline & & & & & & & \multicolumn{3}{|c|}{\begin{tabular}{c|c}
$\begin{array}{c}\text { Hydrogeologic } \\
\text { unit }\end{array}$ & $\begin{array}{c}\text { Hydrogeologic } \\
\text { system }\end{array}$ \\
\end{tabular}} & \\
\hline & & & & & & & & & & \\
\hline \multirow{9}{*}{ 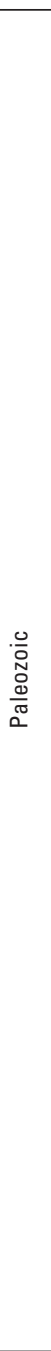 } & 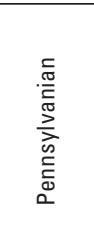 & $\begin{array}{l}\text { Pleasanton Formation } 1 \\
\text { Marmaton Group } 1 \\
\text { Cherokee Group }\end{array}$ & $\begin{array}{l}\text { Kansas City Group } \\
\text { Pleasanton Formation } \\
\text { Marmaton Group } \\
\text { Cherokee Group }\end{array}$ & $\begin{array}{l}\text { Kansas City Group } \\
\text { Pleasanton Group } \\
\text { Marmaton Group } \\
\text { Cherokee Group }\end{array}$ & $\begin{array}{l}\text { Marmaton Group } \\
\text { Cabaniss Group } \\
\text { Krebs Group } \\
\text { Atoka Formation } \\
\text { Bloyd Shale } \\
\text { Hale Formation }\end{array}$ & $\begin{array}{l}\text { McAlester Formation } \\
\text { Hartshorne Sandstone } \\
\text { Atoka Formation } \\
\text { Bloyd Shale } \\
\text { Hale Formation }\end{array}$ & & & 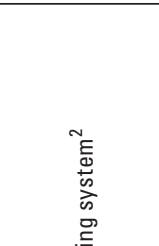 & \\
\hline & \multirow{6}{*}{ 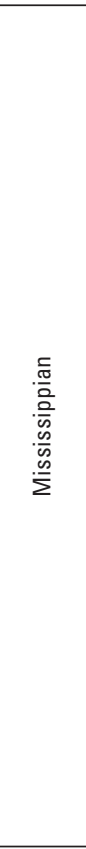 } & \begin{tabular}{|l|} 
Vienna Limestone \\
Tar Springs Sandstone \\
Glen Dean Limestone $e^{1,4}$ \\
Hardinsburg Sandstone \\
Golconda Formation \\
Cypress Formation $^{1,4}$ \\
Paint Creek Formation $^{1,4}$ \\
Yankeetown Sandstone \\
Renault Formation $^{1,4}$ \\
Aux Vases Sandstone $^{1}$
\end{tabular} & $\begin{array}{l}\text { Fayetteville Shale } \\
\text { Batesville Sandstone } \\
\text { Hindsville Limestone } \\
\text { Carterville Formation }\end{array}$ & & \begin{tabular}{|l|} 
Pitkin Limestone \\
\\
$\begin{array}{l}\text { Fayetteville Shale } \\
\text { Batesville Sandstone } \\
\text { Hindsville Limestone }\end{array}$ \\
\end{tabular} & \begin{tabular}{|l|} 
Pitkin Limestone \\
\\
Fayetteville Shale \\
Batesville Sandstone
\end{tabular} & & & 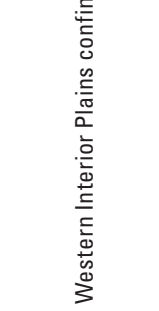 & Layer 1 \\
\hline & & $\begin{array}{l}\text { Ste. Genevieve Limestone }{ }^{3} \\
\text { St. Louis Limestone }\end{array}$ & St. Louis Limestone & St. Louis Limestone & Moorefield Formation & Moorefield Formation & & & & \\
\hline & & $\begin{array}{l}\text { Salem Limestone } \\
\text { Warsaw Limestone }^{3}\end{array}$ & $\begin{array}{l}\text { Salem Limestone } \\
\text { Warsaw Limestone }\end{array}$ & $\begin{array}{l}\text { Salem Limestone } \\
\text { Warsaw Limestone }\end{array}$ & & & \multirow{3}{*}{\multicolumn{2}{|c|}{ 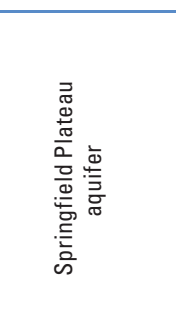 }} & \multirow{6}{*}{ 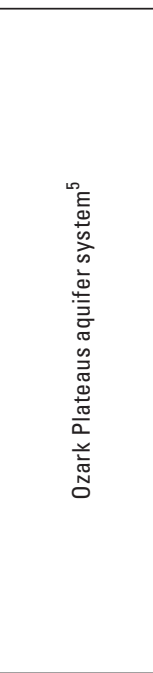 } & \\
\hline & & \begin{tabular}{|l} 
Keokuk Limestone $^{3}$ \\
Burlington Limestone
\end{tabular} & $\begin{array}{l}\text { Keokuk Limestone } \\
\text { Burlington Limestone } \\
\text { Elsey Formation }\end{array}$ & $\begin{array}{l}\text { Keokuk Limestone } \\
\text { Burlington Limestone }\end{array}$ & Keokuk Limestone ${ }^{4}$ & & & & & \\
\hline & & Fern Glen Limestone ${ }^{3}$ & $\begin{array}{l}\text { Reeds Spring Formation } \\
\text { Pierson Formation }\end{array}$ & Fern Glen Limestone & $\begin{array}{l}\text { Boone Formation } \\
\text { Reeds Spring Member } \\
\text { St. Joe Limestone Member }\end{array}$ & \begin{tabular}{|l|} 
Boone Formation \\
Reeds Spring Member \\
St. Joe Limestone Member
\end{tabular} & & & & Layer 2 \\
\hline & & \begin{tabular}{|l|} 
Chouteau Limestone \\
Hannibal Shale \\
Bachelor Formation \\
\end{tabular} & $\begin{array}{l}\text { Northview Shale } \\
\text { Sedalia Limestone } \\
\text { Compton Limestone }\end{array}$ & Chouteau Limestone & $\begin{array}{l}\text { Northview Shale }{ }^{4} \\
\text { Compton Limestone }{ }^{4}\end{array}$ & & \multirow{2}{*}{\multicolumn{2}{|c|}{ 总高 }} & & \\
\hline & \multirow{2}{*}{ 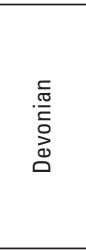 } & $\begin{array}{l}\text { Bushberg Sandstone } \\
\text { Glen Park Limestone } \\
\text { Chattanooga Shale }\end{array}$ & Chattanooga Shale & Chattanooga Shale & $\begin{array}{l}\text { Woodford Shale } \\
\text { Chattanooga Shale }\end{array}$ & Chattanooga Shale & & & & Layer 3 \\
\hline & & $\begin{array}{l}\text { St. Laurent Limestone } \\
\text { Grand Tower Limestone } \\
\text { Clear Creek Chert }{ }^{4} \\
\text { Little Saline Limestone } \\
\text { Bailey Limestone }\end{array}$ & $\begin{array}{l}\text { Callaway Formation }{ }^{4} \\
\text { Fortune Formation }\end{array}$ & & $\begin{array}{l}\text { Sallisaw Formation } \\
\text { Frisco Limestone }\end{array}$ & $\begin{array}{l}\text { Clifty Limestone } \\
\text { Penters Chert }\end{array}$ & $\begin{array}{l}\text { बे } \\
\stackrel{2}{2}\end{array}$ & 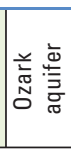 & & Layer 4 \\
\hline
\end{tabular}




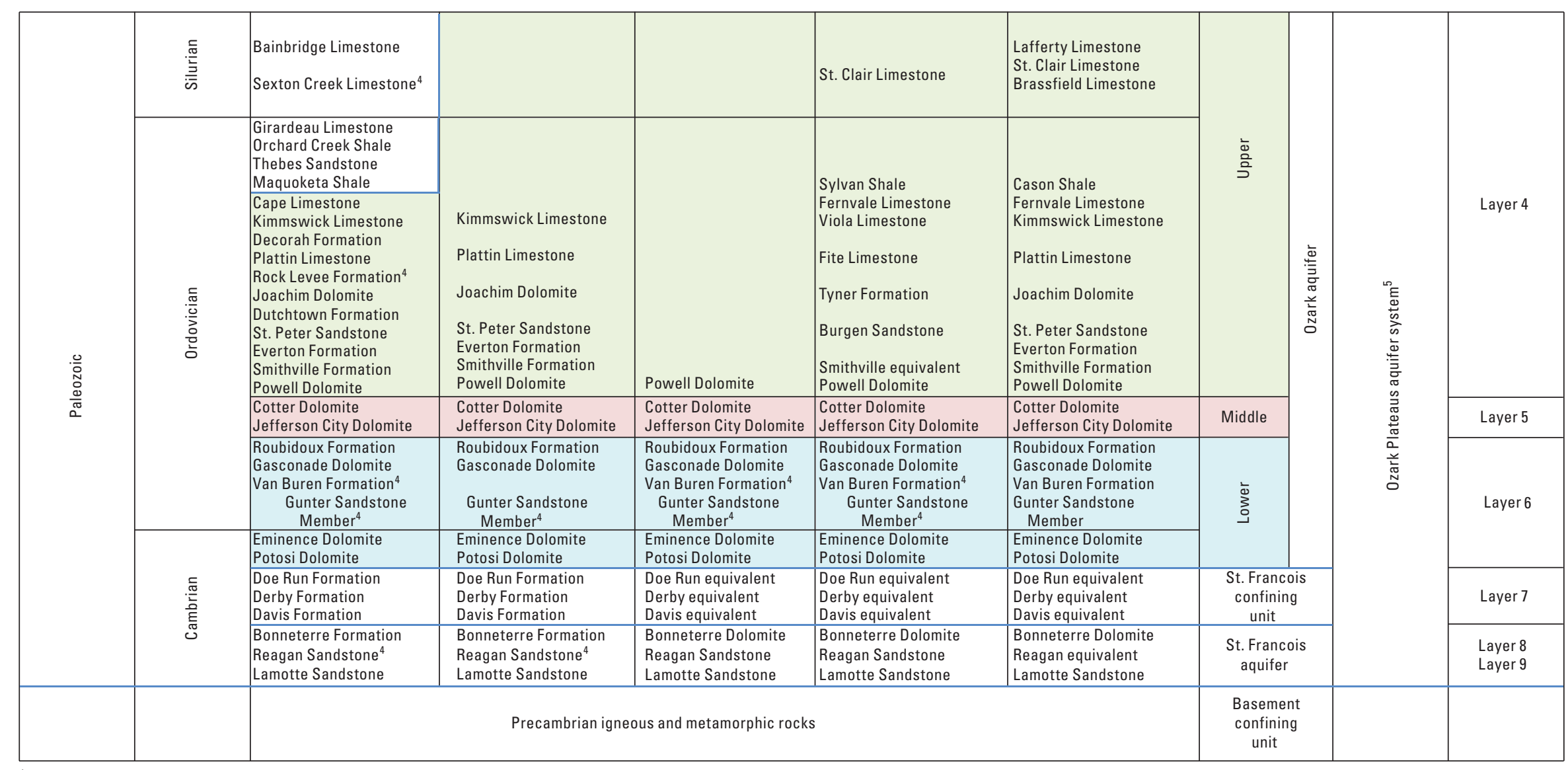

${ }^{1}$ Geologic unit in southeastern Missouri that is stratigraphically equivalent to geologic units in the Western Interior Plains confining system but not part of the confining system.

${ }^{2}$ The Western Interior Plains confining system also includes younger sediments west of the study area.

${ }^{3}$ Geologic unit in southeastern Missouri that is stratigraphically equivalent to geologic units in the Springfield Plateau aquifer but not part of the aquifer.

${ }^{4}$ Unit follows usage of the Missouri Division of Geology and Land Survey, the Kansas Geological Survey, or the Oklahoma Geological Survey.

${ }^{5}$ The Western Interior Plains aquifer system deeply buried in the western part of the study area included where permeable carbonate rocks in the subsurface are equivalents of the aquifers of the Ozark Plateaus aquifer system (Miller and Appel, 1997).

Figure 2. Generalized correlation of Paleozoic-age stratigraphic units, regional hydrogeologic units of the Ozark Plateaus aquifer system, and corresponding model layer numbers (modified from Clark and others, 2018, and Hays and others, 2016). 


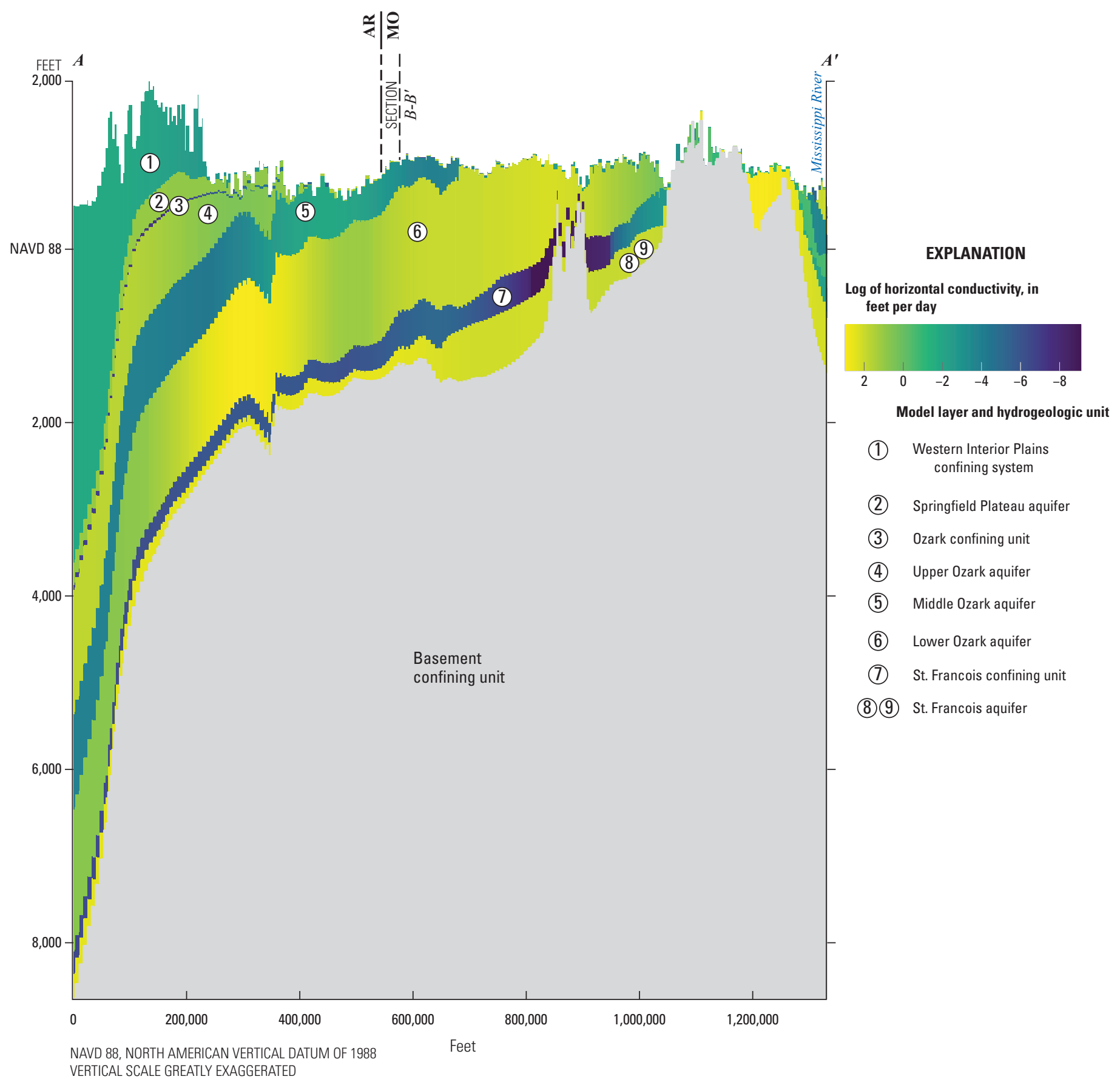

Figure 3. Hydrogeologic units of the Ozark Plateaus aquifer system (Ozark system) using the updated hydrogeologic framework from Westerman and others (2016a, b). $A, A-A^{\prime}$ shows the increased thickness of the Western Interior Plains confining system and dip of Ozark system units towards the southern boundary of the study area. $B, B-B$ 'shows the relation between Ozark system units and Western Interior Plains aquifer system units to the west and post-Paleozoic-age aquifer units to the east. Refer to figure 1 for crosssection locations. 


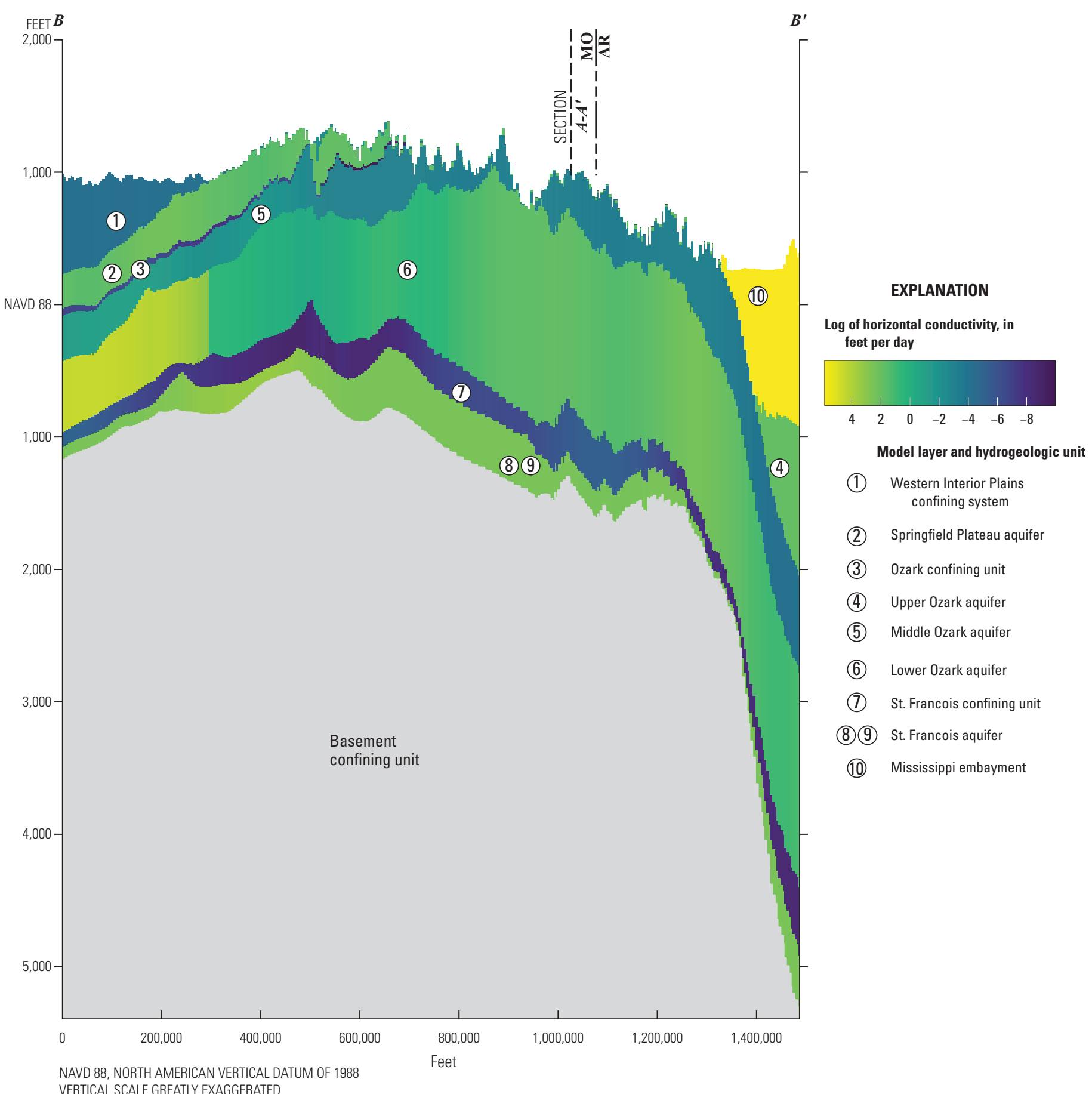

Figure 3. Hydrogeologic units of the Ozark Plateaus aquifer system (Ozark system) using the updated hydrogeologic framework from Westerman and others (2016a, b). $A, A-A^{\prime}$ shows the increased thickness of the Western Interior Plains confining system and dip of Ozark system units towards the southern boundary of the study area. $B, B-B^{\prime}$ shows the relation between Ozark system units and Western Interior Plains aquifer system units to the west and post-Paleozoic-age aquifer units to the east. Refer to figure 1 for crosssection locations.-Continued 
The Ozark system is regionally overlain by the Western Interior Plains confining system in the southern and western extents of the study area (fig. 1). The confining system is mostly composed of shale with lesser amounts of limestone and sandstone. The Western Interior Plains confining system can provide a locally important water supply (especially at shallow depths of less than $300 \mathrm{ft}$ where fracturing and weathering have enhanced porosity and permeability), but yields are generally low such that the unit acts regionally as a confining layer (Jorgensen and others, 1993; Westerman and others, 2016a). The unit has a median thickness of $542 \mathrm{ft}$ in the study area (Westerman and others, 2016a). At the southern boundary of the study area, the Western Interior Plains confining system thickens as underlying units of the Ozark system dip steeply to the south (fig. 3).

Surface water and groundwater flow away from a central axis of uplift, which extends from the Ozark dome (located in the St. Francois Mountains in southeastern Missouri) to the tristate region of southeastern Kansas, southwestern Missouri, and southeastern Oklahoma, outwards towards the boundaries of the study area (Imes and Emmett, 1994; Jorgensen and others, 1996; Nottmeier, 2015). Extensive brittle deformation occurred with uplift (Hudson, 2000) and was followed by periods of dissolution and karst development of carbonate units (Brahana and others, 2009; Hays and others, 2016; Kresse and others, 2014). Karst processes enhanced a network of fractures and faults, creating marked permeability contrasts and aquifer anisotropy that are characteristic of the Ozark system. Primary porosity of aquifers is generally low, and secondary and tertiary porosities related to fractures and dissolution-enlarged conduits provide zones of relatively higher permeability (Hays and others, 2016). Additionally, the groundwater system is connected to surface water through ponors (natural openings in the bottom of a karst sink or basin), losing- and gaining-stream reaches, sinkholes, springs, and caves (Hays and others, 2016; Knierim and others, 2015).

\section{Groundwater Use}

Substantial refinement to USGS county-level groundwater-use estimates for the Ozark system was achieved through compilation and statistical modeling of a site-specific water-use dataset (Knierim and others, 2016, 2017). The USGS has compiled and published a water-use census for the United States every 5 years since 1950 for State-level aggregations and since 1985 for county-level aggregations (U.S. Geological Survey, 2015), but the datasets must be disaggregated to sitespecific locations if groundwater-withdrawal rates are required at a finer scale. The paucity of water-use data prior to the mid1900s was the primary challenge for creating a site-specific groundwater-use record for the Ozark system (Knierim and others, 2017). Groundwater use likely increased in a nonlinear pattern following changes in well-drilling technology, but historical groundwater use was statistically modeled by using a linear extrapolation of groundwater-withdrawal rates from the mid-1900s back to an assumed groundwater-withdrawal rate of 0 million gallons per day (Mgal/d) in 1900 (Knierim and others, 2017). Despite the limitations in available data, the refined water-use record combined site-specific groundwaterwithdrawal rates and USGS county-level groundwater-use estimates into a 111-year dataset that reflected realistic pumping from 1900 through 2010 from the hydrogeologic units that compose the Ozark system (Knierim and others, 2016, 2017). Yearly groundwater-withdrawal rates from Knierim and others $(2016,2017)$ were adjusted during 6-month model stress periods, April through September (representing spring and summer) and October through March (representing fall and winter), to reflect seasonal groundwater use observed by Wittman and others (2003) (Clark and others, 2018).

Groundwater is withdrawn from the Ozark system for public supply, domestic, agricultural (including irrigation and aquaculture), and livestock use and for non-agricultural use (including industrial, thermoelectric power generation, mining, and commercial) (fig. 4B). Groundwater withdrawals totaled approximately $380 \mathrm{Mgal} / \mathrm{d}$ in 2010 (Knierim and others, 2017; U.S. Geological Survey, 2015). The Ozark system provides an important drinking-water supply for people living in the Ozark Plateaus because public supply and domestic use combined constitute the largest groundwater use, totaling $243 \mathrm{Mgal} / \mathrm{d}$ in 2010 , or approximately 64 percent of the total groundwater used that year (fig. 4B) (Knierim and others, 2017). The patterns of groundwater use generally reflect land use across the Ozark Plateaus, which is predominantly forest (48 percent) and agriculture (40 percent), with localized urban development (6 percent) (Hays and others, 2016). Groundwater used for agriculture and livestock totaled approximately $107 \mathrm{Mgal} / \mathrm{d}$ in 2010 (22.4 percent for agriculture and 5.7 percent for livestock, fig. $4 B$ ) and tended to include many relatively smaller withdrawals in hay, pasture, and cropland areas (Knierim and others, 2016, 2017). Non-agricultural use totaled approximately $31 \mathrm{Mgal} / \mathrm{d}$, or approximately 8 percent of the total groundwater use (fig. $4 B$ ) and tended to include relatively larger withdrawals in urban or mining areas (Knierim and others, 2016, 2017). Missouri, the State that covers the most area within the Ozark Plateaus (fig. 1), had the greatest amount of groundwater use in the study area in 2010 (fig. 4A).

In 2010, most groundwater used (55 percent) was withdrawn from the lower Ozark aquifer (fig. $4 C$ ), which also included 57 percent of the wells used for modeling groundwater use (Knierim and others, 2017), and is a regionally important aquifer within the Ozark system (Hays and others, 2016; Imes and Emmett, 1994; Miller and Vandike, 1997). Although each State withdrew groundwater primarily from the lower Ozark aquifer, the proportion varied by region, with the area of Kansas within the Ozark system study area withdrawing the greatest proportion of the State total from the lower Ozark aquifer and Arkansas withdrawing the least (fig. 4E). Groundwater withdrawals were second highest from the middle Ozark aquifer (20.9 percent of the total, fig. 4C), with larger proportions of withdrawals in Missouri (22.2 percent of the State total, fig. $4 E$ ) and Arkansas (17.1 percent of the State total, fig. $4 E$ ). 


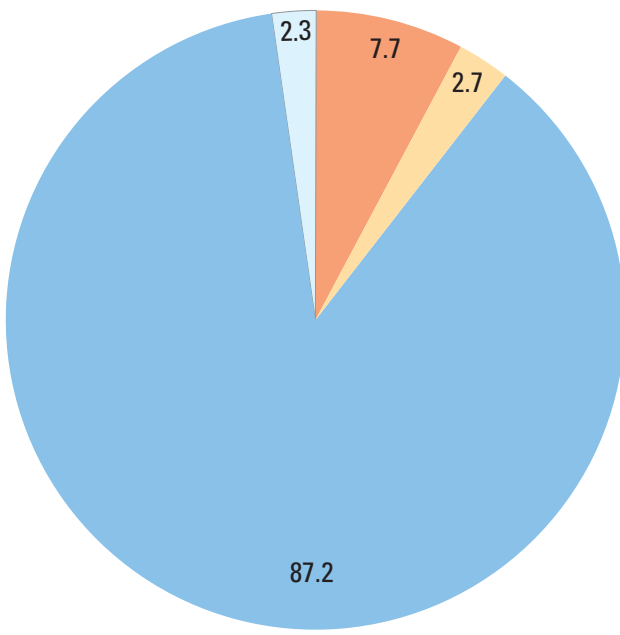

EXPLANATION

Arkansas

Kansas

Missouri

Oklahoma
B

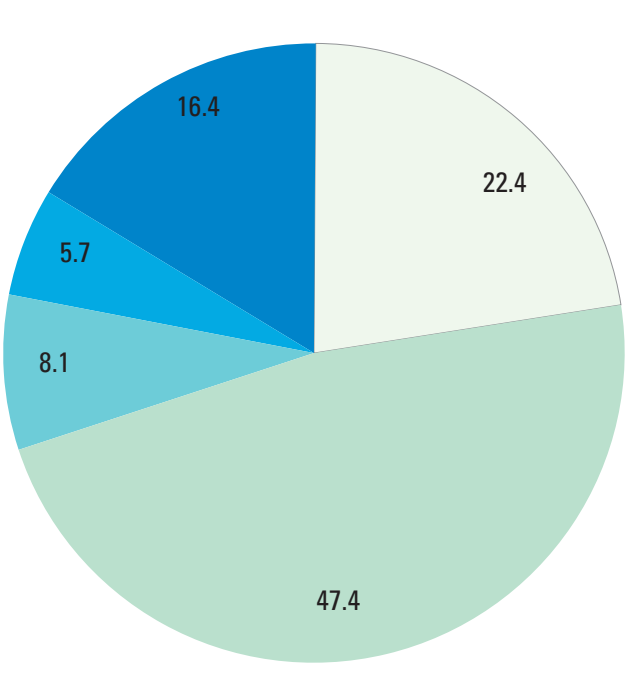

EXPLANATION

Agriculture

Domestic

Livestock

Non-agriculture

Public supply c

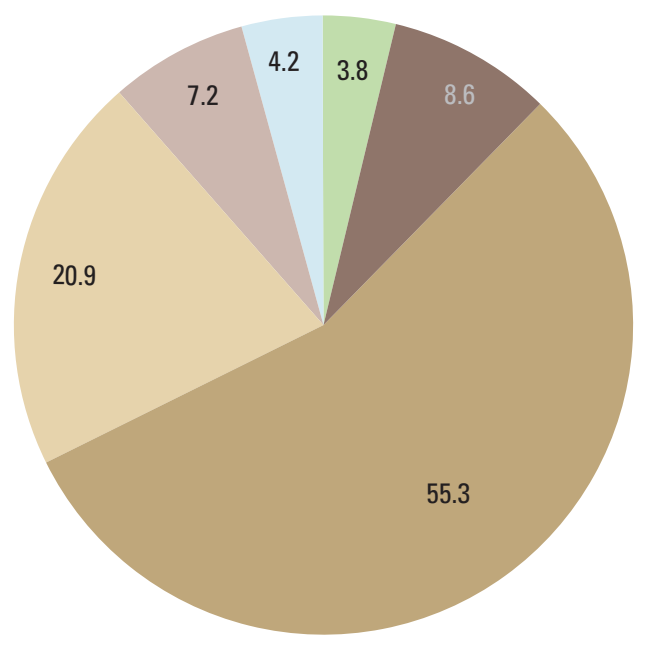

EXPLANATION

Western Interior Plains confining system, model layer 1 Springfield Plateau aquifer, model layer 2

Upper Ozark aquifer, model layer 4

Middle Ozark aquifer, model layer 5

Lower Ozark aquifer, model layer 6

St. Francois aquifer, model layers 8 and 9

Figure 4. Modeled groundwater use in 2010 from the Ozark Plateaus aquifer system by $A$, State, $B$, water-use division, and $C$, hydrogeologic unit and model layer. Water use is also shown for each State in the study area by $D$, water-use division and $E$, hydrogeologic unit and model layer. Groundwater-withdrawal rates from Knierim and others (2016); explanation of methods available from Knierim and others (2017). 
Arkansas

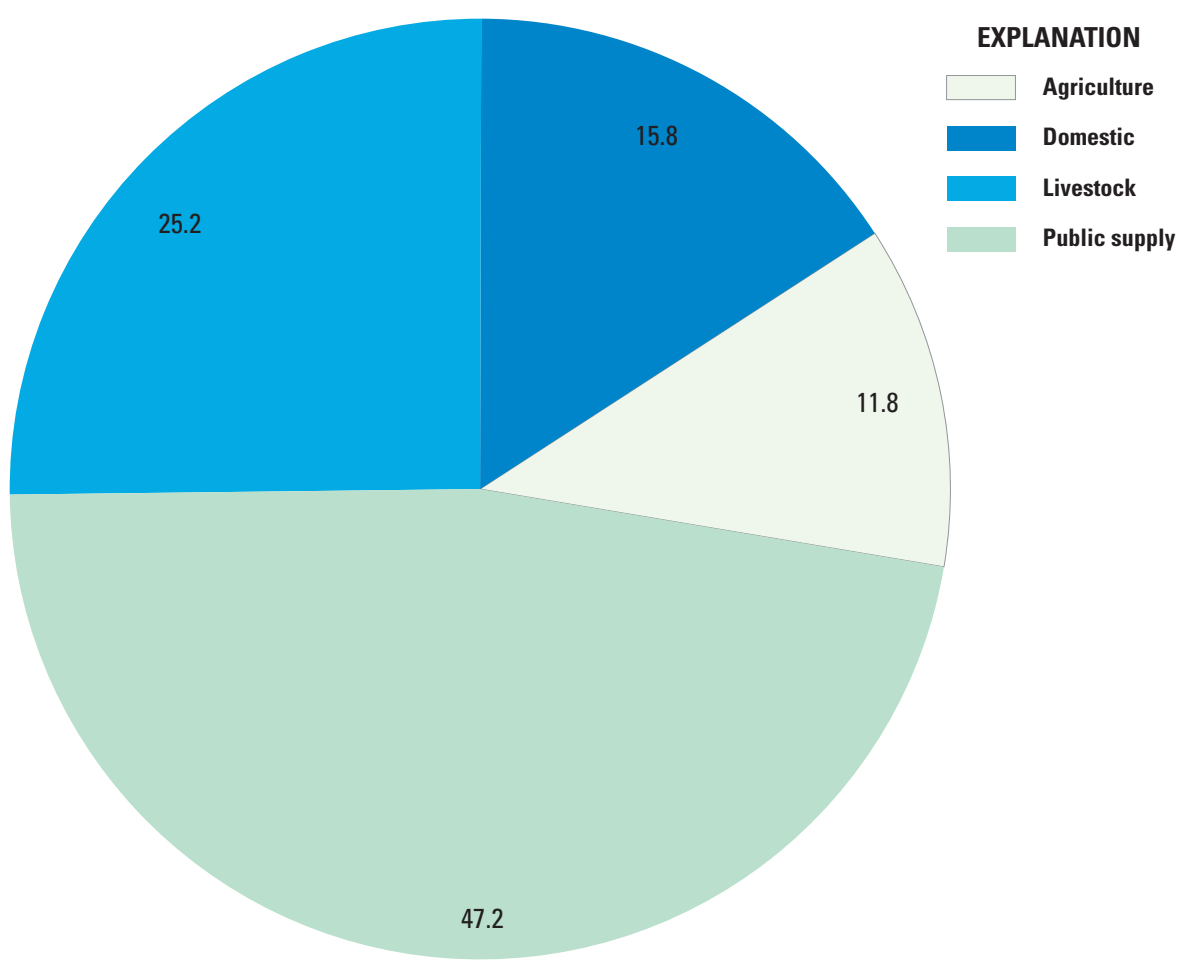

Kansas

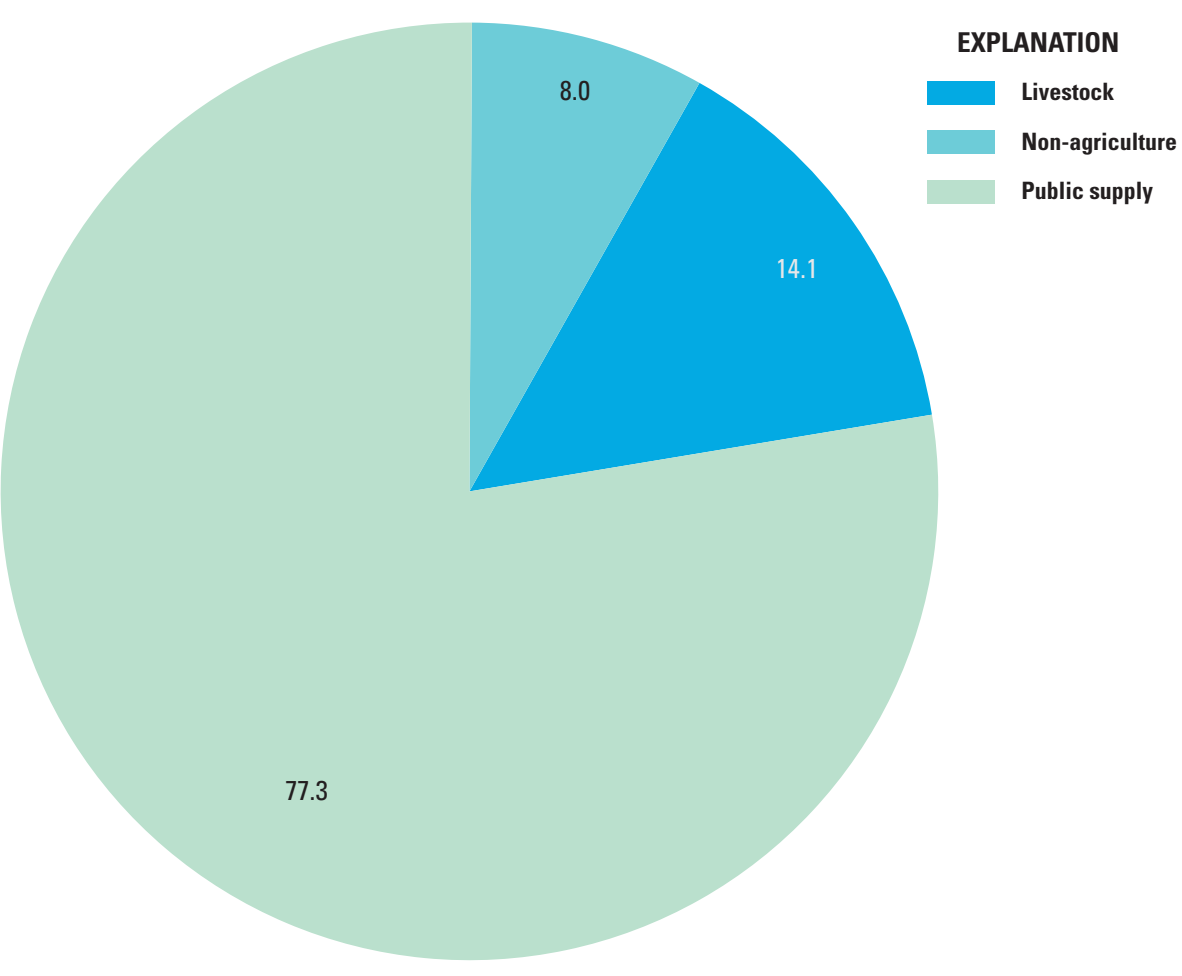

Figure 4. Modeled groundwater use in 2010 from the Ozark Plateaus aquifer system by $A$, State, $B$, water-use division, and $C$, hydrogeologic unit and model layer. Water use is also shown for each State in the study area by $D$, water-use division and $E$, hydrogeologic unit and model layer. Groundwater-withdrawal rates from Knierim and others (2016); explanation of methods available from Knierim and others (2017).-Continued 
D. Continued Missouri
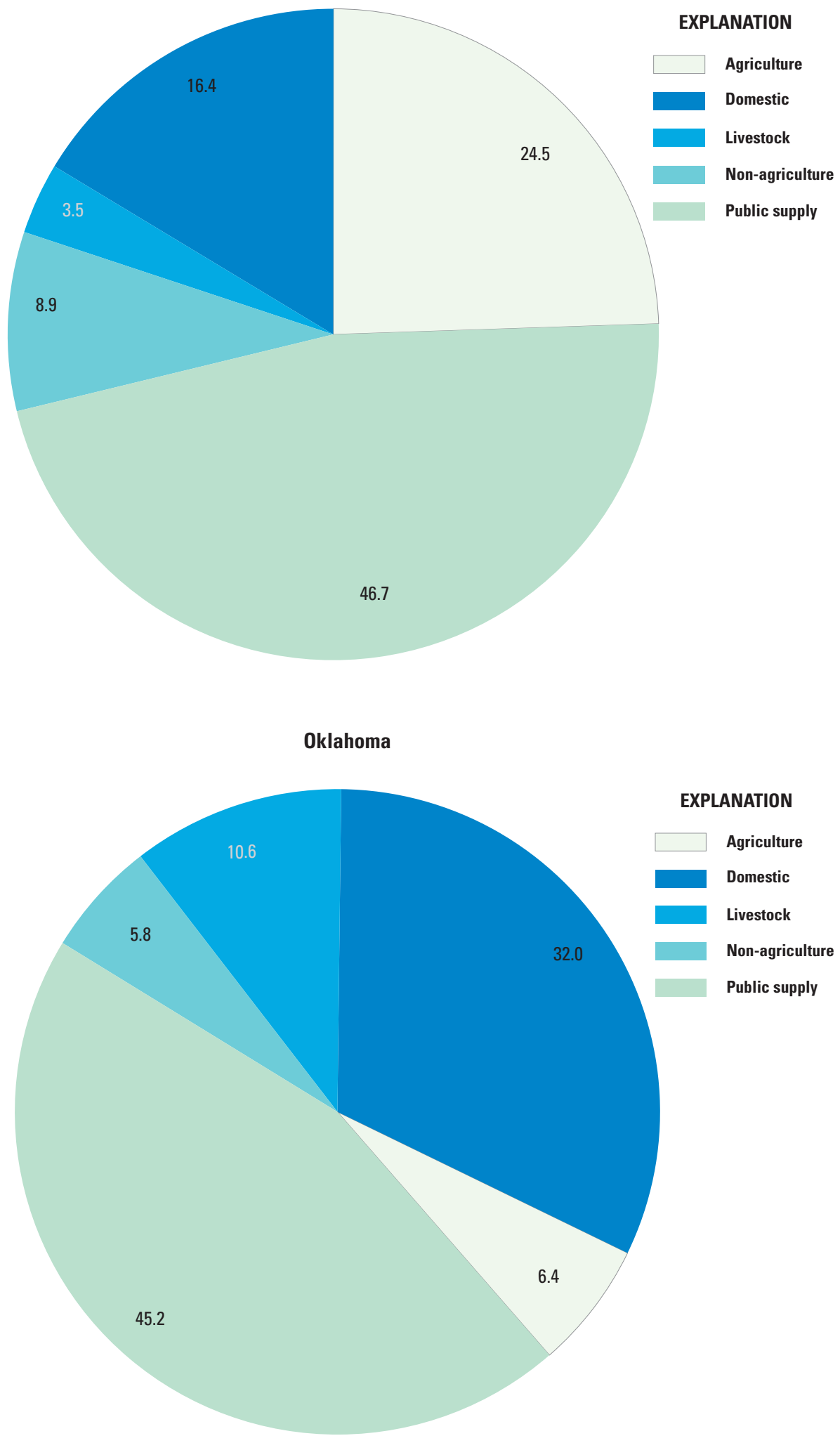

Figure 4. Modeled groundwater use in 2010 from the Ozark Plateaus aquifer system by $A$, State, $B$, water-use division, and $C$, hydrogeologic unit and model layer. Water use is also shown for each State in the study area by $D$, water-use division and $E$, hydrogeologic unit and model layer. Groundwater-withdrawal rates from Knierim and others (2016); explanation of methods available from Knierim and others (2017).-Continued 
Arkansas

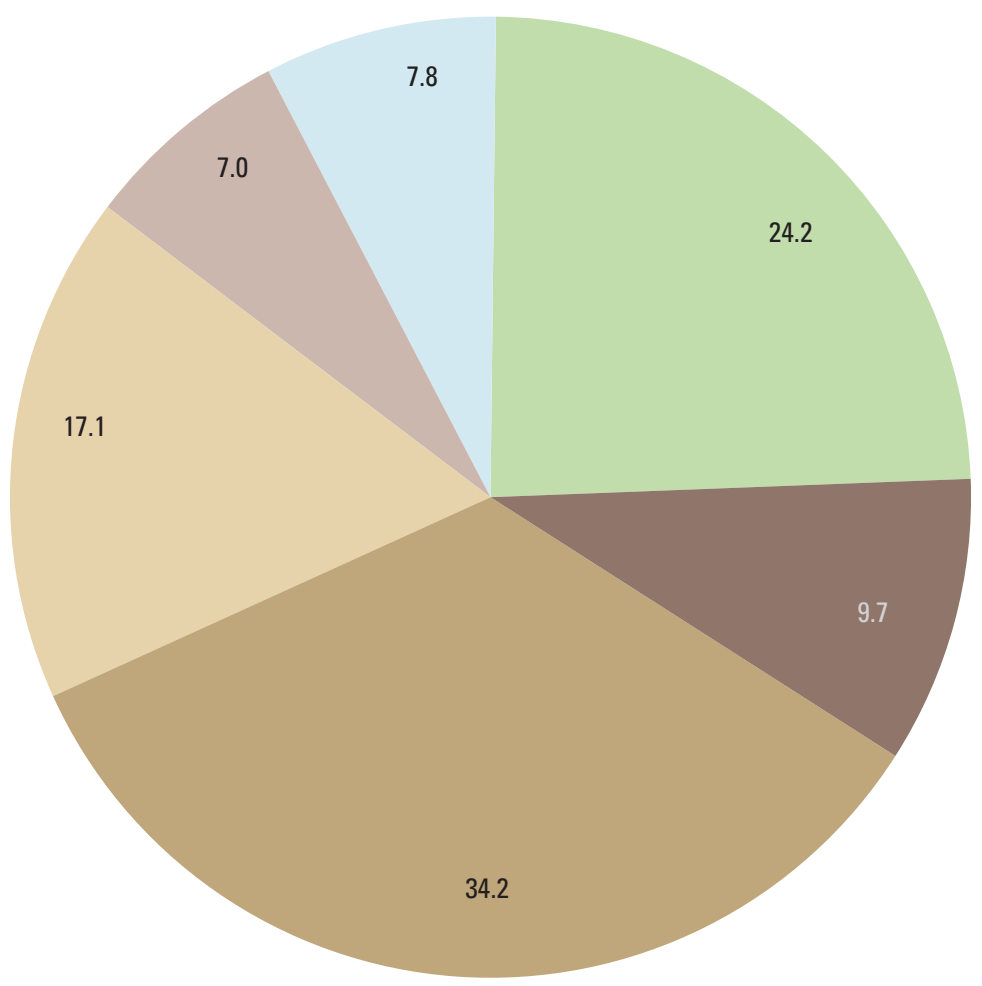

EXPLANATION

Western Interior Plains confining system, model layer 1

Springfield Plateau aquifer, model layer 2

Upper Ozark aquifer, model layer 4

Middle Ozark aquifer, model layer 5

Lower Ozark aquifer, model layer 6

St. Francois aquifer, model layers 8 and 9

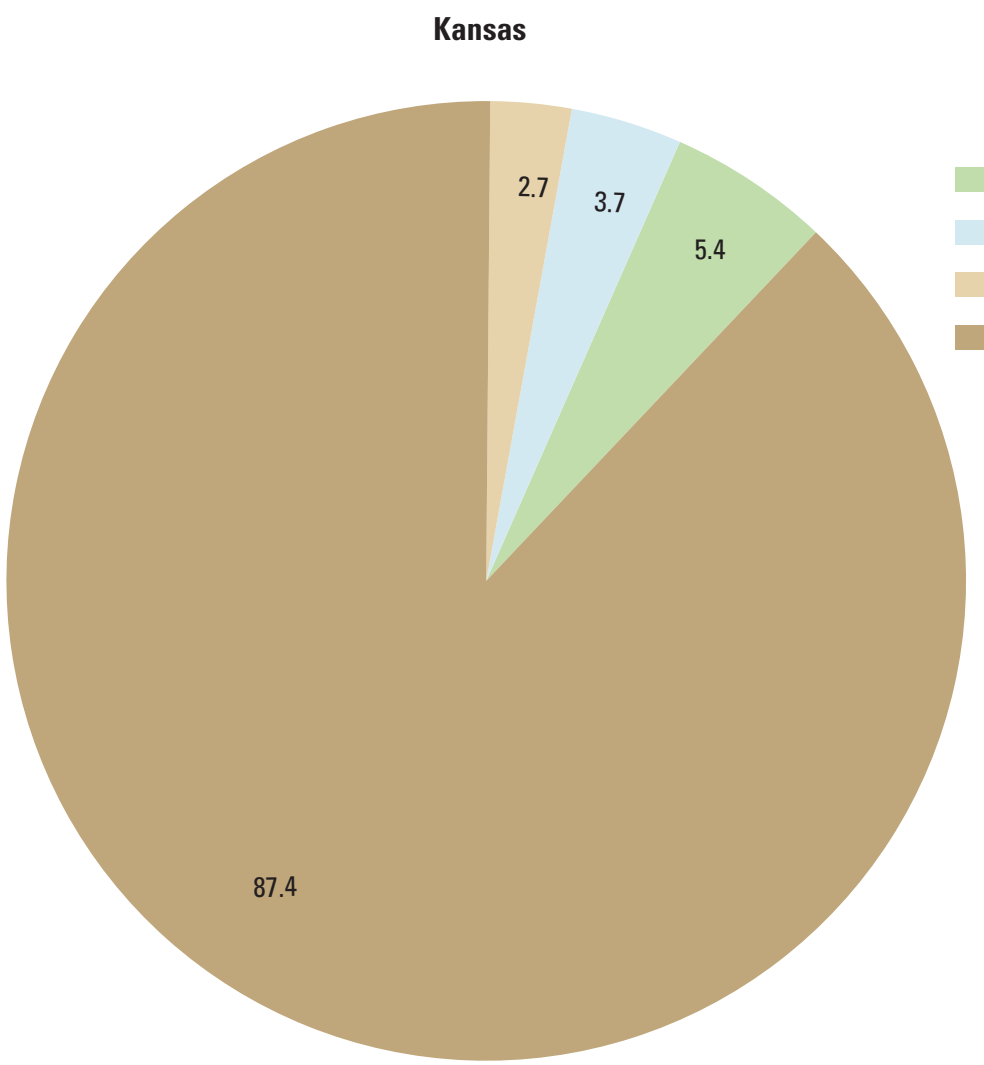

\section{EXPLANATION}

Western Interior Plains confining system, model layer 1

Springfield Plateau aquifer, model layer 2

Middle Ozark aquifer, model layer 5

Lower Ozark aquifer, model layer 6

Figure 4. Modeled groundwater use in 2010 from the Ozark Plateaus aquifer system by $A$, State, $B$, water-use division, and $C$, hydrogeologic unit and model layer. Water use is also shown for each State in the study area by $D$, water-use division and E, hydrogeologic unit and model layer. Groundwater-withdrawal rates from Knierim and others (2016); explanation of methods available from Knierim and others (2017). - Continued 
E. Continued

Missouri

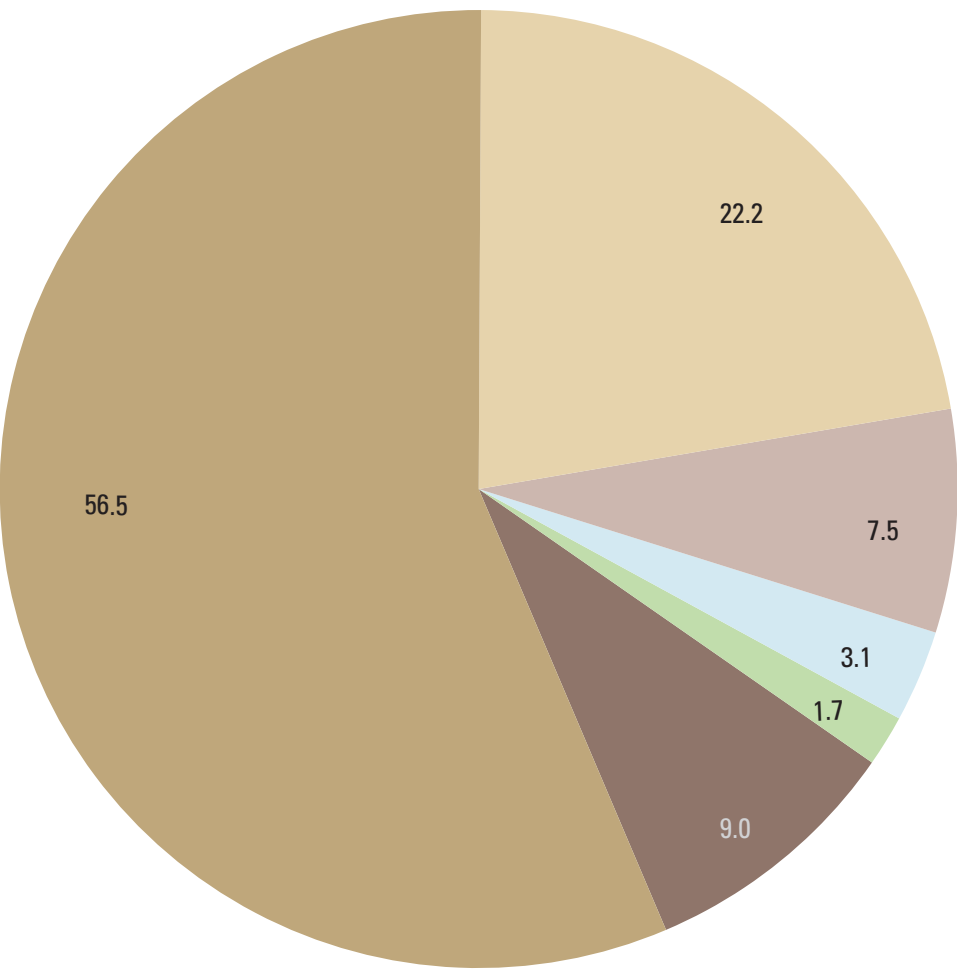

Oklahoma

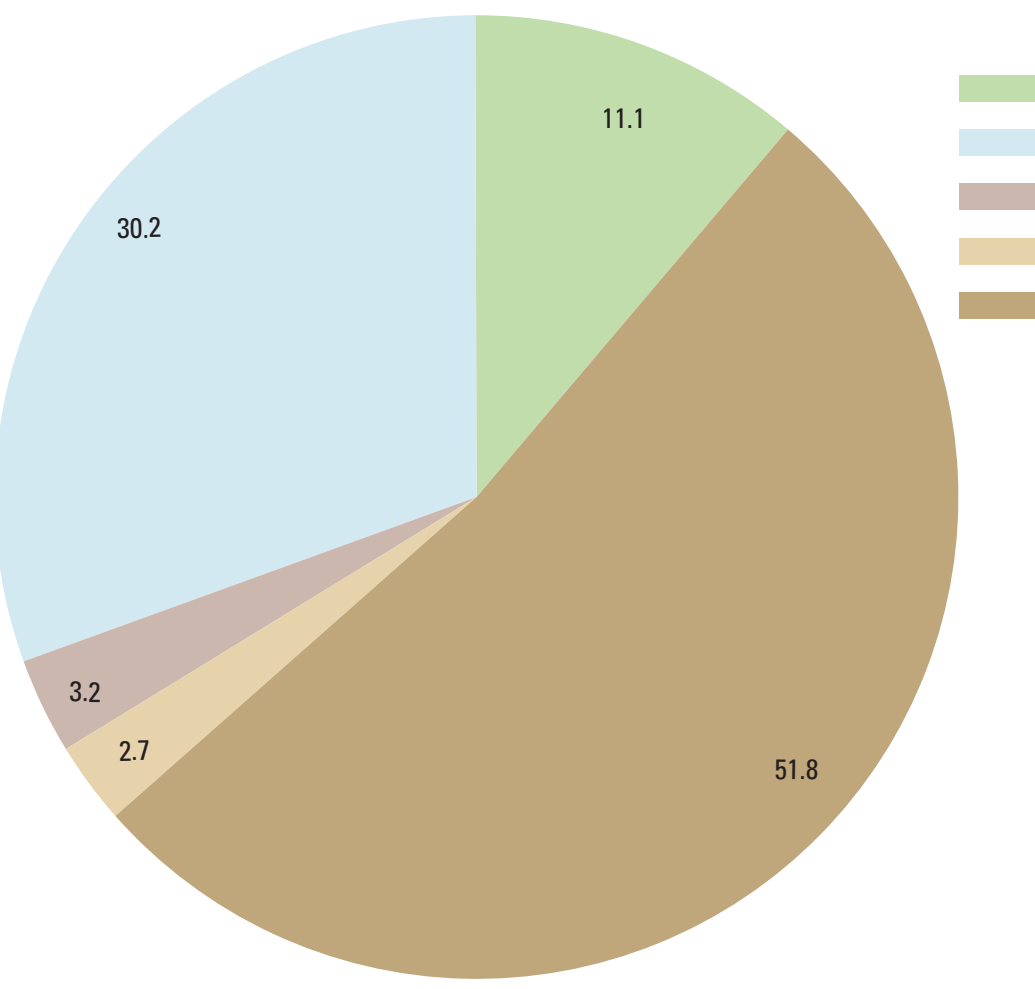

\section{EXPLANATION}

Western Interior Plains confining system, model layer 1

Springfield Plateau aquifer, model layer 2

Upper Ozark aquifer, model layer 4

Middle Ozark aquifer, model layer 5

Lower Ozark aquifer, model layer 6

St. Francois aquifer, model layers 8 and 9

\section{EXPLANATION}

Western Interior Plains confining system, model layer 1 Springfield Plateau aquifer, model layer 2

Upper Ozark aquifer, model layer 4

Middle Ozark aquifer, model layer 5

Lower Ozark aquifer, model layer 6

Figure 4. Modeled groundwater use in 2010 from the Ozark Plateaus aquifer system by $A$, State, $B$, water-use division, and $C$, hydrogeologic unit and model layer. Water use is also shown for each State in the study area by $D$, water-use division and $E$, hydrogeologic unit and model layer. Groundwater-withdrawal rates from Knierim and others (2016); explanation of methods available from Knierim and others (2017)._- Continued 
The middle Ozark aquifer was previously conceptualized as a confining unit owing to low-permeability dolostone (Hays and others, 2016); however, the calibrated groundwater-flow model included horizontal conductance values within the same range as those of the upper Ozark aquifer (Clark and others, 2018), and groundwater use was second only to the lower Ozark aquifer (fig. 4C). The middle Ozark aquifer therefore serves as an important groundwater resource, despite lower permeability than some of the more karstified units such as the Springfield Plateau aquifer or the lower Ozark aquifer.

The statistically modeled site-specific water-use record had a relatively high uncertainty of 38 percent based on nonlinear statistical methods (Knierim and others, 2017). Similar to other groundwater-flow models, water use remains a challenging component of the hydrologic budget (Clark and others, 2013), but is of paramount importance to better quantify the availability of water resources. Of particular challenge in the Ozark system, groundwater use is a small component of the regional hydrologic budget (Hays and others, 2016), but groundwater withdrawals from carbonate units with low primary porosity and storage can create steep, localized cones of depression around pumping centers (Richards, 2010). Therefore, correctly locating pumping wells within model cells can be difficult and affects the position and magnitude of modeled drawdown.

\section{Methods}

The Ozark groundwater-flow model version 1.0 (v1.0) (Clark and others, 2018), also archived in Duncan and others (2018) has been modified for this report, hereinafter referred to as model version 1.1 (v1.1) and archived in Duncan and others (2019). The model v1.1 was created to evaluate the conceptual groundwater flow of predevelopment and changes in postdevelopment groundwater flow, effects of climate variability, and a groundwater monitoring network. The scenarios described in this report extend the model simulation through September 2060 and use forecasted precipitation based on multiple global circulation models and increases in pumping based on historical trends. The model v1.1 was used to evaluate existing monitoring wells as an example of data-worth analysis through the use of model prediction uncertainty (Doherty, 2016; Fienen and others, 2010), as implemented in PEST++ (Welter and others, 2015; White and others, 2015). Such monitoring networks are critical indicators of current, past, and future conditions of a groundwater resource.

\section{Data Compilation}

Data compilation for construction of the numerical groundwater-flow model used in this report began in 2013 (Clark and others, 2018). Data compilation efforts were focused on six main components: (1) the hydrogeologic framework, (2) groundwater pumpage (water use), (3) hydraulic-head observations, (4) surface-water flows, (5) aquifer properties, and (6) net recharge. The database of information used to construct the hydrogeologic framework represented in model v1.0 and v1.1 includes lithologic, geophysical, driller description, and well-cutting logs (Westerman and others, 2016a, b). Groundwater-pumpage data included reported, estimated, and trend analysis of groundwater pumpage for as much as 100 years of data distributed to more than 140,000 groundwater-well locations (Knierim and others, 2017). Hydraulic-head data for model v1.0 and v1.1 consisted of more than 19,000 groundwater-level altitudes from the USGS National Water Information System (USGS, 2015). Computation of streamflow or stream-seepage values were evaluated from 81 named streams (Clark and others, 2018; Knierim and others, 2015). Aquifer properties for each hydrogeologic unit were evaluated based on available aquifer test information, literature values for similar hydrogeologic units, or previous groundwater-model studies. Net recharge to the outcrop areas of all hydrogeologic units was assigned initially through use of the Soil-Water-Balance (SWB) model (Westenbroek and others, 2010), augmented by estimates from the Empirical Water Balance method (Reitz and others, 2015, 2017), and refined through model calibration.

\section{Numerical Model}

A transient groundwater model v1.1 was developed for the Ozark system by using the modular three-dimensional finite-difference MODFLOW-NWT code (Niswonger and others, 2011) and calibrated by using PEST++ (Welter and others, 2015). The model consists of horizontally uniform $1-\mathrm{mi}^{2}$ cells of variable thickness. The finite-difference grid is oriented north-south and consists of 324 rows, 335 columns, and 9 layers. Hydraulic properties, such as conductivity and storage, vary by model cells areally and vertically to represent changes in aquifer properties owing to lithology (table 1.1 in appendix 1). The model simulates 116 years (January 1, 1900 to April 1, 2016) of system response divided into 79 stress periods to quantify groundwater resources, evaluate how groundwater resources have changed over time, and forecast the responses of the aquifer system to future stresses. The latter 50 stress periods, beginning around 1991, represent seasonal changes in recharge and pumping. As previously noted, these seasonal effects are important at local scales where short-term drought can result in large groundwaterlevel declines that are of concern to water managers.

The digital archive of the model includes an additional stress period at the end of the calibration period. This stress period is simulated as steady state and was included for preliminary evaluation of forecast uncertainty in model v1.0 (Clark and others, 2018), prior to development of the three scenarios used to quantify parameter and predictive uncertainty and data-worth and that are presented herein. The final stress period and associated forecast observations, therefore, are not included as part of this report. 
Ozark system boundaries were represented as no-flow, general-head, or constant-head boundaries (fig. 1), depending on knowledge about groundwater interaction among adjacent systems. The top of the Basement confining unit is the lower boundary of the model and is represented as a no-flow boundary because the Basement confining unit generally has permeability that is orders of magnitude lower than that of the overlying aquifer system. Most boundaries at the edges of the study area were also represented as no-flow boundaries (fig. 1). Seepage-run studies indicate that the Ozark system loses groundwater to surface water (Knierim and others, 2015). Streams, therefore, are important hydrologic features in this system and were represented as head-dependent flux boundaries in the model by using the River Package (Harbaugh, 2005); streams generally serve as net sinks, or losses of water, from the Ozark system. Groundwater flow to and from adjacent systems is represented as a general-head boundary towards the southeastern part of the study area (fig. 1) (where groundwater exchanges between the Ozark system and Cretaceous- and Tertiary-age units of the Mississippi embayment), and is represented as a constant-head boundary at the western part of the study area (fig. 1) (where fresh and saline water mix at the freshwater-saltwater transition zone).

The western boundary coincides with a topographic lowland that is influenced by salt water from the Western Interior Plains aquifer system. The dense saltwater plunges beneath the freshwater flowing out from the study area, and mixing of freshwater and saltwater occurs at the western margins of the Ozark system as evidenced by saline springs, streams, and groundwater (Hays and others, 2016). The freshwater-saltwater transition zone along the western extent of the study area (fig. 1) is not modeled explicitly, but is represented as a constant-head boundary (additional detail in Clark and others, 2018) to allow indirect assessment of groundwater flow across the interface.

\section{Modifications to the Numerical Model}

Model v1.1 is a modified version of model v1.0, documented by Clark and others (2018) and Duncan and others (2018) to improve the simulation of groundwater flow. The datasets for the modified model v1.1 can be found online (Duncan and others, 2019). These adjustments to model v1.0 included increased density of pilot points in selected areas and more rigorous parameter estimation through focused observation weighting and extended iterations with PEST++. Because of the distribution of pumping stresses affecting local areas of interest, the density of pilot points was increased from a spacing of 15 miles (mi) to $3 \mathrm{mi}$ in areas of Springfield, Joplin, and Noel, Mo., and Miami, Okla. (fig. 1). Head observations in central Missouri and Oklahoma collected after 1995 were given a higher weight than other observations. The parameter estimation process was also allowed to progress further than during previous attempts after it was recognized that nonlinear parameter derivatives may have been affecting the ability of PEST ++ to properly calculate the optimal set of parameters. These modifications produced a better fit to head and streamflow leakage observations, though some parameter values were forced beyond the range of what is thought to be reasonable values for the system. These parameters were manually adjusted to lie within a range of more reasonable values (based on aquifer properties), without substantially adversely affecting the fit to observed values.

Additional manual changes included replacing aquifer properties in layer 1 in the northern part of the Mississippi embayment and reducing recharge in stress periods 2 and 3. In model v1.0 (Clark and others, 2018), an area north of the embayment represents the Western Interior Plains confining system. In model v1.1, it was decided that much of that area would be better represented as part of the embayment. Recharge was reduced in stress periods 2 and 3 by setting it equal to the stress period 1 rate to better align with the conceptual understanding of the system. Without this reduction, storage would have increased in the system from 1900 to 1965 resulting in a slight rise in water levels, likely the result of early, lesser quality observations influencing the recharge parameters.

Two of the more substantive changes were made to the hydraulic conductivity values of the Springfield Plateau and lower Ozark aquifers (fig. 5). The maximum horizontal hydraulic conductivity of the Springfield Plateau aquifer increased from 6.48 to 191 feet per day $(\mathrm{ft} / \mathrm{d})$ in northeastern Oklahoma. Though this value appears high compared to the horizontal hydraulic conductivity values for the rest of the aquifer, northeastern Oklahoma is an area of intense mining that modified the aquifer structure, thereby changing the aquifer properties of the unit and greatly increasing the permeability on a local scale (Czarnecki and others, 2009). The maximum horizontal hydraulic conductivity of the lower Ozark aquifer increased to $93 \mathrm{ft} / \mathrm{d}$ in eastern Kansas. The changes in Kansas were driven completely by the automated parameter estimation procedure, yet the higher hydraulic conductivity values appear to correspond with previous evidence of higher transmissivity values in the area (Macfarlane and others, 2005; Reed and Burnett, 1985).

Simulated heads were generally in good agreement with observed hydraulic heads, with 66 percent of simulated values within $60 \mathrm{ft}$ of the observed value, which is about 2 percent of the total range in head $(2,578 \mathrm{ft})$. Simulated heads were computed for 19,044 observed hydraulic-head measurements from 6,682 wells within the Ozark model area. Values of mean, minimum, maximum, root mean square error (RMSE), and mean absolute error were computed from residuals for each year from 1900 through 2013 (table 1). RMSE, in feet, is determined by using the equation

$$
R M S E=\frac{\sqrt{\left(h_{o}-h_{s}\right)^{2}}}{n}
$$

where

$h_{o} \quad$ is observed hydraulic head, in feet;

$h_{s} \quad$ is simulated hydraulic head, in feet; and

$n \quad$ is number of observations. 
Springfield Plateau aquifer, model layer 2

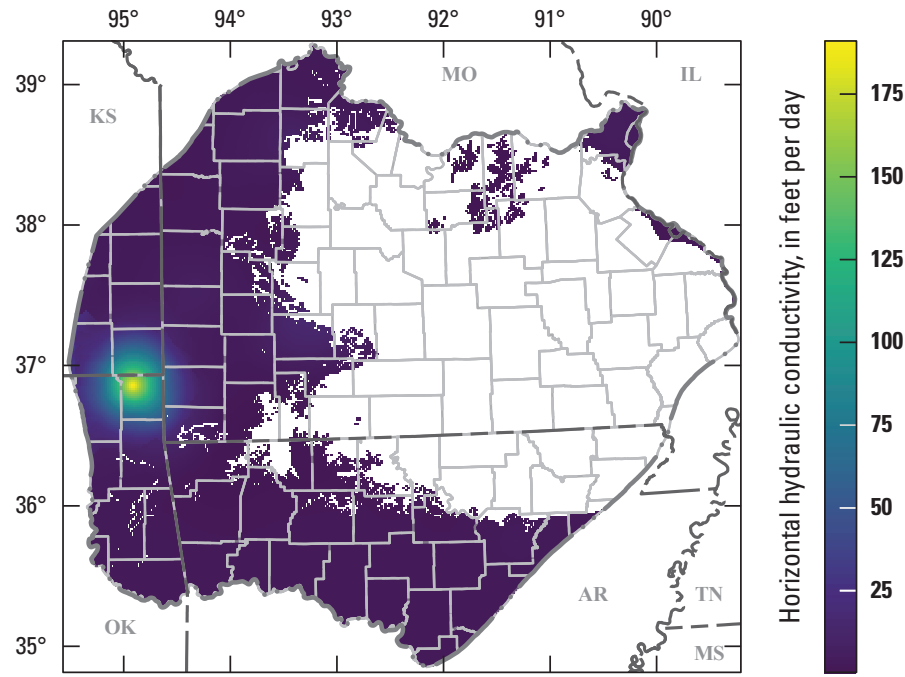

Lower Ozark aquifer, model layer 6

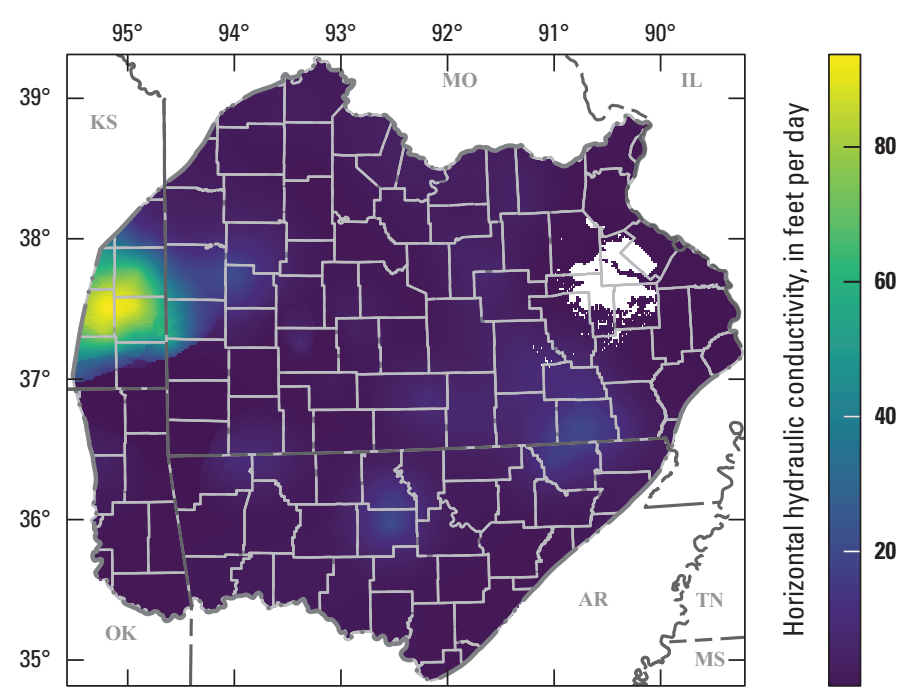

Note: White areas inside the study area boundary indicate unit not present
Upper Ozark aquifer, model layer 4
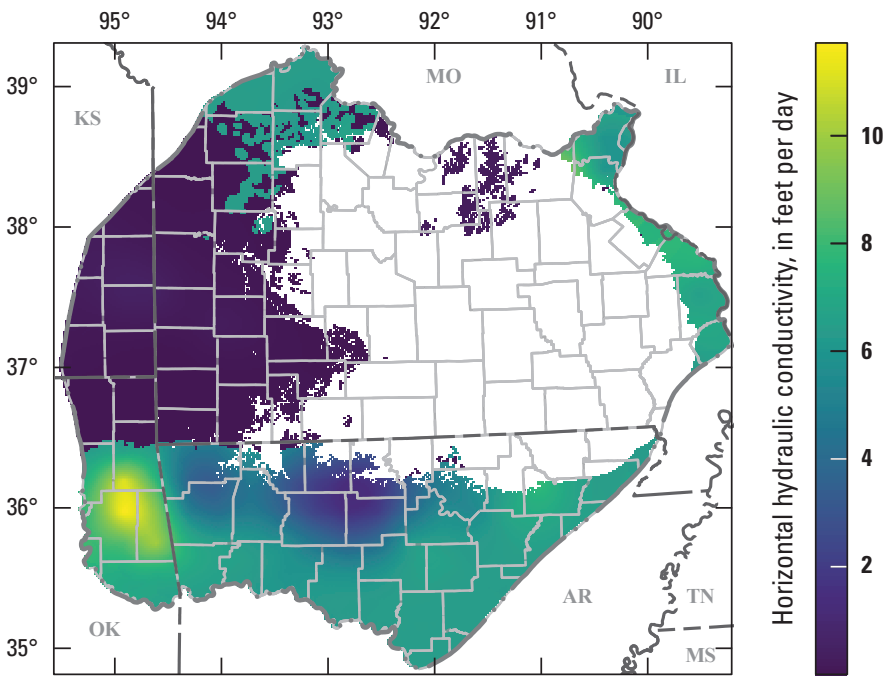

St. Francois aquifer, model layers 8 and 9

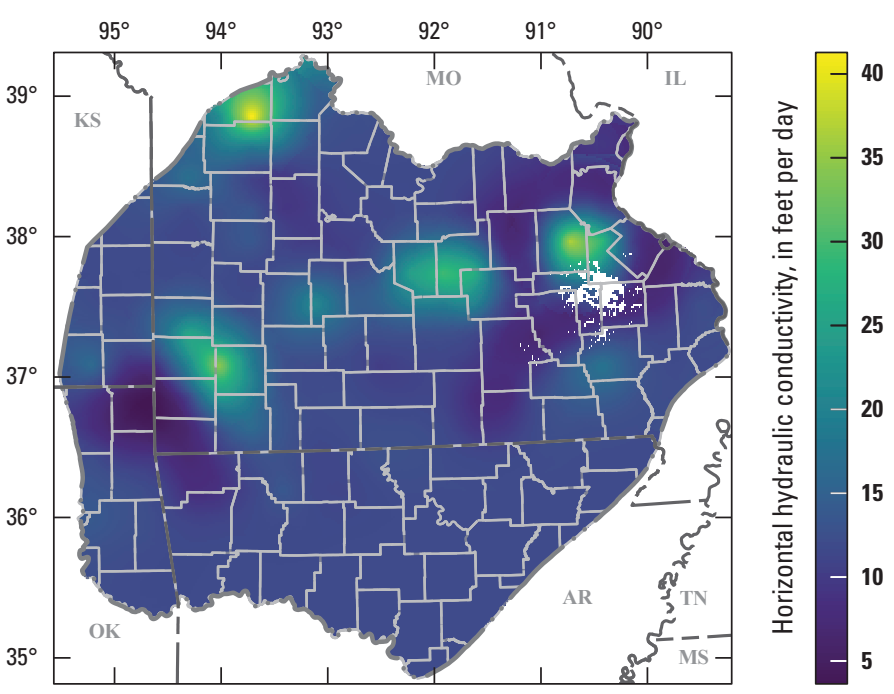

Figure 5. Horizontal hydraulic conductivity of select model layers within the Ozark model area. 
Table 1. Summary of hydraulic-head residual statistics for calibration of the Ozark groundwater-flow model, version 1.1.

[RMSE, root mean square error; - , no value]

\begin{tabular}{|c|c|c|c|c|c|c|c|c|}
\hline Year & $\begin{array}{l}\text { Mean, } \\
\text { in feet }\end{array}$ & $\begin{array}{c}\text { Minimum } \\
\text { residual, } \\
\text { in feet }\end{array}$ & $\begin{array}{c}\text { Maximum } \\
\text { residual, } \\
\text { in feet }\end{array}$ & $\begin{array}{l}\text { RMSE, } \\
\text { in feet }\end{array}$ & $\begin{array}{c}\text { Mean } \\
\text { absolute error, } \\
\text { in feet }\end{array}$ & $\begin{array}{c}\text { Number of } \\
\text { observations }\end{array}$ & $\begin{array}{l}\text { Range, } \\
\text { in feet }\end{array}$ & $\begin{array}{c}\text { Ratio of } \\
\text { RMSE } \\
\text { to range } \\
\end{array}$ \\
\hline 1900 & 2 & 2 & 2 & 2 & 2 & 1 & 0 & - \\
\hline 1905 & -46 & -109 & -6 & 64 & 46 & 3 & 580 & 0.11 \\
\hline 1906 & -62 & -62 & -62 & 62 & 62 & 1 & 0 & - \\
\hline 1907 & -17 & -96 & 62 & 81 & 79 & 2 & 7 & 11.53 \\
\hline 1908 & -21 & -21 & -21 & 21 & 21 & 1 & 0 & - \\
\hline 1910 & -16 & -16 & -16 & 16 & 16 & 1 & 0 & - \\
\hline 1911 & -22 & -22 & -22 & 22 & 22 & 1 & 0 & - \\
\hline 1912 & -26 & -72 & -3 & 42 & 26 & 3 & 175 & 0.24 \\
\hline 1913 & -59 & -59 & -59 & 59 & 59 & 1 & 0 & - \\
\hline 1914 & -75 & -303 & 91 & 183 & 136 & 3 & 152 & 1.2 \\
\hline 1915 & -44 & -181 & 44 & 81 & 59 & 6 & 709 & 0.11 \\
\hline 1916 & -145 & -205 & -88 & 152 & 145 & 5 & 445 & 0.34 \\
\hline 1917 & -72 & -85 & -51 & 74 & 72 & 3 & 59 & 1.25 \\
\hline 1918 & -19 & -31 & -7 & 23 & 19 & 2 & 89 & 0.25 \\
\hline 1921 & -72 & -72 & -72 & 72 & 72 & 1 & 0 & - \\
\hline 1922 & 76 & 76 & 76 & 76 & 76 & 1 & 0 & - \\
\hline 1923 & -49 & -95 & 24 & 71 & 65 & 3 & 321 & 0.22 \\
\hline 1924 & -28 & -72 & 16 & 46 & 39 & 3 & 211 & 0.22 \\
\hline 1925 & -9 & -69 & 40 & 46 & 37 & 3 & 488 & 0.09 \\
\hline 1926 & -71 & -174 & 52 & 98 & 83 & 11 & 915 & 0.11 \\
\hline 1927 & -82 & -133 & -32 & 97 & 82 & 2 & 164 & 0.59 \\
\hline 1928 & 20 & -11 & 69 & 40 & 27 & 3 & 860 & 0.05 \\
\hline 1929 & -41 & -132 & -16 & 58 & 41 & 6 & 745 & 0.08 \\
\hline 1930 & -21 & -231 & 58 & 100 & 66 & 6 & 447 & 0.22 \\
\hline 1931 & -21 & -102 & 86 & 67 & 52 & 9 & 908 & 0.07 \\
\hline 1932 & 4 & -39 & 101 & 43 & 33 & 8 & 829 & 0.05 \\
\hline 1933 & 3 & -97 & 137 & 53 & 40 & 19 & 886 & 0.06 \\
\hline 1934 & -35 & -183 & 117 & 71 & 48 & 34 & 931 & 0.08 \\
\hline 1935 & -18 & -110 & 83 & 49 & 40 & 35 & 946 & 0.05 \\
\hline 1936 & -6 & -223 & 110 & 53 & 41 & 167 & 1,024 & 0.05 \\
\hline 1937 & 6 & -99 & 217 & 59 & 43 & 71 & 1,214 & 0.05 \\
\hline 1938 & -12 & -230 & 217 & 87 & 65 & 89 & 1,235 & 0.07 \\
\hline 1939 & -8 & -207 & 192 & 69 & 50 & 92 & 1,021 & 0.07 \\
\hline 1940 & -8 & -251 & 179 & 68 & 51 & 112 & 889 & 0.08 \\
\hline 1941 & -5 & -237 & 203 & 75 & 54 & 101 & 1,024 & 0.07 \\
\hline 1942 & -30 & -327 & 130 & 87 & 62 & 121 & 1,197 & 0.07 \\
\hline 1943 & -37 & -273 & 142 & 85 & 66 & 41 & 822 & 0.1 \\
\hline 1944 & -30 & -309 & 126 & 98 & 78 & 27 & 846 & 0.12 \\
\hline 1945 & -19 & -303 & 99 & 79 & 52 & 26 & 989 & 0.08 \\
\hline
\end{tabular}


Table 1. Summary of hydraulic-head residual statistics for calibration of the Ozark groundwater-flow model, version 1.1.—Continued [RMSE, root mean square error; - , no value]

\begin{tabular}{|c|c|c|c|c|c|c|c|c|}
\hline Year & $\begin{array}{l}\text { Mean, } \\
\text { in feet }\end{array}$ & $\begin{array}{c}\text { Minimum } \\
\text { residual, } \\
\text { in feet }\end{array}$ & $\begin{array}{l}\text { Maximum } \\
\text { residual, } \\
\text { in feet }\end{array}$ & $\begin{array}{l}\text { RMSE, } \\
\text { in feet }\end{array}$ & $\begin{array}{c}\text { Mean } \\
\text { absolute error, } \\
\text { in feet }\end{array}$ & $\begin{array}{c}\text { Number of } \\
\text { observations }\end{array}$ & $\begin{array}{l}\text { Range, } \\
\text { in feet }\end{array}$ & $\begin{array}{c}\text { Ratio of } \\
\text { RMSE } \\
\text { to range }\end{array}$ \\
\hline 1946 & -10 & -269 & 186 & 77 & 56 & 75 & 1,053 & 0.07 \\
\hline 1947 & -22 & -260 & 149 & 72 & 52 & 75 & 1,030 & 0.07 \\
\hline 1948 & -40 & -270 & 92 & 86 & 62 & 66 & 956 & 0.09 \\
\hline 1949 & 12 & -215 & 663 & 141 & 68 & 46 & 1,948 & 0.07 \\
\hline 1950 & 82 & -204 & 555 & 248 & 156 & 58 & 1,478 & 0.17 \\
\hline 1951 & 60 & -223 & 557 & 203 & 109 & 64 & 1,327 & 0.15 \\
\hline 1952 & -60 & -279 & 170 & 101 & 75 & 46 & 1,071 & 0.09 \\
\hline 1953 & -17 & -272 & 769 & 170 & 95 & 60 & 1,596 & 0.11 \\
\hline 1954 & -59 & -297 & 232 & 97 & 73 & 112 & 1,222 & 0.08 \\
\hline 1955 & -39 & -341 & 208 & 93 & 66 & 166 & 1,195 & 0.08 \\
\hline 1956 & -53 & -313 & 126 & 102 & 69 & 141 & 1,159 & 0.09 \\
\hline 1957 & -65 & -300 & 198 & 116 & 81 & 163 & 1,065 & 0.11 \\
\hline 1958 & -42 & -465 & 213 & 96 & 70 & 122 & 1,166 & 0.08 \\
\hline 1959 & -32 & -266 & 318 & 86 & 62 & 135 & 1,096 & 0.08 \\
\hline 1960 & 1 & -307 & 284 & 81 & 58 & 316 & 1,193 & 0.07 \\
\hline 1961 & 2 & -356 & 459 & 98 & 68 & 270 & 1,509 & 0.06 \\
\hline 1962 & 35 & -227 & 466 & 122 & 74 & 381 & 1,342 & 0.09 \\
\hline 1963 & 3 & -270 & 473 & 95 & 61 & 261 & 1,365 & 0.07 \\
\hline 1964 & 11 & -238 & 271 & 76 & 57 & 451 & 1,236 & 0.06 \\
\hline 1965 & -4 & -224 & 357 & 74 & 54 & 400 & 1,633 & 0.05 \\
\hline 1966 & -17 & -251 & 162 & 68 & 51 & 252 & 1,149 & 0.06 \\
\hline 1967 & -17 & -198 & 215 & 70 & 56 & 244 & 1,164 & 0.06 \\
\hline 1968 & 28 & -631 & 771 & 127 & 77 & 213 & 1,717 & 0.07 \\
\hline 1969 & -37 & -500 & 189 & 119 & 73 & 130 & 1,157 & 0.1 \\
\hline 1970 & -19 & -227 & 140 & 67 & 53 & 151 & 1,119 & 0.06 \\
\hline 1971 & -27 & -343 & 132 & 81 & 61 & 118 & 1,046 & 0.08 \\
\hline 1972 & -24 & -288 & 162 & 77 & 56 & 128 & 1,039 & 0.07 \\
\hline 1973 & -29 & -312 & 163 & 76 & 57 & 230 & 1,103 & 0.07 \\
\hline 1974 & -48 & -320 & 201 & 101 & 71 & 203 & 1,037 & 0.1 \\
\hline 1975 & -24 & -293 & 373 & 79 & 48 & 197 & 1,528 & 0.05 \\
\hline 1976 & 1 & -244 & 142 & 45 & 28 & 184 & 1,100 & 0.04 \\
\hline 1977 & -21 & -204 & 333 & 63 & 42 & 221 & 1,178 & 0.05 \\
\hline 1978 & -37 & -314 & 108 & 67 & 47 & 285 & 1,119 & 0.06 \\
\hline 1979 & -39 & -348 & 144 & 72 & 51 & 165 & 1,034 & 0.07 \\
\hline 1980 & -32 & -313 & 517 & 88 & 57 & 165 & 1,441 & 0.06 \\
\hline
\end{tabular}


Table 1. Summary of hydraulic-head residual statistics for calibration of the Ozark groundwater-flow model, version 1.1.—Continued [RMSE, root mean square error; - , no value]

\begin{tabular}{|c|c|c|c|c|c|c|c|c|}
\hline Year & $\begin{array}{l}\text { Mean, } \\
\text { in feet }\end{array}$ & $\begin{array}{c}\text { Minimum } \\
\text { residual, } \\
\text { in feet }\end{array}$ & $\begin{array}{l}\text { Maximum } \\
\text { residual, } \\
\text { in feet }\end{array}$ & $\begin{array}{l}\text { RMSE, } \\
\text { in feet }\end{array}$ & $\begin{array}{c}\text { Mean } \\
\text { absolute error, } \\
\text { in feet }\end{array}$ & $\begin{array}{c}\text { Number of } \\
\text { observations }\end{array}$ & $\begin{array}{l}\text { Range, } \\
\text { in feet }\end{array}$ & $\begin{array}{c}\text { Ratio of } \\
\text { RMSE } \\
\text { to range }\end{array}$ \\
\hline 1981 & -53 & -312 & 91 & 72 & 60 & 482 & 995 & 0.07 \\
\hline 1982 & -56 & -305 & 71 & 72 & 61 & 526 & 1,039 & 0.07 \\
\hline 1983 & -33 & -202 & 194 & 70 & 56 & 146 & 827 & 0.09 \\
\hline 1984 & -54 & -209 & 95 & 74 & 62 & 146 & 921 & 0.08 \\
\hline 1985 & -57 & -210 & 64 & 76 & 63 & 166 & 995 & 0.08 \\
\hline 1986 & -64 & -229 & 99 & 87 & 71 & 173 & 980 & 0.09 \\
\hline 1987 & -47 & -317 & 605 & 97 & 72 & 276 & 1,845 & 0.05 \\
\hline 1988 & -34 & -181 & 641 & 98 & 67 & 156 & 1,690 & 0.06 \\
\hline 1989 & -29 & -309 & 408 & 84 & 60 & 248 & 1,570 & 0.05 \\
\hline 1990 & -17 & -235 & 706 & 85 & 58 & 303 & 1,853 & 0.05 \\
\hline 1991 & 2 & -207 & 706 & 87 & 59 & 303 & 1,720 & 0.05 \\
\hline 1992 & 10 & -217 & 408 & 87 & 65 & 411 & 1,503 & 0.06 \\
\hline 1993 & 18 & -246 & 403 & 88 & 65 & 371 & 1,550 & 0.06 \\
\hline 1994 & -1 & -173 & 190 & 64 & 47 & 77 & 1,006 & 0.06 \\
\hline 1995 & -12 & -358 & 272 & 57 & 41 & 652 & 1,057 & 0.05 \\
\hline 1996 & -7 & -233 & 189 & 74 & 54 & 125 & 1,133 & 0.07 \\
\hline 1997 & 15 & -126 & 120 & 52 & 37 & 58 & 1,057 & 0.05 \\
\hline 1998 & 7 & -258 & 217 & 65 & 46 & 346 & 1,049 & 0.06 \\
\hline 1999 & 7 & -194 & 169 & 60 & 47 & 189 & 665 & 0.09 \\
\hline 2000 & 4 & -265 & 248 & 83 & 60 & 658 & 926 & 0.09 \\
\hline 2001 & 11 & -786 & 285 & 67 & 43 & 628 & 1,795 & 0.04 \\
\hline 2002 & 3 & -276 & 155 & 55 & 38 & 738 & 1,169 & 0.05 \\
\hline 2003 & 8 & -264 & 215 & 56 & 40 & 765 & 1,130 & 0.05 \\
\hline 2004 & -17 & -793 & 280 & 78 & 46 & 352 & 1,616 & 0.05 \\
\hline 2005 & -13 & -257 & 90 & 59 & 41 & 298 & 1,041 & 0.06 \\
\hline 2006 & -18 & -453 & 287 & 81 & 55 & 623 & 1,074 & 0.08 \\
\hline 2007 & -20 & -633 & 211 & 71 & 49 & 452 & 1,547 & 0.05 \\
\hline 2008 & -33 & -275 & 93 & 70 & 52 & 302 & 1,105 & 0.06 \\
\hline 2009 & -23 & -221 & 92 & 63 & 47 & 440 & 1,089 & 0.06 \\
\hline 2010 & -30 & -655 & 204 & 74 & 52 & 507 & 1,562 & 0.05 \\
\hline 2011 & -29 & -263 & 106 & 70 & 53 & 396 & 1,111 & 0.06 \\
\hline 2012 & -34 & -233 & 119 & 74 & 56 & 349 & 1,109 & 0.07 \\
\hline 2013 & -21 & -242 & 85 & 70 & 54 & 64 & 846 & 0.08 \\
\hline all & -15 & -793 & 771 & 80 & 55 & 19,044 & 2,578 & 0.03 \\
\hline
\end{tabular}


The modifications made in model v1.1 generally improved the model fit to observed values. For example, the RMSE among all (19,044 comparisons) simulated and observed hydraulic heads is 80 in model v1.1 compared to 113 in model v1.0 (Clark and others, 2018). Additionally, the comparison of simulated stream leakage to estimated leakage improved from a coefficient of determination $\left(R^{2}\right)$ of 0.59 to 0.81 . Additional information regarding updated parameter values and the fit of the model to observed data is contained in appendix 1 .

\section{Conceptualization of the Hydrologic System}

The Ozark system is conceptualized as a hydrologic budget, with inflows from precipitation and losing-stream reaches and lateral inflow from neighboring surface-water and groundwater systems (Hays and others, 2016). Outflows are to gaining-stream reaches and springs, lateral groundwater flow to neighboring systems, and withdrawals for water use (Hays and others, 2016). The Ozark system is assumed to be at or near hydrologic equilibrium, so net gains and losses of water, and thus the hydrologic budget, are balanced. When there is a surplus of recharge, the additional water can flow into storage, numerically representing a loss of groundwater from the aquifer system, which is represented by negative values in the hydrologic budget. Likewise, when there is a deficit of recharge, water released from storage provides a source of water to the aquifer system, which is represented by positive values in the hydrologic budget. Thus, groundwater storage can serve as both an inflow and outflow to the groundwater system. As water in storage is depleted, the water level will decline until an additional inflow is introduced or until the area dries up. Evaluation of areas where the inflows and outflows do not balance can indicate where stresses exist or are developing. Additionally, there may be both inflow and outflow in localized parts of the system for a single component of the hydrologic budget, but budget components for the entire aquifer system are conceptualized as net fluxes, where the overall flux will have a net positive (inflow) or negative (outflow) value. Predevelopment conditions include the period prior to 1900 when steady-state conditions were achieved through outflows to streams, springs, and neighboring systems; after 1900, outflows additionally included groundwater withdrawals (Knierim and others, 2017) under transient conditions and associated changes in aquifer storage (fig. 6).

Recharge from precipitation is the largest source of freshwater to the Ozark system. Average annual precipitation varies from 28 to 63 inches per year (in/yr) in the study area, with an average of $44 \mathrm{in} / \mathrm{yr}$ (Hays and others, 2016). Most rainfall occurs during April, May, and June, and precipitation increases generally from north to south across the study area (Hays and others, 2016). Approximately 34,560 Mgal/d of water, or 24 percent of precipitation in the area, recharges the Ozark system according to an SWB model developed for the Ozark system for the period 2005 to 2014 (Hays and others, 2016). Based on land-surface area for aquifers of the Ozark system, 66 percent $(22,800 \mathrm{Mgal} / \mathrm{d})$ of the total recharge contributes to the Springfield Plateau and upper, middle, and lower Ozark aquifers (fig. 6A) (Hays and others, 2016). Recharge was found to be variable across the Ozark Plateaus, depending on variables in the SWB model, including precipitation, temperature, vegetation, and soil properties (Westenbroek and others, 2010).

Because of the dome-like structure of the Ozark system, lateral groundwater and surface-water inflow are hypothesized to be small and there is a net volume of groundwater outflow at the boundaries of the Ozark system (fig. 6). In the western part of the study area, groundwater mixing occurs at the freshwater-saltwater transition zone (fig. 1), such that saline groundwater from the Western Interior Plains aquifer system contributes water to surface water and groundwater at the margins of the Ozark system (Hays and others, 2016). At the scale of a regional groundwater-flow model, this contribution is negligible and therefore not included as a net inflow for the conceptual Ozark system hydrologic budget. Although groundwater pumping could induce flow from the saline groundwater system in areas along the freshwater/saltwater transition zone (Czarnecki and others, 2009; Macfarlane and others, 2005), quantifying localized groundwater flow between the Ozark system and Western Interior Plains aquifer system is more suited to studies done at finer scales than represented in this regional model.

Groundwater outflow occurs along the western and eastern margins of the study area. Approximately 2,000 Mgal/d (or about 9 percent of recharge) of groundwater flows to neighboring groundwater systems and streams (Hays and others, 2016; Imes and Emmett, 1994; Mesko and Imes, 1995). Based on previous modeling efforts (Mesko and Imes, 1995), most of the groundwater outflow occurs along the eastern margins of the study area where Paleozoic-age units of the Ozark system are in hydraulic connection with Tertiary-age units of the Mississippi embayment system (figs. $6 A$ and $B$ ).

Groundwater-surface-water interaction is common in the Ozark system, with highly transmissive fractured karst conduits providing strong connections between groundwater and surface water. Streams alternate between gaining (receiving water from the groundwater system) and losing (losing water to the groundwater system) over relatively short distances as a function of time depending on precipitationdriven groundwater flow and river stage (Hays and others, 2016; Knierim and others, 2015). Springs also contribute to surface-water flow throughout the Ozarks. Analysis of the seepage-run dataset spanning 24 years (Knierim and others, 2015) indicated that, in total, interior Ozark system streams (that is, streams that are not at major boundaries of the Ozark system) are gaining and, gaining flows combined with springflow, receive approximately $20,700 \mathrm{Mgal} / \mathrm{d}$ from groundwater (figs. 6A and B) (Hays and others, 2016). 
$\boldsymbol{A}$

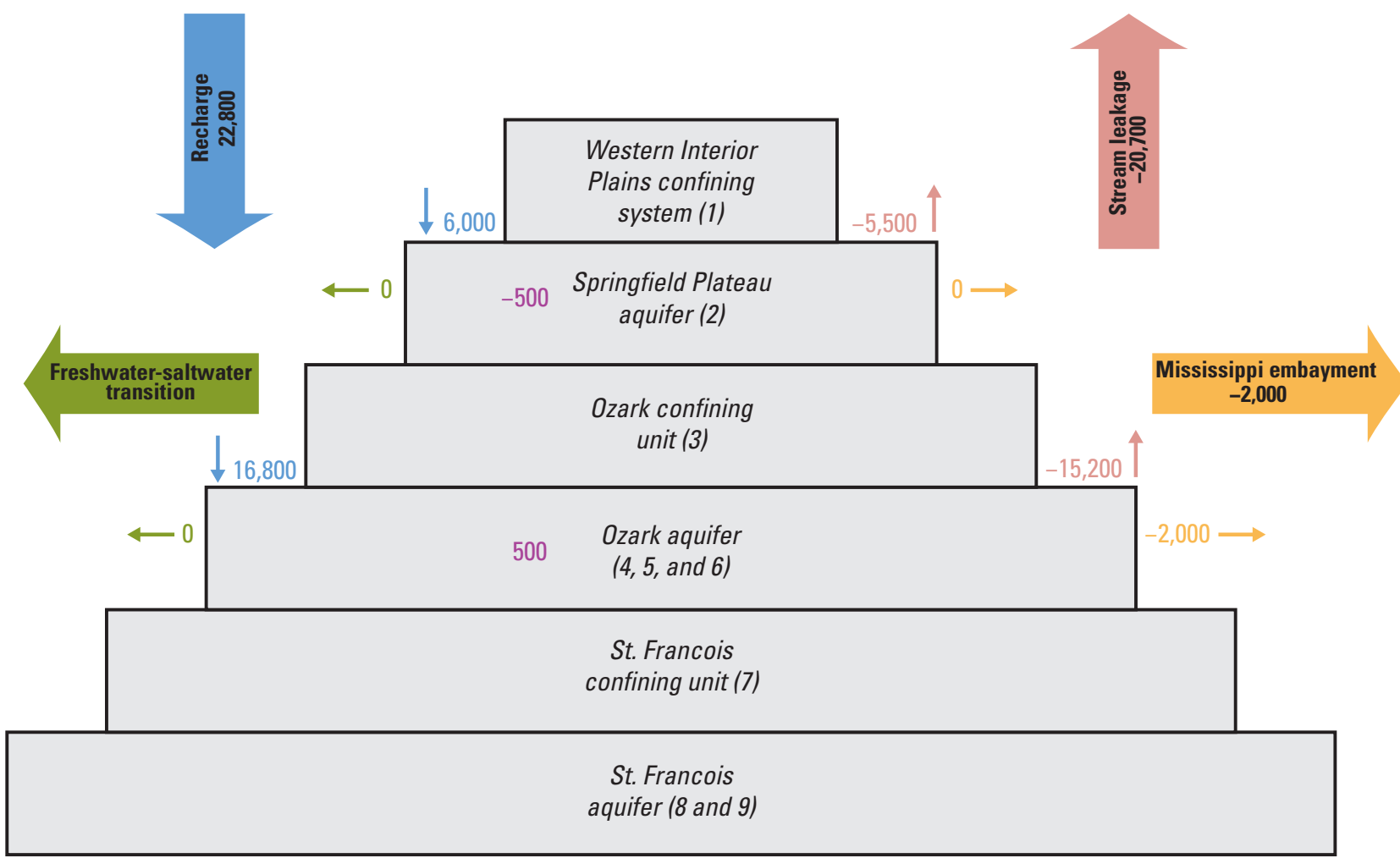

VALUES MAY NOT SUM TO REPORTED TOTALS DUE TO ROUNDING

\section{EXPLANATION}

All units are in million gallons per day

Recharge

Stream leakage

Freshwater-saltwater transition

Mississippi embayment

-500 Internal flow

(1) Model layer, see fig. 2

Figure 6. Hydrologic budget for conceptual model of Hays and others (2016) for $A$, predevelopment and $B$, postdevelopment conditions and numerical analysis in this report of $C$, predevelopment (before 1900) and $D$, average postdevelopment (April 1, 1996-0ctober 1, 2015) conditions. Negative values indicate water discharged from the hydrogeologic unit; positive values represent water recharged to the hydrogeologic unit. 


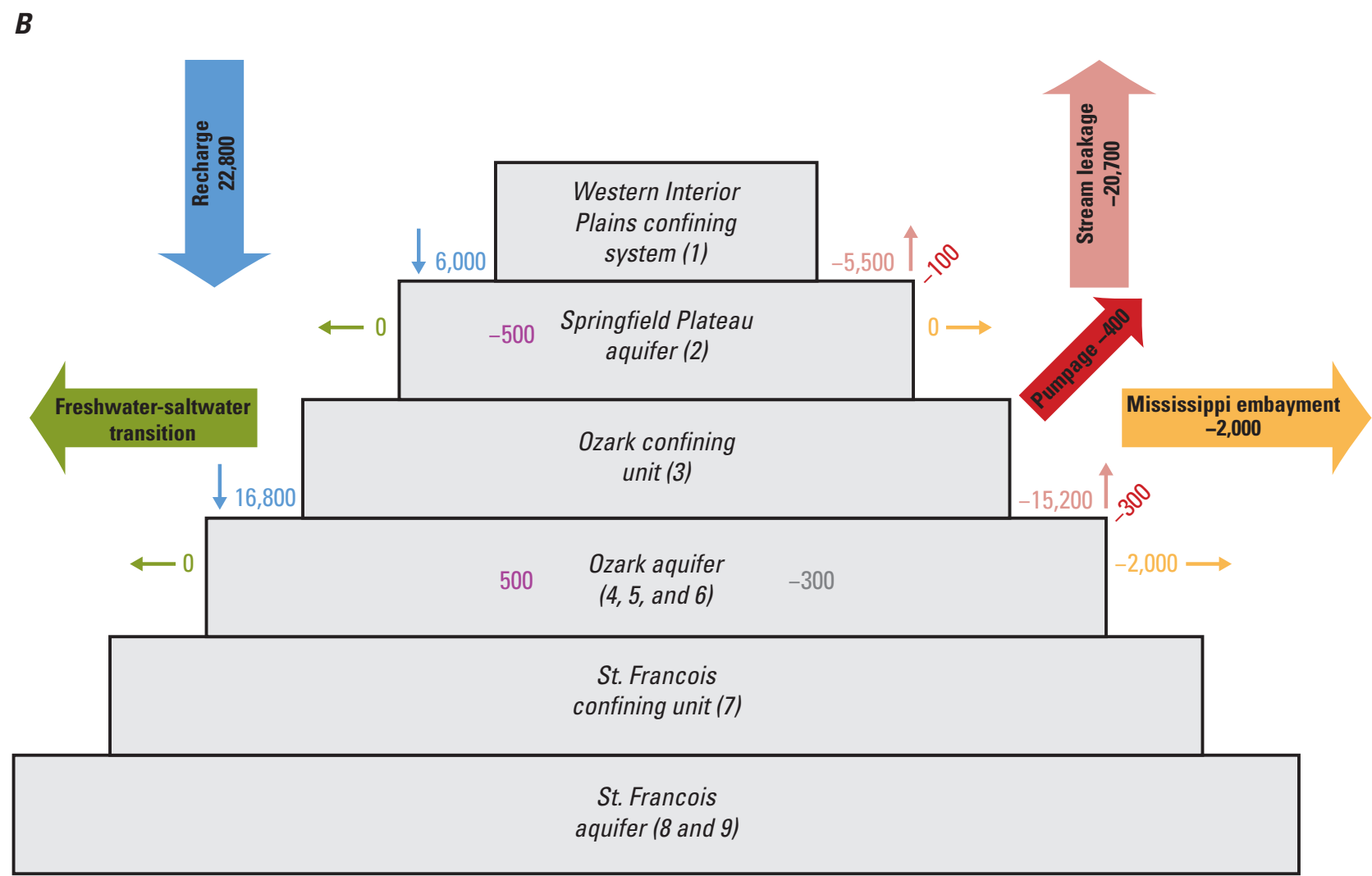

VALUES MAY NOT SUM TO REPORTED TOTALS DUE TO ROUNDING

\section{EXPLANATION}

All units are in million gallons per day

\begin{tabular}{|l|l}
\hline Recharge \\
\hline Stream leakage \\
\hline Freshwater-saltwater transition \\
\hline & Mississippi embayment \\
\hline & Pumpage \\
\hline-500 & Internal flow \\
\hline-300 & Internal storage \\
\hline (1) Model layer, see fig. 2
\end{tabular}

Figure 6. Hydrologic budget for conceptual model of Hays and others (2016) for $A$, predevelopment and $B$, postdevelopment conditions and numerical analysis in this report of $C$, predevelopment (before 1900) and $D$, average postdevelopment (April 1, 1996-0ctober 1, 2015) conditions. Negative values indicate water discharged from the hydrogeologic unit; positive values represent water recharged to the hydrogeologic unit.-Continued 


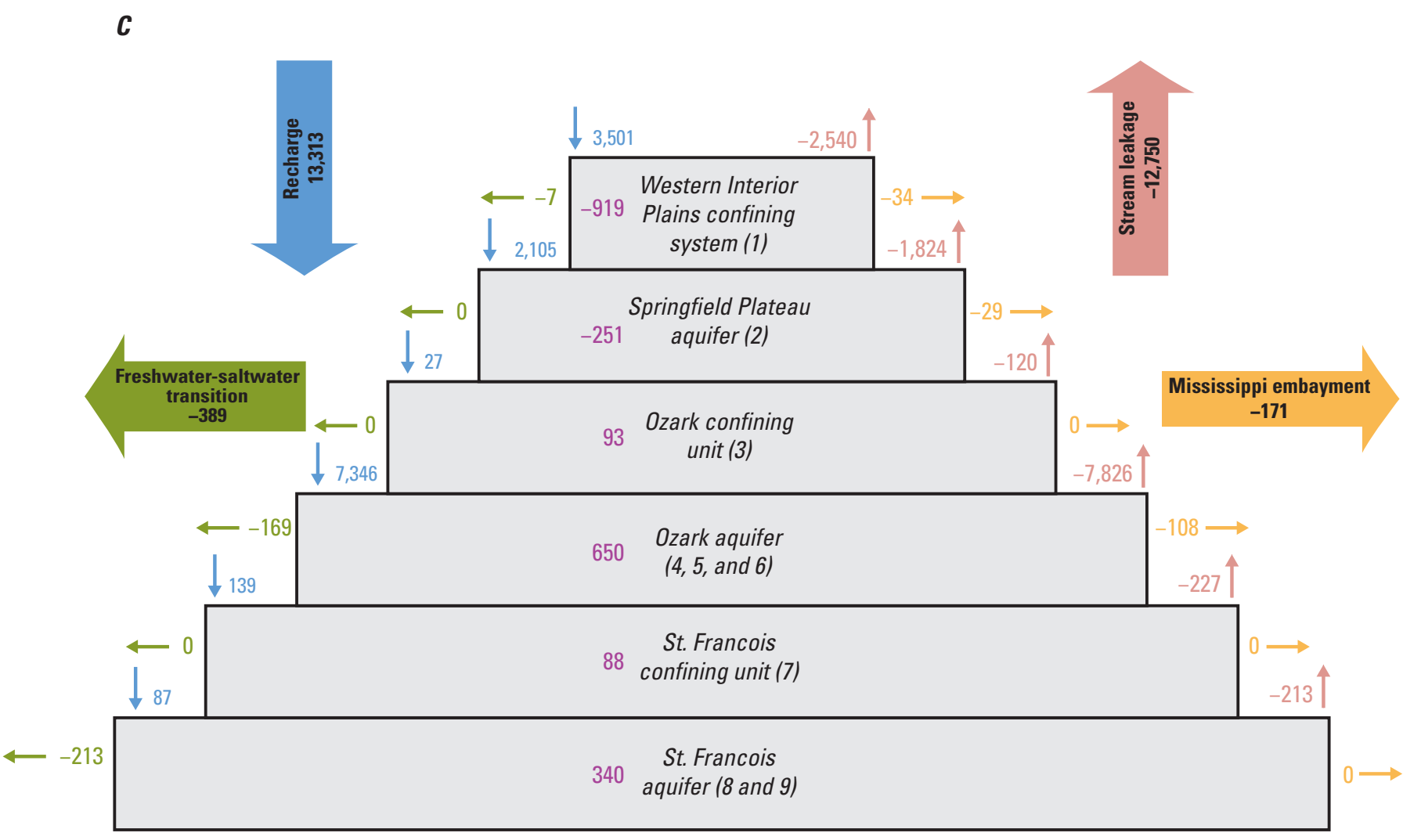

VALUES MAY NOT SUM TO REPORTED TOTALS DUE TO ROUNDING

\section{EXPLANATION}

All units are in million gallons per day

\begin{tabular}{|l}
\hline Recharge \\
Stream leakage \\
Freshwater-saltwater transition \\
Mississippi embayment \\
\hline-919 Internal flow \\
\hline (1) Model layer, see fig. 2
\end{tabular}

Figure 6. Hydrologic budget for conceptual model of Hays and others (2016) for $A$, predevelopment and $B$, postdevelopment conditions and numerical analysis in this report of $C$, predevelopment (before 1900) and $D$, average postdevelopment (April 1, 1996-0ctober 1, 2015) conditions. Negative values indicate water discharged from the hydrogeologic unit; positive values represent water recharged to the hydrogeologic unit.-Continued 


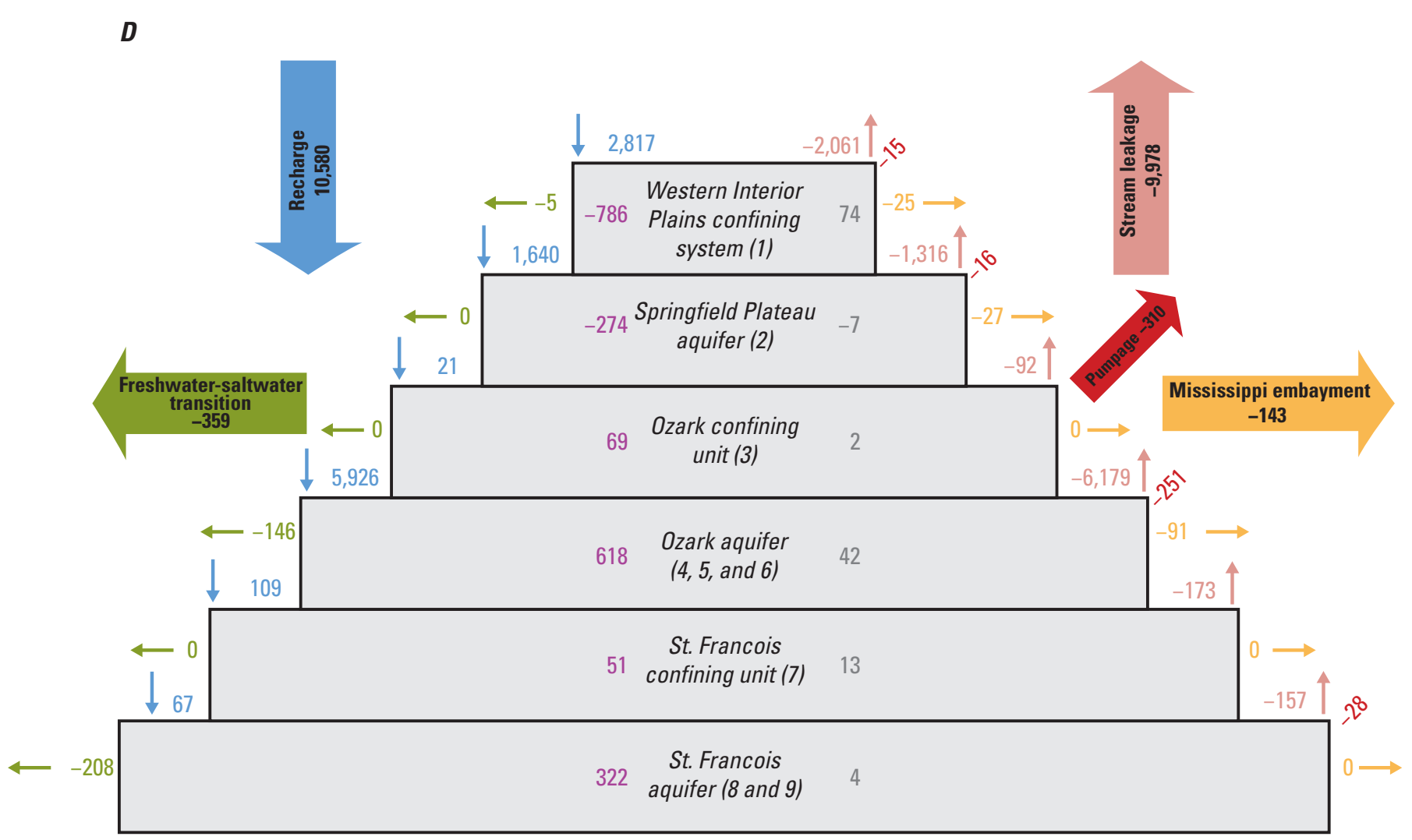

VALUES MAY NOT SUM TO REPORTED TOTALS DUE TO ROUNDING

\section{EXPLANATION}

All units are in million gallons per day

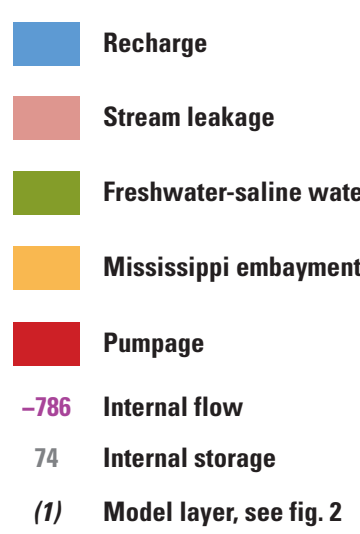

Figure 6. Hydrologic budget for conceptual model of Hays and others (2016) for $A$, predevelopment and $B$, postdevelopment conditions and numerical analysis in this report of $C$, predevelopment (before 1900) and $D$, average postdevelopment (April 1, 1996-0ctober 1, 2015) conditions. Negative values indicate water discharged from the hydrogeologic unit; positive values represent water recharged to the hydrogeologic unit.-Continued 
Therefore, about 91 percent of recharge to the Ozark system is returned to the surface through springs or streambed discharge. Groundwater maintenance of streams is important for ecosystems in the Ozark system because groundwater supports a variety of habitats and species and provides a time-averaged input of water to streams (Hays and others, 2016).

The $400 \mathrm{Mgal} / \mathrm{d}$ of groundwater withdrawn from the Ozark system in 2010 (fig. 6B) was approximately 2 percent of the total recharge rate. Because of low storage in aquifers, cones of depression with steep water-level gradients can develop quickly around pumping centers (Hays and others, 2016; Richards, 2010). Therefore, even though a pumping rate is small from a regional perspective, aquifer characteristics are such that high rates of local pumping have the potential to locally create shortages of water during even short periods of drought. Potentiometric maps of groundwater levels in the Ozark system with increased density of measured wells around urban pumping zones indicates localized cones of depression (Richards and Mugel, 2008) compared to regional potentiometric maps that are used to characterize the regional groundwater-flow system (Nottmeier, 2015). Therefore, site-specific water use on a scale finer than the Ozark system model grid may be important for accurately characterizing groundwater availability in urban areas.

\section{Simulation of the Hydrologic System}

Model v1.1 was used to assess changes in simulated hydrologic budget components from January 1, 1900, to April 1, 2016, at the regional scale to quantify hydrologic changes across the Ozark system. Model v1.1 was also used to simulate the potential future conditions for 2016-2060 under the baseline, pumping, and general circulation model (GCM) scenarios. While scenario conditions are simulated in an approximate manner, the groundwater-flow model results can be used to gain insights into the range of possible futures, allowing planning by resource managers and identification of future research needs.

\section{Comparison of the Conceptualized and Simulated Hydrologic Systems}

Comparing the conceptual hydrologic budget (Hays and others, 2016) with the numerical groundwater-flow model v1.1 budget provides a way to evaluate current understanding of the aquifer system in the context of a numerical solution to groundwater flow. Conceptual hydrologic budget components were estimated by Hays and others (2016) using previous groundwater modeling efforts, field research into groundwater - surface-water interaction, a water-use model based on reported groundwater withdrawals, and the component of precipitation gained as recharge from a SWB model. The numerical groundwater-flow model refines these estimates and improves the understanding of regional groundwater flow and water availability in the Ozark system. Groundwater fluxes simulated in model v1.1 include predevelopment and average postdevelopment conditions for comparison to the conceptual model budget. The postdevelopment period discussed throughout the report spans from April 1, 1996, to April 1, 2016, and is emphasized for several reasons: (1) groundwater pumping steadily increased until 2010 (Clark and others, 2018; Knierim and others, 2016, 2017); (2) estimated net pumpage stabilized around means of $422 \mathrm{Mgal} / \mathrm{d}$ and $119 \mathrm{Mgal} / \mathrm{d}$ for summer and winter stress periods, respectively, during this postdevelopment timeframe; and (3), there was no appreciable trend in simulated net areal recharge during this period.

\section{Comparison of Predevelopment Conditions Between the Conceptualized and Simulated Hydrologic Systems}

Recharge calculated for the conceptual model hydrologic budget (using SWB) was $34,560 \mathrm{Mgal} / \mathrm{d}$ for the entire Ozark system, of which $6,000 \mathrm{Mgal} / \mathrm{d}$ recharged the Springfield Plateau aquifer and $16,800 \mathrm{Mgal} / \mathrm{d}$ recharged the upper, middle, and lower Ozark aquifers (Hays and others, 2016). Although the SWB model provides a thermodynamic budget approach to calculate recharge across an entire study area, SWB results for recharge were generally high compared to other estimates compiled for the conceptual model of the Ozark system (Hays and others, 2016). To provide a more conservative estimate of recharge for initial values in the groundwater-flow model, values calculated through annual regression-based methods (referred to as the Empirical Water Balance; EWB [Reitz and others, 2015, 2017]) were substituted for SWB values during model calibration (see Clark and others [2018] for methods). Recharge from EWB grids (averaged from 2000 to 2013) was 12,994 Mgal/d for the entire system, of which 3,324 Mgal/d and 9,670 Mgal/d recharged the Springfield Plateau aquifer and upper, middle, and lower Ozark aquifers, respectively (Reitz and others, 2017). Recharge simulated in model v1.1 was lower than recharge estimated by SWB or EWB: 2,105 Mgal/d for the Springfield Plateau aquifer and 7,346 Mgal/d for the upper, middle, and lower Ozark aquifers (plus approximately $108 \mathrm{Mgal} / \mathrm{d}$ from precipitation that falls on the outcrop area of stratigraphically equivalent rocks in north-central Missouri [fig. 1] is included with recharge in fig. 6C).

Although not representing the same periods, recharge from the groundwater-flow model version 1.1 and EWB were more similar than the recharge values estimated by SWB methods even after adjustment through parameter estimation, such that EWB provides reliable, continuous estimates of recharge. Previous groundwater-flow models of the Ozark system also estimated lower recharge values compared to SWB methods that use principles similar to SWB (Imes and Emmett, 1994). Recharge calculated from SWB may be better thought of as soil drainage - or water that drains from the soil 
zone - and incorporating surface geologic information into recharge calculations may provide context for the amount of soil drainage that realistically contributes recharge to underlying groundwater systems. For example, in the EWB approach, surficial geology was found to improve estimates of hydrologic budget components, including quick-flow runoff, evapotranspiration, and recharge (Reitz and others, 2017).

Therefore, soil-focused approaches to estimating recharge may generally overestimate recharge compared to methods that calibrate to a balanced water budget, such as EWB methods or numerical groundwater-flow models.

In the conceptual hydrologic budget, the groundwater transferred among aquifers of the Ozark system was primarily estimated as $500 \mathrm{Mgal} / \mathrm{d}$ of vertical flow from the Springfield Plateau aquifer into units of the Ozark aquifer (Hays and others, 2016) (figs. $6 A$ and $B$ ). One of the benefits of using a groundwater-flow model is that estimates of groundwater flux among hydrogeologic units within a groundwater system can be more easily quantified than if no model is used. Based on model v1.1, the Springfield Plateau aquifer loses approximately $251 \mathrm{Mgal} / \mathrm{d}$, the Ozark aquifer receives $650 \mathrm{Mgal} / \mathrm{d}$, and the St. Francois aquifer receives $340 \mathrm{Mgal} / \mathrm{d}$ from other units within the Ozark system for predevelopment conditions (fig. 6C). Groundwater fluxes among aquifers calculated with model v1.1 are different from previous regional groundwater-flow model results; Imes and Emmett (1994) calculated that $757 \mathrm{Mgal} / \mathrm{d}$ was lost from the Springfield Plateau aquifer and $190 \mathrm{Mgal} / \mathrm{d}$ was lost from the Ozark aquifer. Additionally, much more groundwater flows into the St. Francois aquifer (340 Mgal/d) in model v1.1 (fig. 6C) compared to $24 \mathrm{Mgal} / \mathrm{d}$ as reported by Imes and Emmett (1994), possibly owing to more accurate representation of the aquifers through refined discretization (model v1.1 uses two layers to represent the St. Francois aquifer).

Interaction among the Ozark system and neighboring surface-water and groundwater systems was conceptualized as a net outflow, with inflows being minimal because of the geometry of the Ozark system (fig. 3B) (Hays and others, 2016). Lateral groundwater outflow was estimated to be 2,000 Mgal/d for the conceptual hydrologic budget (Imes and Emmett, 1994; Mesko and Imes, 1995), compared to approximately $560 \mathrm{Mgal} / \mathrm{d}$ (fig. 6C; table 2) of groundwater exiting the Ozark system through the freshwater-saltwater transition zone and to the east to the Mississippi embayment in model v1.1.

In model v1.1, most (389 Mgal/d) of the simulated $560 \mathrm{Mgal} / \mathrm{d}$ exiting the system as lateral groundwater flow leaves the Ozark system along the northwestern margin of the study area near the freshwater-saltwater transition zone (fig. 1). Of the $389 \mathrm{Mgal} / \mathrm{d}$ of groundwater that flows to constant head boundaries at the freshwater-saltwater transition zone, approximately 55 percent $(213 \mathrm{Mgal} / \mathrm{d})$ flows from the St. Francois aquifer and 44 percent (169 Mgal/d) flows from the Ozark aquifer. Based on an end-member mixing model using chloride data for the conceptual hydrologic budget (Hays and others 2016), up to 20 percent of groundwater in the freshwater-saltwater transition zone was contributed from the neighboring Western Interior Plains aquifer system (Hays and others, 2016). Based on simulated groundwater flow in model v1.1, mixing of groundwater in the freshwater-saltwater transition zone does not represent a net influx of water into the Ozark system because $389 \mathrm{Mgal} / \mathrm{d}$ of groundwater leaves the Ozark system through the constant-head boundary (fig. 6C).

Table 2. Hydrologic budget for the numerical groundwater-flow model for the predevelopment period (before 1900) and minimum, average, standard deviation, and maximum values for the postdevelopment period (April 1, 1996, to April 1, 2016).

[Values are in million gallons per day with positive values signifying net inflows to the groundwater system and negative values signifying net outflows]

\begin{tabular}{|c|c|c|c|c|c|}
\hline \multirow{3}{*}{ Hydrologic budget component } & \multicolumn{5}{|c|}{ Time period } \\
\hline & \multirow[b]{2}{*}{ Predevelopment } & \multicolumn{4}{|c|}{ Postdevelopment } \\
\hline & & Minimum & Average & $\begin{array}{l}\text { Standard } \\
\text { deviation }\end{array}$ & Maximum \\
\hline Recharge & 13,205 & 1,387 & 10,580 & 6,465 & 23,467 \\
\hline \multicolumn{6}{|l|}{ Lateral groundwater outflow } \\
\hline Freshwater-saltwater transition zone & -389 & -377 & -359 & 9 & -346 \\
\hline Embayment & -171 & -239 & -143 & 46 & -73 \\
\hline Discharge to streams & $-12,750$ & $-14,720$ & $-9,978$ & 2,013 & $-6,588$ \\
\hline Groundwater pumping & 0 & -934 & -310 & 219 & -65 \\
\hline Aquifer storage & 0 & & 128 & 4,791 & \\
\hline Storage release & & 0 & & & 7,228 \\
\hline Storage replenishment & & $-8,222$ & & & 0 \\
\hline
\end{tabular}


The remainder of net groundwater outflow (171 Mgal/d) occurs through the unconsolidated units of the Mississippi embayment on the eastern margin of the study area (fig. $3 B$ ), including the McNairy-Nacatoch aquifer of Cretaceous-age and Tertiary-age units. Approximately 20 percent (34 Mgal/d) of the remaining $171 \mathrm{Mgal} / \mathrm{d}$ discharges from the Western Interior Plains confining system near the fall line (fig. 1), and 63 percent (108 Mgal/d) discharges from the Ozark aquifer (fig. 6C). However, discharge from the individual hydrogeologic units of the Ozark system to the Mississippi embayment is best considered as the summed value $(171 \mathrm{Mgal} / \mathrm{d})$ because of limitations in the hydrogeologic framework at system boundaries. Groundwater outflow to the Mississippi embayment may be overestimated because of the simulated direct connection between Ozark system aquifers and the Mississippi embayment in model v1.1. The direct hydraulic connection is an artifact of model construction; parts of the Western Interior Plains confining system, Springfield Plateau, Ozark confining unit, and Ozark aquifer layers are replaced by properties representing the Mississippi embayment in the southeastern model area. Groundwater flow into the general-head boundary through the Mississippi embayment could also represent discharge into streams, as was shown through seepage studies of streams along the fall line (Mesko and Imes, 1995). The interaction of groundwater between Paleozoic-age units of the Ozark system and Cretaceous-age and younger units of the Mississippi embayment remains an important question because of the high amount of groundwater use from alluvial aquifers and limitations in groundwater-flow models at model boundaries.

Groundwater discharge to streams and springs was conceptualized as a major loss of water from the Ozark system, accounting for approximately 91 percent of recharge (Hays and others, 2016). Based on seepage-run studies, largemagnitude spring discharges, and balance among hydrologic budget components, approximately $20,700 \mathrm{Mgal} / \mathrm{d}$ of water moved from Ozark system aquifers to streams (figs. $6 \mathrm{~A}$ and $B$ ) according to the conceptual model of Hays and others (2016). Based on the model v1.1, 12,750 Mgal/d discharged to streams across the Ozark system (excluding the Mississippi embayment area), accounting for 95 percent of simulated recharge $(13,205 \mathrm{Mgal} / \mathrm{d})$ during the predevelopment period (fig. 6C). Streams overlying the outcrop area of the Springfield Plateau aquifer (fig. 1) received 1,824 Mgal/d from groundwater or approximately 87 percent of recharge to the aquifer (fig. $6 \mathrm{C}$ ). The Ozark aquifer discharged more groundwater to streams $(7,826 \mathrm{Mgal} / \mathrm{d})$ than was received by recharge over the outcrop area of the Ozark aquifer $(7,346 \mathrm{Mgal} / \mathrm{d})$ because the Ozark aquifer received an additional source of water $(650 \mathrm{Mgal} / \mathrm{d})$ from other model layers. The high degree of groundwater - surface-water interaction typical of karst hydrogeology is reflected in the calibrated hydrologic budget of the Ozark system by the large portion of recharge that enters the groundwater system and then discharges back to surface water (figs. $6 C$ and $D$ ). However, streams were modeled as net sinks in the groundwater-flow model, such that finer-scale groundwatersurface-water interaction was not explicitly modeled. For example, single stream reaches changing between gaining and losing, as have been observed in field-scale studies (Knierim and others, 2015), were not represented at scales smaller than several miles. Future modeling efforts may benefit from a better understanding of the surface-water connection with the groundwater system, especially because groundwater outflow to streams and springs is such a large portion of the hydrologic budget and groundwater is an important source of recharge for streams.

\section{Comparison of Postdevelopment Conditions Between the Conceptualized and Simulated Systems}

Generally, model v1.1 hydrologic-budget components for average postdevelopment (1996-2016) recharge, lateral groundwater outflow (including outflow to constant-head and general-head boundaries), and discharge to streams were similar to the predevelopment values (table 2), such that comparisons to the conceptual hydrologic budget are similar. Over the postdevelopment period in model v1.1, recharge ranged from 1,387 to $23,467 \mathrm{Mgal} / \mathrm{d}$, reflecting seasonal variability represented by 6 -month time steps as the model calibrated to groundwater-level altitudes. The largest groundwater outflow was discharge to streams, which ranged from 6,588 to $14,720 \mathrm{Mgal} / \mathrm{d}$.

Water use for the conceptual model budget was computed by using USGS and State estimates of groundwater-withdrawal rates and was $380 \mathrm{Mgal} / \mathrm{d}$ in 2010 (Knierim and others, 2016, 2017), which corresponds to approximate (rounded) values of 100 and $300 \mathrm{Mgal} / \mathrm{d}$ for the Springfield Plateau and Ozark aquifers, respectively (fig. $6 B$ ). Groundwater-withdrawal rates from the Ozark model v1.1 for the average postdevelopment period averaged $310 \mathrm{Mgal} / \mathrm{d}$ for all layers (fig. $6 D$; table 2) and ranged from $65 \mathrm{Mgal} / \mathrm{d}$ during the fall and winter (October through March) to $934 \mathrm{Mgal} / \mathrm{d}$ during the spring and summer (April through September). Groundwater withdrawals in 2010, according to model v1.1, were $472 \mathrm{Mgal} / \mathrm{d}$ from the Ozark system during the active pumping season of spring and summer, with $23 \mathrm{Mgal} / \mathrm{d}$ withdrawn from the Springfield Plateaus aquifer and $384 \mathrm{Mgal} / \mathrm{d}$ withdrawn from the Ozark aquifer. The model v1.1 groundwater withdrawals were $94 \mathrm{Mgal} / \mathrm{d}$ across the Ozark system in the winter of 2010, with $4 \mathrm{Mgal} / \mathrm{d}$ withdrawn from the Springfield Plateaus aquifer and $77 \mathrm{Mgal} / \mathrm{d}$ withdrawn from the Ozark aquifer. Groundwaterwithdrawal values from 2010 are reported for direct comparison to the conceptual hydrologic budget in Hays and others (2016) and modeled water use from Knierim and others (2016, 2017). Model v1.1 results indicate lower groundwater use on average compared to groundwater use in the conceptual budget (fig. 6); for example, $283 \mathrm{Mgal} / \mathrm{d}$ was the annual average in 2010 compared to $380 \mathrm{Mgal} / \mathrm{d}$ in the conceptual hydrologic budget (Knierim and others, 2016, 2017). 
The majority of groundwater withdrawals were from the lower Ozark aquifer, which in the summer of 2010 accounted for 62.4 percent of total withdrawals (fig. $7 A$ ). This ratio was relatively uniform across the study area except for Arkansas, where only 33.6 percent of groundwater withdrawals were from the lower Ozark aquifer (fig. 7B). In Arkansas, the middle Ozark aquifer supplied 16.7 percent of the demand, and the remaining 49.7 percent was distributed among the upper Ozark aquifer, the Springfield and St. Francois aquifers, and the local sands and fractures within the Western Interior Plains confining system. Oklahoma differs slightly from the other areas in that 22.8 percent of groundwater withdrawals are from the Springfield Plateaus aquifer (fig. $7 D$ ), which is likely because the Springfield Plateaus aquifer is sufficiently productive and present at land surface in much of the Oklahoma area simulated by model v1.1.

As inflows and outflows changed throughout the postdevelopment period under transient conditions, groundwater was released from storage (inflow) as water levels declined or groundwater storage was replenished (outflow) as water levels rose. Aquifer storage represents the quantity of water in an aquifer, and available storage volume may act as a source or sink for groundwater as stresses on an aquifer system change (Hays and others, 2016). In the conceptual hydrologic budget, changes in storage were assumed to balance groundwater use, which was the only flux that differed between predevelopment and postdevelopment periods (figs. $6 A$ and $B$ ). Storage fluxes were much greater in model v1.1 than can be attributed to only changes in groundwater withdrawals: storage ranged from $7,228 \mathrm{Mgal} / \mathrm{d}$ flowing into the system (release from storage) to $8,222 \mathrm{Mgal} / \mathrm{d}$ removed from the system (replenishment to storage) suggesting that changes in recharge may have a much greater influence on storage change than groundwater withdrawals (table 2).

\section{Hydrologic Budget—Groundwater Availability}

As discussed previously, the hydrologic budget for the Ozark system is balanced between net inflows and outflows of groundwater. During predevelopment, steady-state conditions, this balance is achieved through inflows from recharge and outflows to streams, springs, and neighboring systems. After 1900, outflows additionally included groundwater withdrawals (Knierim and others, 2017) under transient conditions and associated changes in aquifer storage (figs. $6 B$ and $D$ ).

\section{Changes in the Hydrologic Budgets Over Time}

The simulation of groundwater flow using model v1.1 provides a regional hydrologic budget from 1900 to 2016 (fig. 8). The inflows and outflows throughout the early period of the simulation, from 1900 to about 1965 are relatively uniform, with inflow from recharge of about 13,000 Mgal/day. Much of this inflow of water is discharged through streams in the system to balance the hydrologic budget (fig. 8A). Changes in storage over time (from outflows to inflows) reflect the large variability in recharge. If recharge decreases, water levels will decrease, discharge to streams will also decrease, and groundwater may be released from aquifer storage to provide an inflow to the aquifer system. Conversely, when recharge increases, water levels will increase, discharge to streams will also increase, and storage can be replenished (numerically representing a loss of groundwater from the aquifer system). The uniformity of flows during the early period (1900-1965) is partially a product of the model development. Because less information about pumping and water-level observations is available for the early period than for 1966-2016, only two stress periods are used to define the time from 1900 to 1965; these stress periods each use average values of recharge and pumping. The net change in groundwater storage throughout this early period is essentially zero. After 1965, variability in recharge increases as the temporal resolution of the simulation increases, with stress periods representing 12to 6-month periods rather than multiple years. The period after 1965 also corresponds to an approximate doubling of withdrawals until the late 1990s (fig. 8B). After the 1990s, average withdrawals approximately double again through the end of the history matching period (2016). With these increases in withdrawals, there is a corresponding decrease, though smaller in magnitude, in discharge through the constant head boundary, which represents flow through the freshwater-saltwater transition zone along the western edge of the model boundary. This decrease in flow may essentially account for captured water that is withdrawn from wells rather than discharging further west. Conversely, a similar decrease in discharge to streams after 1965 appears to correspond to fluctuations in recharge. The decrease in flow to the constant heads could also be related to the fluctuations in recharge or to a combination of changes in recharge and withdrawals.

Most of the groundwater withdrawals from the Ozark system occur in Missouri, with more than a third of withdrawals from southwest Missouri (fig. 9). Kansas uses the most groundwater from the lower Ozark aquifer, with lesser amounts from the Western Interior Plains confining system where use has declined over the last three decades. Oklahoma's second largest source of groundwater is from the Springfield Plateau aquifer, with slight increases in the 1990s followed by relatively level average withdrawals. Midway through the simulation period (1940 to the late 1990s), some of the largest withdrawals in Arkansas are from the uppermost model layer representing the Western Interior Plains confining system. 


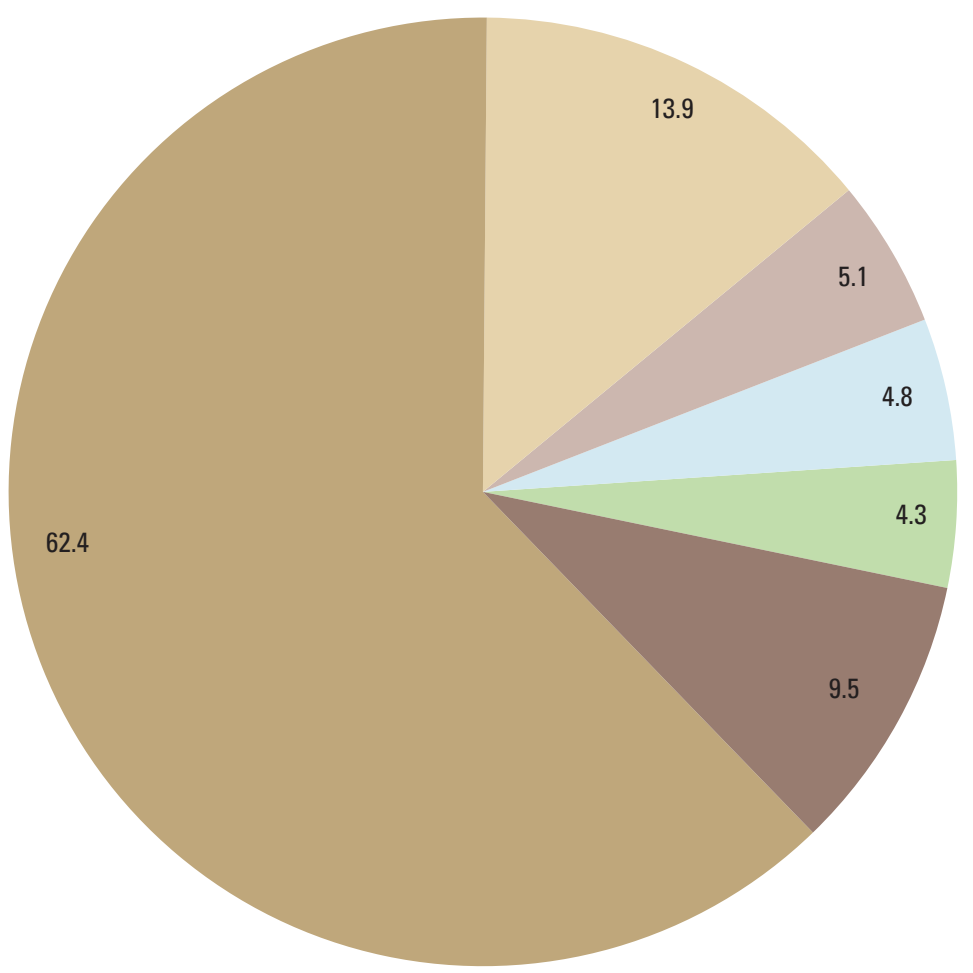

EXPLANATION

estern Interior Plains confining system, model layer 1

Springfield Plateau aquifer, model layer 2

Upper Ozark aquifer, model layer 4

Middle Ozark aquifer, model layer 5

Lower Ozark aquifer, model layer 6

St. Francois aquifer, model layers 8 and 9

B

Arkansas

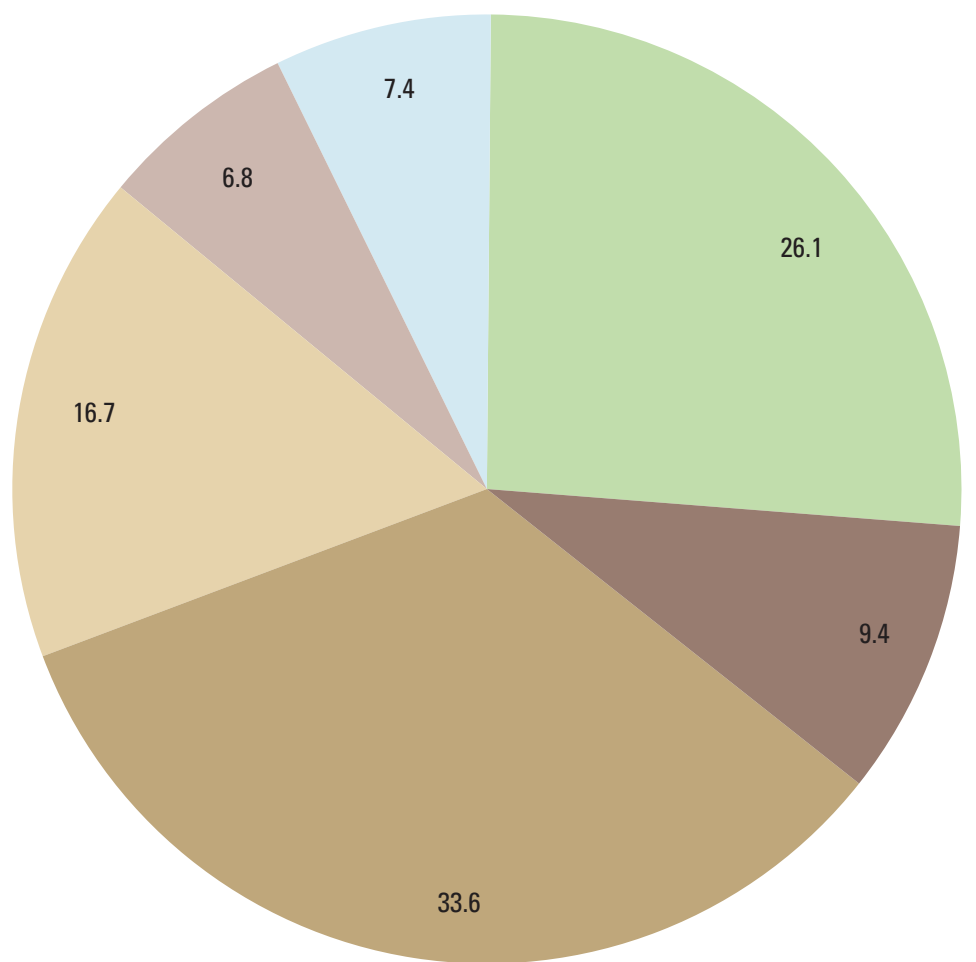

\section{EXPLANATION}

Western Interior Plains confining system, model layer 1 Springfield Plateau aquifer, model layer 2

Upper Ozark aquifer, model layer 4

Middle Ozark aquifer, model layer 5

Lower Ozark aquifer, model layer 6

St. Francois aquifer, model layers 8 and 9

Figure 7. Distribution of groundwater withdrawals by percentage in summer 2010 by hydrogeologic unit and model layer for $A$, the Ozark Plateaus aquifer system and each geographic area in the Ozark Plateaus aquifer system: $B$, Arkansas, $C$, Kansas, $D$, Oklahoma, $E$, Missouri, and $F$, southwest Missouri. 
C
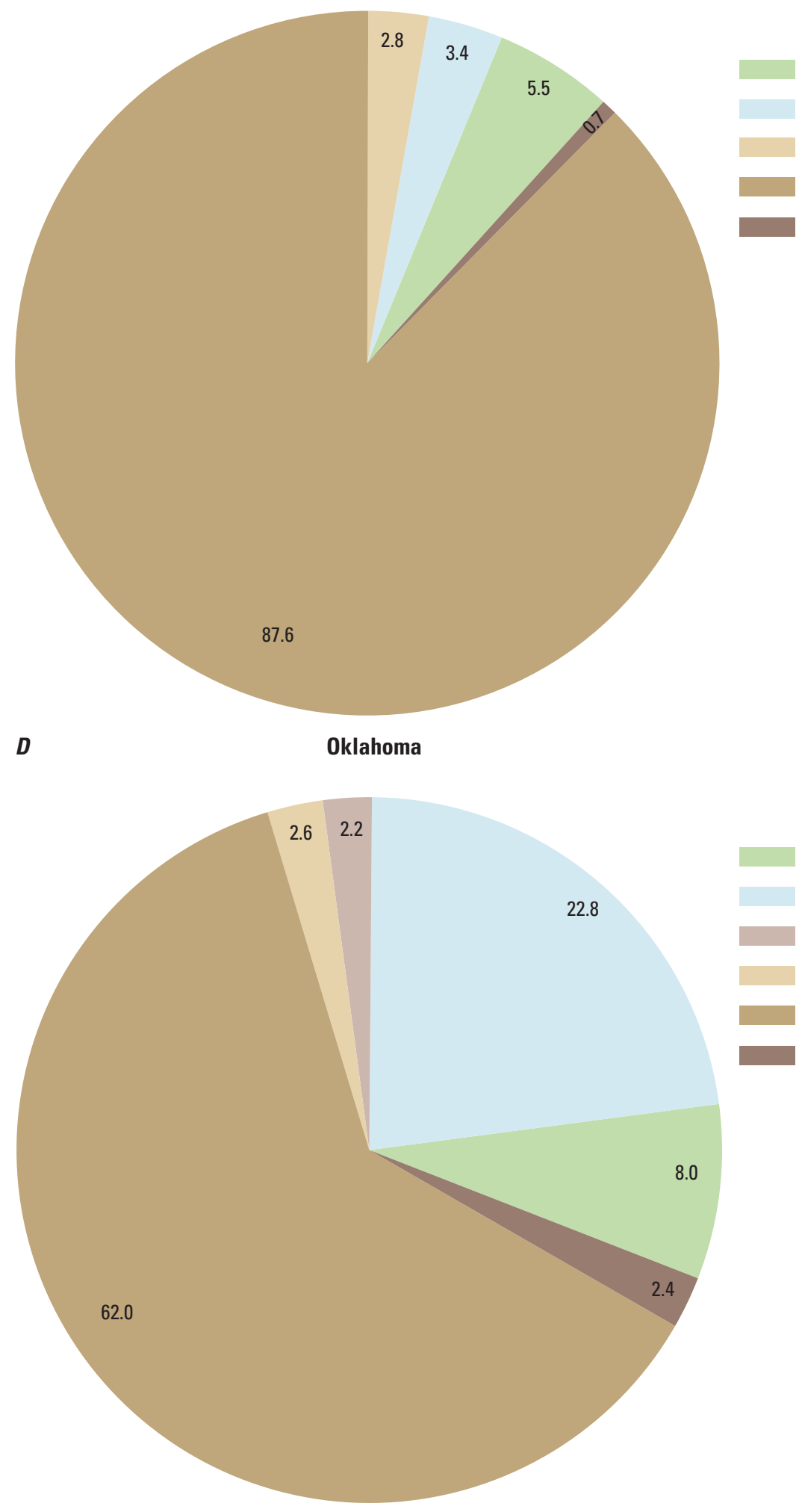

\section{EXPLANATION}

Western Interior Plains confining system, model layer 1

Springfield Plateau aquifer, model layer 2

Middle Ozark aquifer, model layer 5

Lower Ozark aquifer, model layer 6

St. Francois aquifer, model layers 8 and 9

\section{EXPLANATION}

Western Interior Plains confining system, model layer 1 Springfield Plateau aquifer, model layer 2

Upper Ozark aquifer, model layer 4

Middle Ozark aquifer, model layer 5

Lower Ozark aquifer, model layer 6

St. Francois aquifer, model layers 8 and 9

Figure 7. Distribution of groundwater withdrawals by percentage in summer 2010 by hydrogeologic unit and model layer for $A$, the Ozark Plateaus aquifer system and each geographic area in the Ozark Plateaus aquifer system: $B$, Arkansas, $C$, Kansas, D, Oklahoma, E, Missouri, and F, southwest Missouri.-Continued 
Missouri

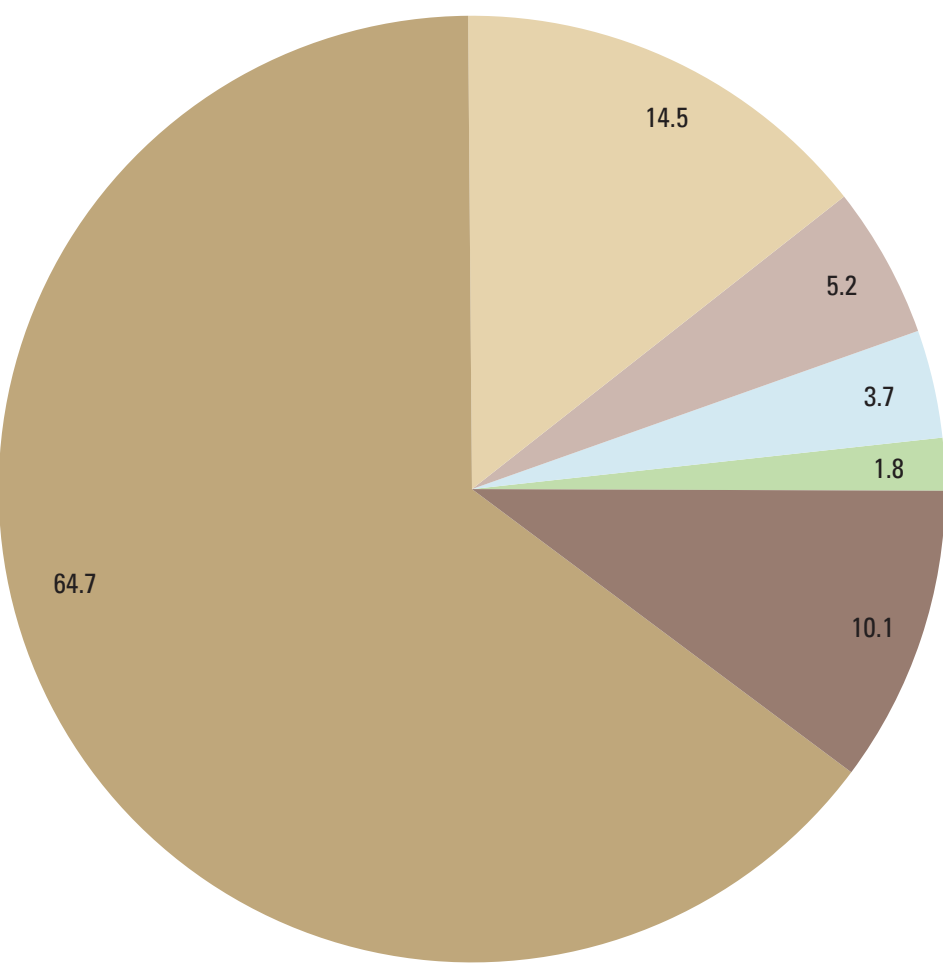

$\boldsymbol{F}$

Southwest Missouri

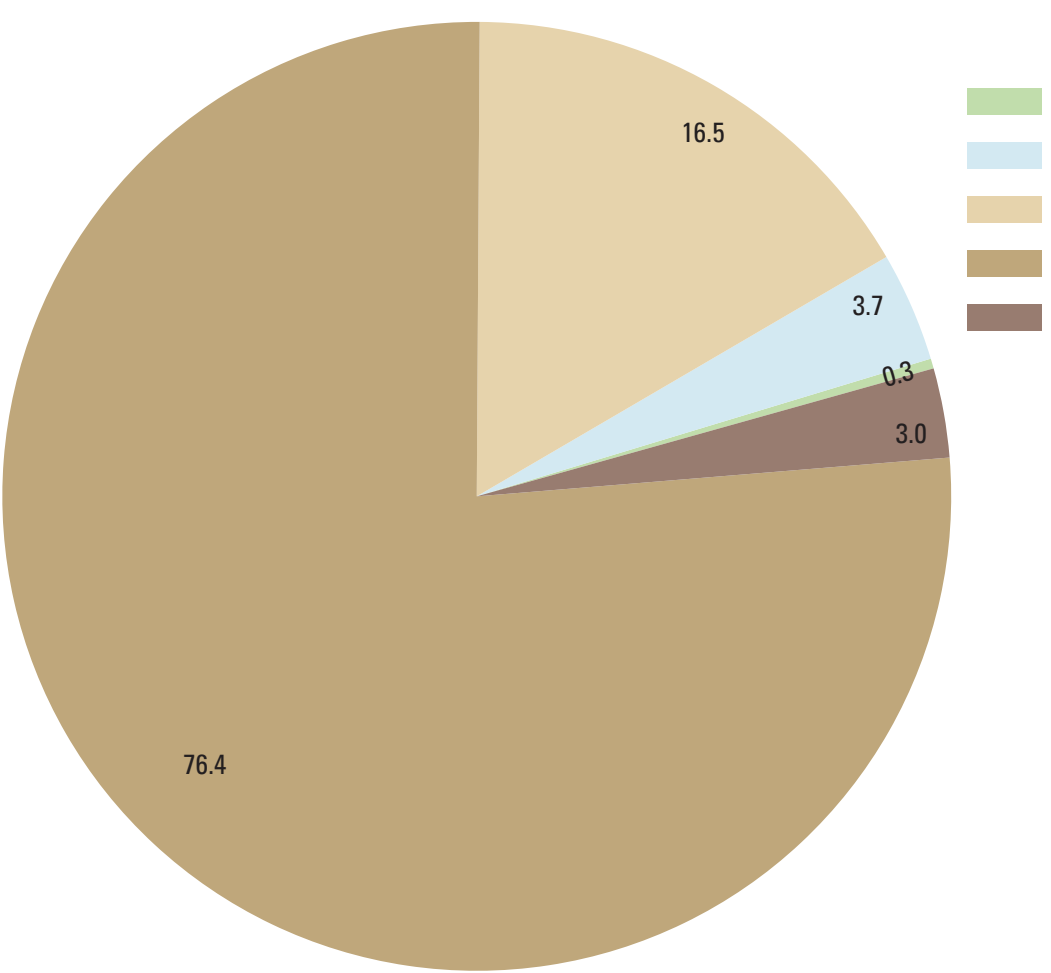

\section{EXPLANATION}

Western Interior Plains confining system, model layer 1

Springfield Plateau aquifer, model layer 2

Upper Ozark aquifer, model layer 4

Middle Ozark aquifer, model layer 5

Lower Ozark aquifer, model layer 6

St. Francois aquifer, model layers 8 and 9

\section{EXPLANATION}

Western Interior Plains confining system, model layer 1 Springfield Plateau aquifer, model layer 2

Middle Ozark aquifer, model layer 5

Lower Ozark aquifer, model layer 6

St. Francois aquifer, model layers 8 and 9

Figure 7. Distribution of groundwater withdrawals by percentage in summer 2010 by hydrogeologic unit and model layer for $A$, the Ozark Plateaus aquifer system and each geographic area in the Ozark Plateaus aquifer system: $B$, Arkansas, $C$, Kansas, $D$, Oklahoma, $E$, Missouri, and $F$, southwest Missouri.-Continued 

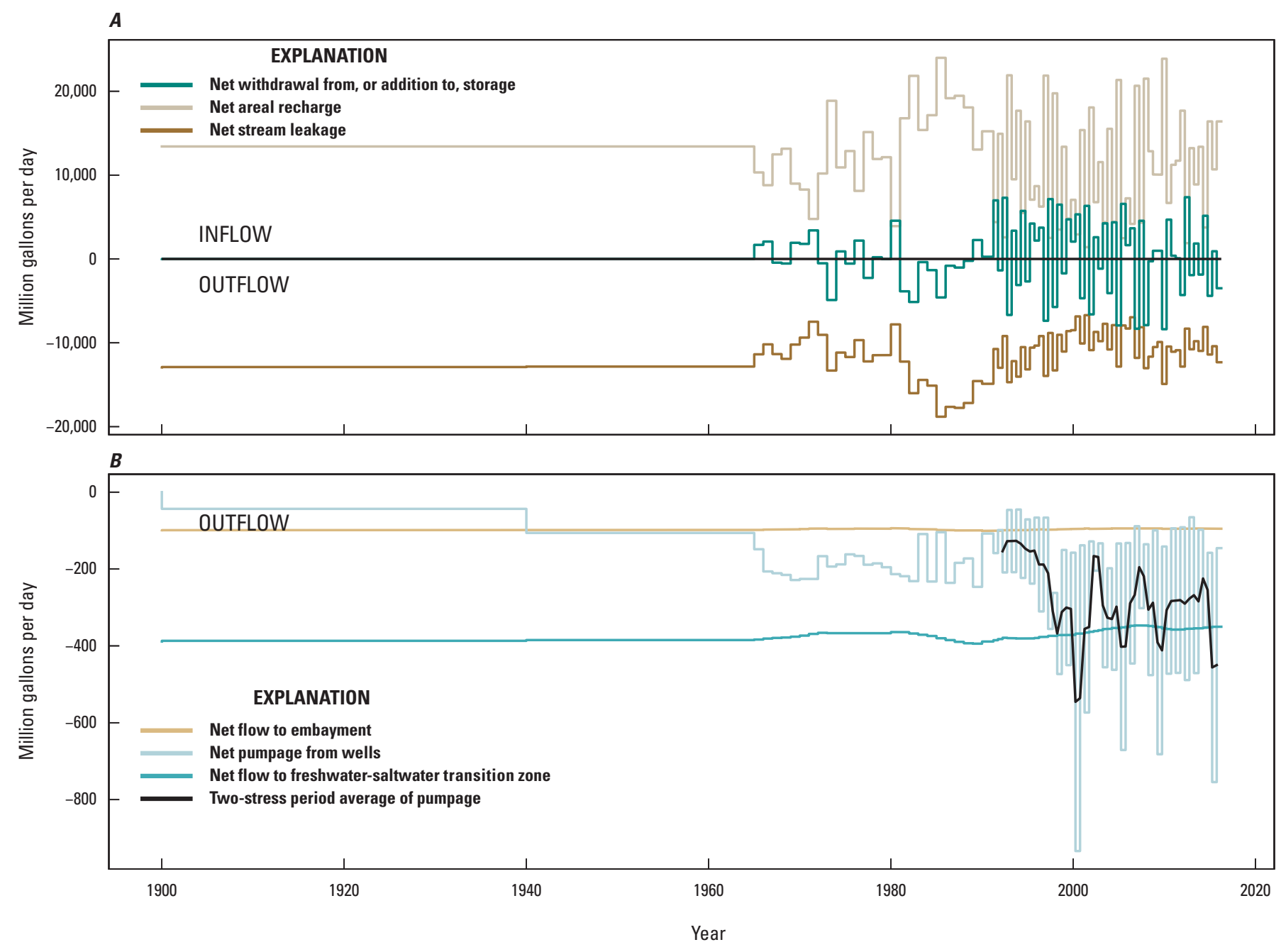

Figure 8. Groundwater-flow budget for Ozark model version 1.1 of $A$, large water-budget components and $B$, small water-budget components. 

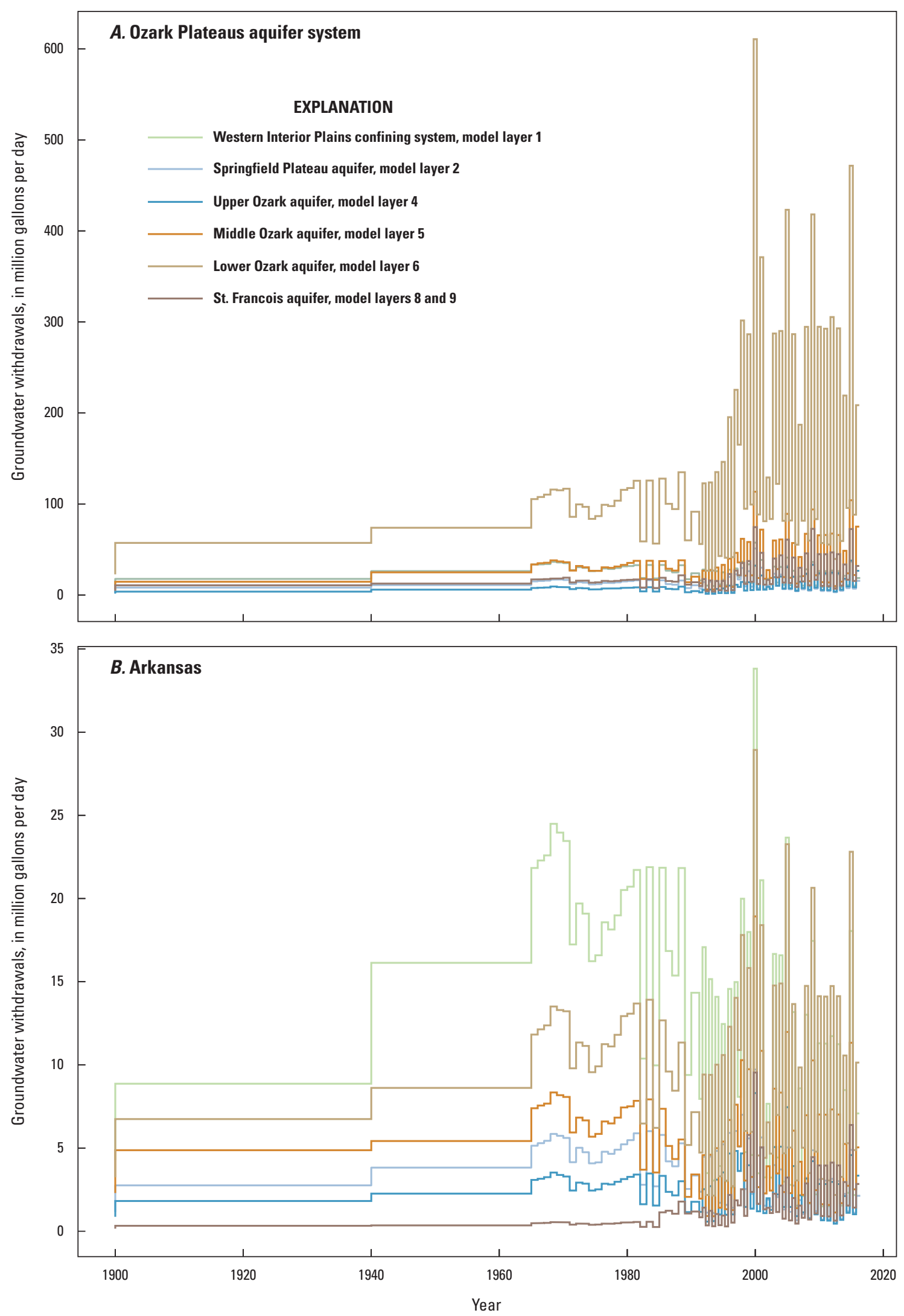

Figure 9. Distribution of groundwater withdrawals by regional aquifer for $A$, the Ozark Plateaus aquifer system and each geographic area in the Ozark Plateaus aquifer system: $B$, Arkansas, $C$, Kansas, $D$, Oklahoma, $E$, Missouri, and $F$, southwest Missouri. 

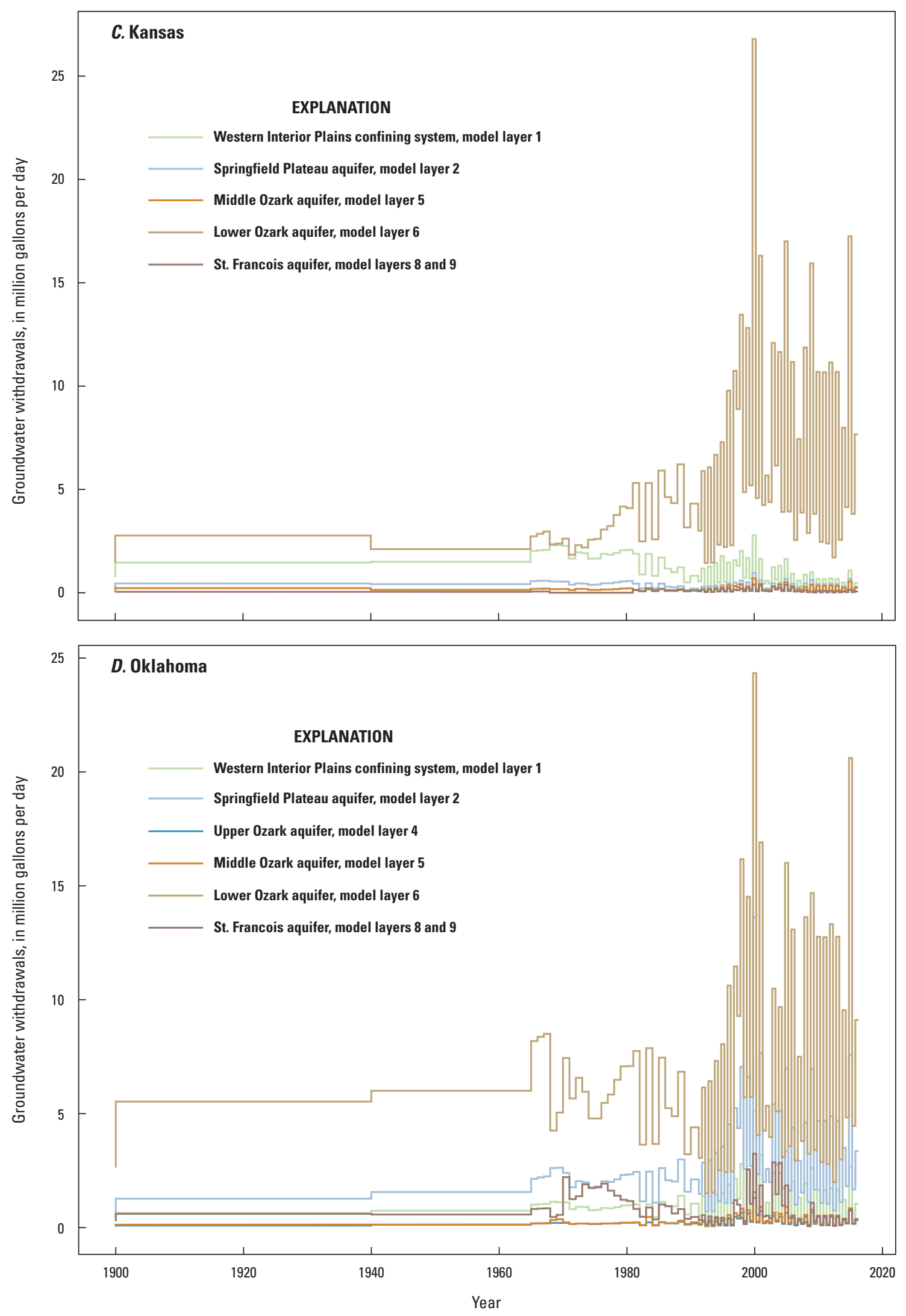

Figure 9. Distribution of groundwater withdrawals by regional aquifer for $A$, the Ozark Plateaus aquifer system and each geographic area in the Ozark Plateaus aquifer system: $B$, Arkansas, $C$, Kansas, $D$, Oklahoma, $E$, Missouri, and $F$, southwest Missouri.-Continued 

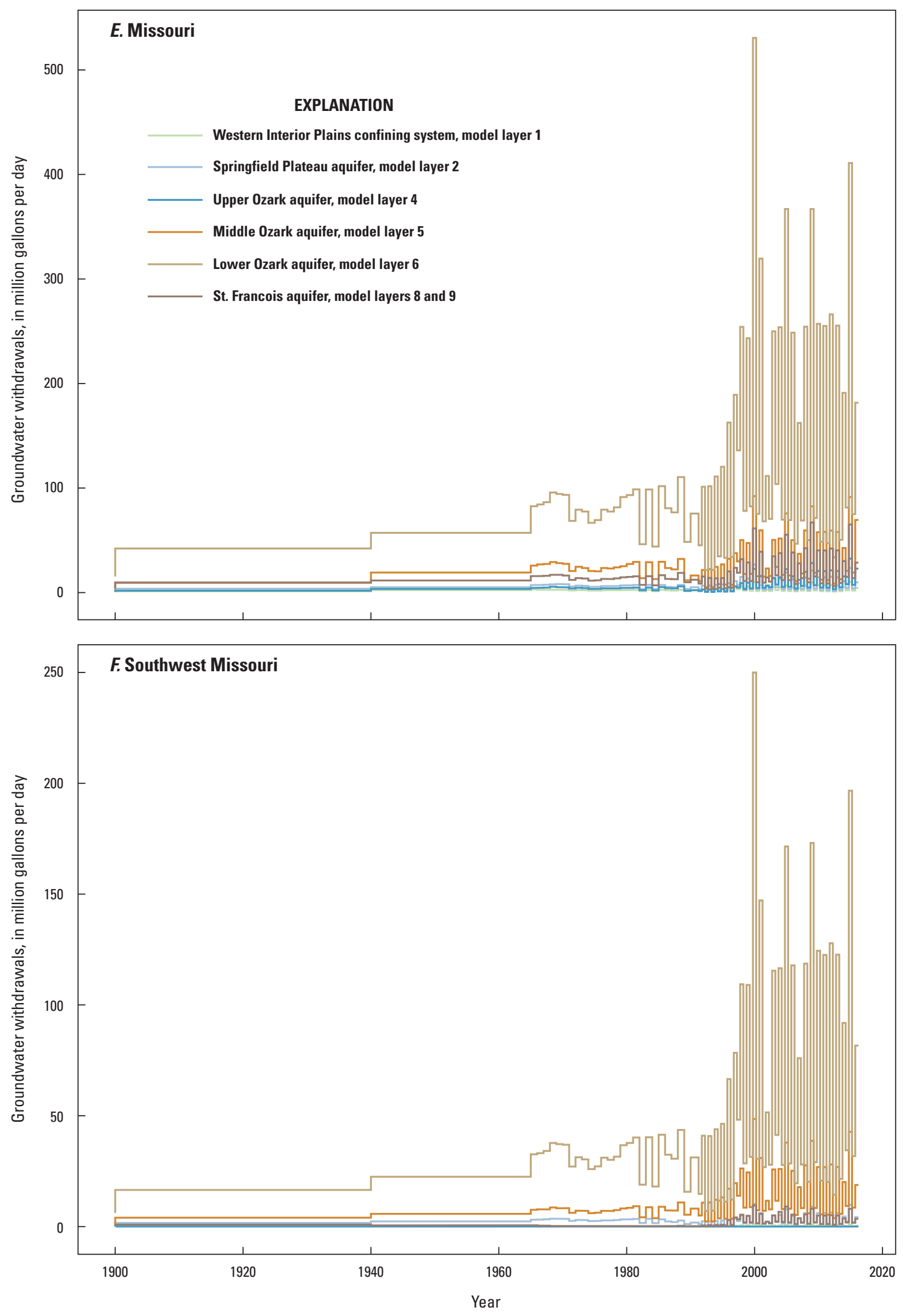

Figure 9. Distribution of groundwater withdrawals by regional aquifer for $A$, the Ozark Plateaus aquifer system and each geographic area in the Ozark Plateaus aquifer system: $B$, Arkansas, $C$, Kansas, $D, 0$ klahoma, $E$, Missouri, and $F$, southwest Missouri.-Continued 


\section{Changes in Groundwater Storage and Water Levels}

In general, cumulative storage change in the Ozark system appears to fluctuate from replenishment (loss of water from system) to extraction (gain of water to system) (fig. 10). The fluctuation in storage appears to be more closely linked to changes in recharge than pumping. When the cumulative departure from average recharge (where average recharge is $11.6 \mathrm{Bgal} / \mathrm{d}$ for the model period 1900 to 2016) is analyzed, recharge from predevelopment to 1965 is above average, and recharge from 1965 to about 1980 is below average (fig. 10A). Recharge is consistently above average from 1980 to about 1988, after which recharge declines through the mid-2000s. Conversely, groundwater withdrawals generally increase throughout the simulation (fig. 9), but the increase in aboveaverage pumping is steady until the late 1990s; the change in pumping does not appear to correlate with the change in storage over the same time period (fig. 10A).

Regionally, simulated changes in groundwater storage correspond more to changes in recharge than to increases in pumping (fig. 10). Prior to 1965, there is relatively little change in storage and pumping, and little to no change in water levels except for an area in northeastern Oklahoma where water levels declined by as much as $300 \mathrm{ft}$ (fig. 11). From 1965 to about 1980, a negative cumulative departure from average recharge results in groundwater release from storage (shown as positive cumulative departure from average in storage over that period on fig. 10), which corresponds to several localized declines in water levels (fig. 12). Some of the largest declines are in northeastern Oklahoma as a continuation of existing declines from historical pumping.
Christenson and others (1990) note that the first wells drilled in the lower Ozark aquifer in northeastern Oklahoma flowed at land surface, but by 1981 the water level was $471 \mathrm{ft}$ below land surface. From about 1980 to 1988, above-average recharge results in increased groundwater storage (shown as negative cumulative departure from average in storage on fig. 10) and groundwater levels (fig. 13). After 1988, groundwater is extracted from storage until about 2009, which corresponds to a positive slope in cumulative departure from average recharge, and after 2009, changes in storage fluctuate less dramatically (fig. 10A). The cumulative storage change until 2009 results in groundwater-level declines similar to those seen in 1980, though the declines are larger in magnitude and in spatial scope for the areas of northeastern Oklahoma and southwestern Missouri (fig. 14), where some water levels decline more than $400 \mathrm{ft}$ from predevelopment.

Though the largest area of water-level declines occurs in southwestern Missouri (fig. 13), the change in water level does not necessarily correspond to a comparably large change in storage. When comparing the area of southwestern Missouri to the entire model area, cumulative storage change is less than 500 billion gallons, compared to cumulative pumping amounts of more than 1,500 billion gallons by the end of the calibration period (March 31, 2016), likely because the groundwater in this part of the Ozark system is under confined aquifer conditions. Storage values tend to be low, ranging from $3.29 \times 10^{-7}$ to $4.7 \times 10^{-5} 1 / \mathrm{ft}$, under confined aquifer conditions, corresponding to findings by Hays and others (2016): "Because of the relatively minor volume of groundwater stored in the carbonate units, declines in aquifer recharge, such as occur during periods of drought, can create substantial decreases in water availability at seasonal time scales."

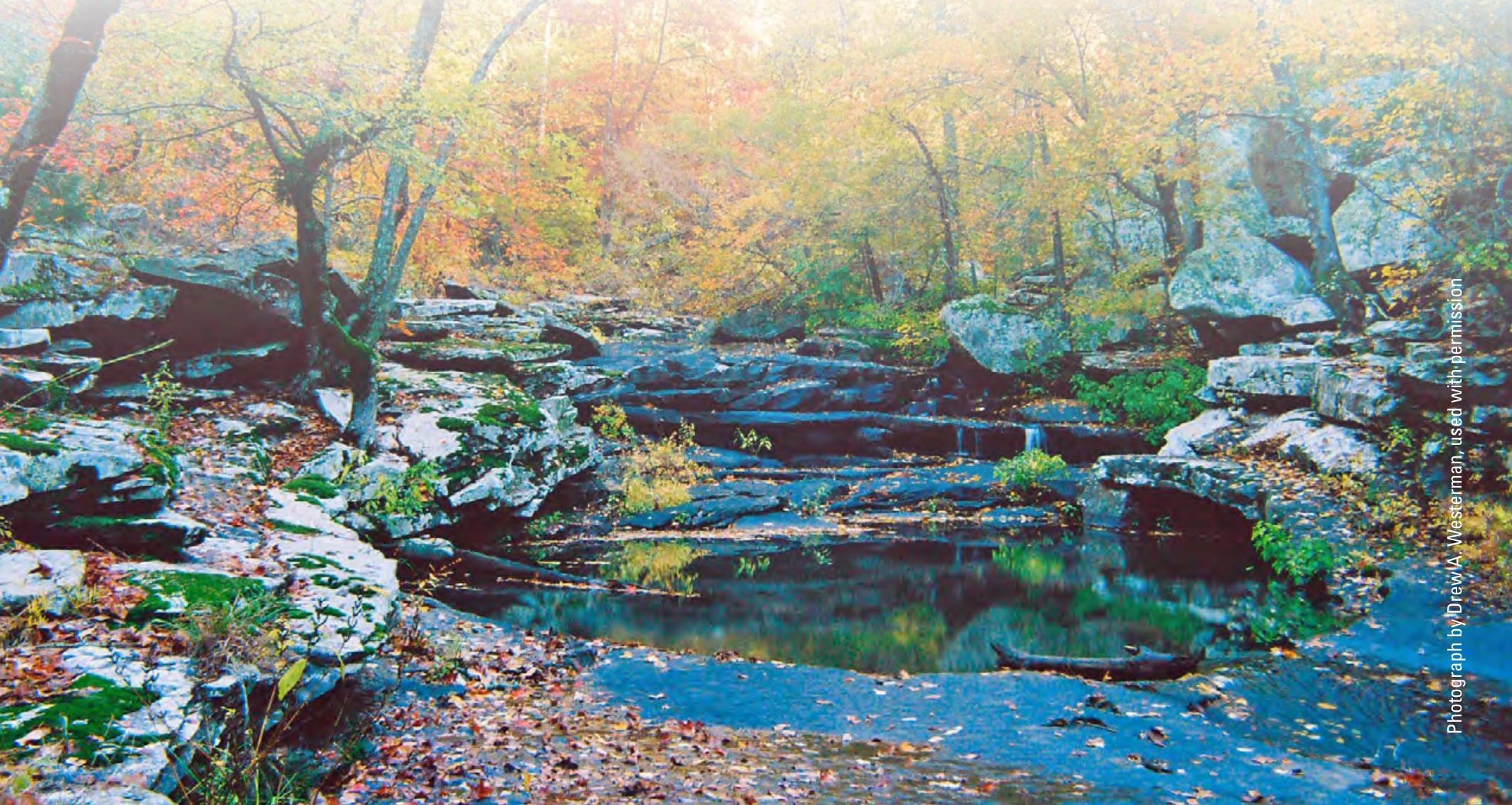



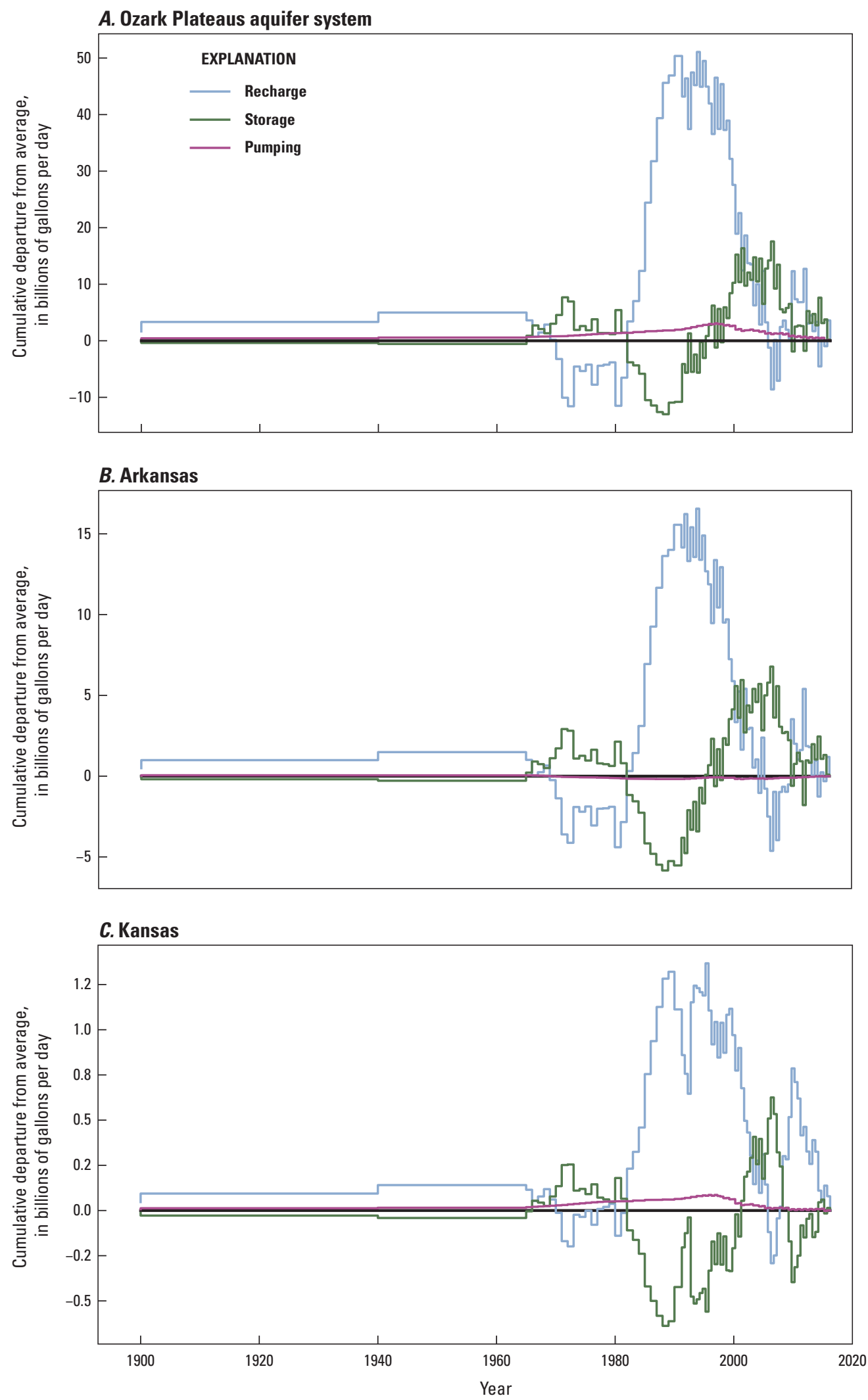

Figure 10. Cumulative recharge, pumping, and storage for $A$, the Ozark Plateaus aquifer system and each geographic area in the Ozark Plateaus aquifer system: $B$, Arkansas, $C$, Kansas, $D, 0$ klahoma, $E$, Missouri, and $F$, southwest Missouri. 

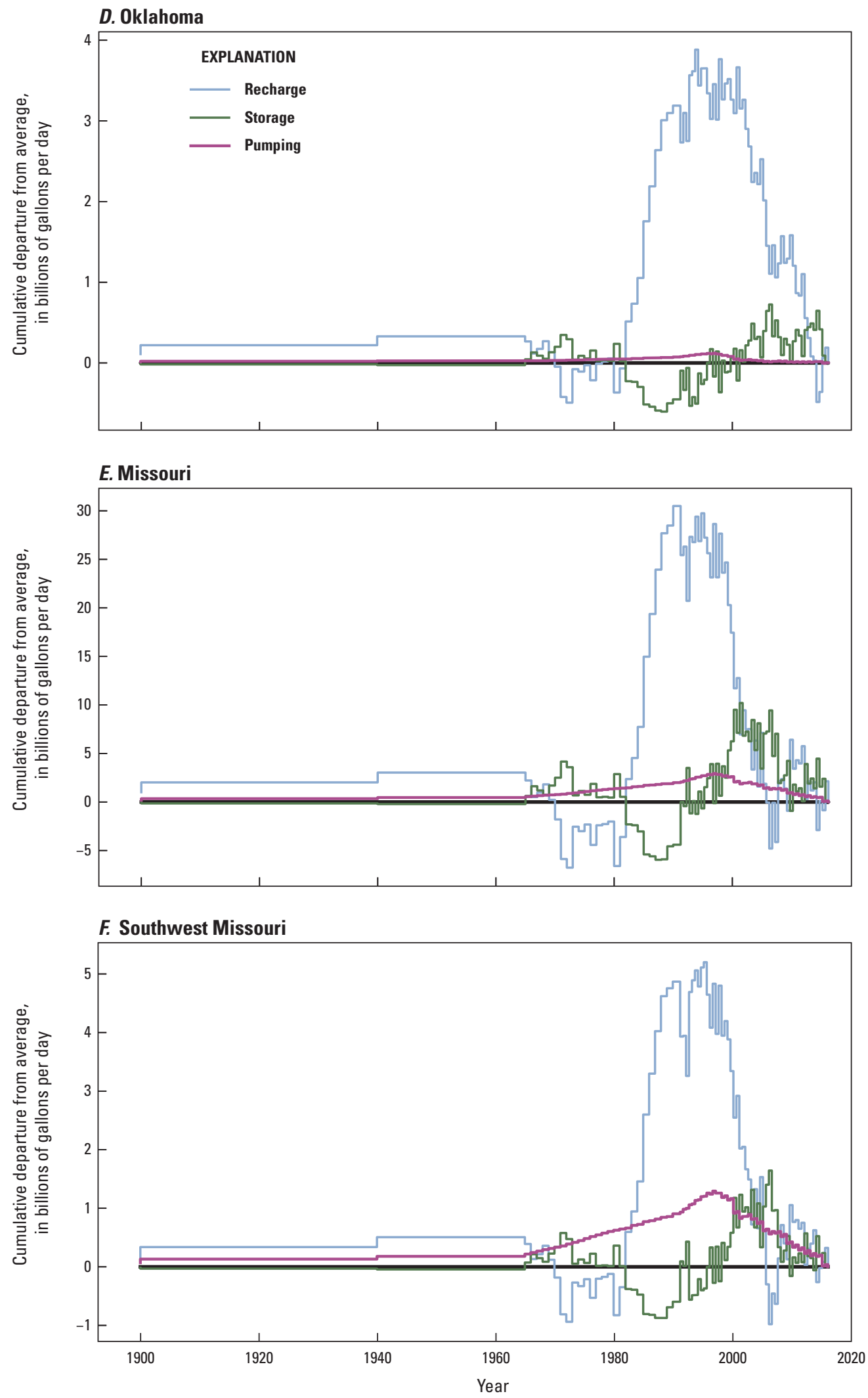

Figure 10. Cumulative recharge, pumping, and storage for $A$, the Ozark Plateaus aquifer system and each geographic area in the Ozark Plateaus aquifer system: $B$, Arkansas, $C$, Kansas, $D$, Oklahoma, $E$, Missouri, and $F$, southwest Missouri.-Continued 


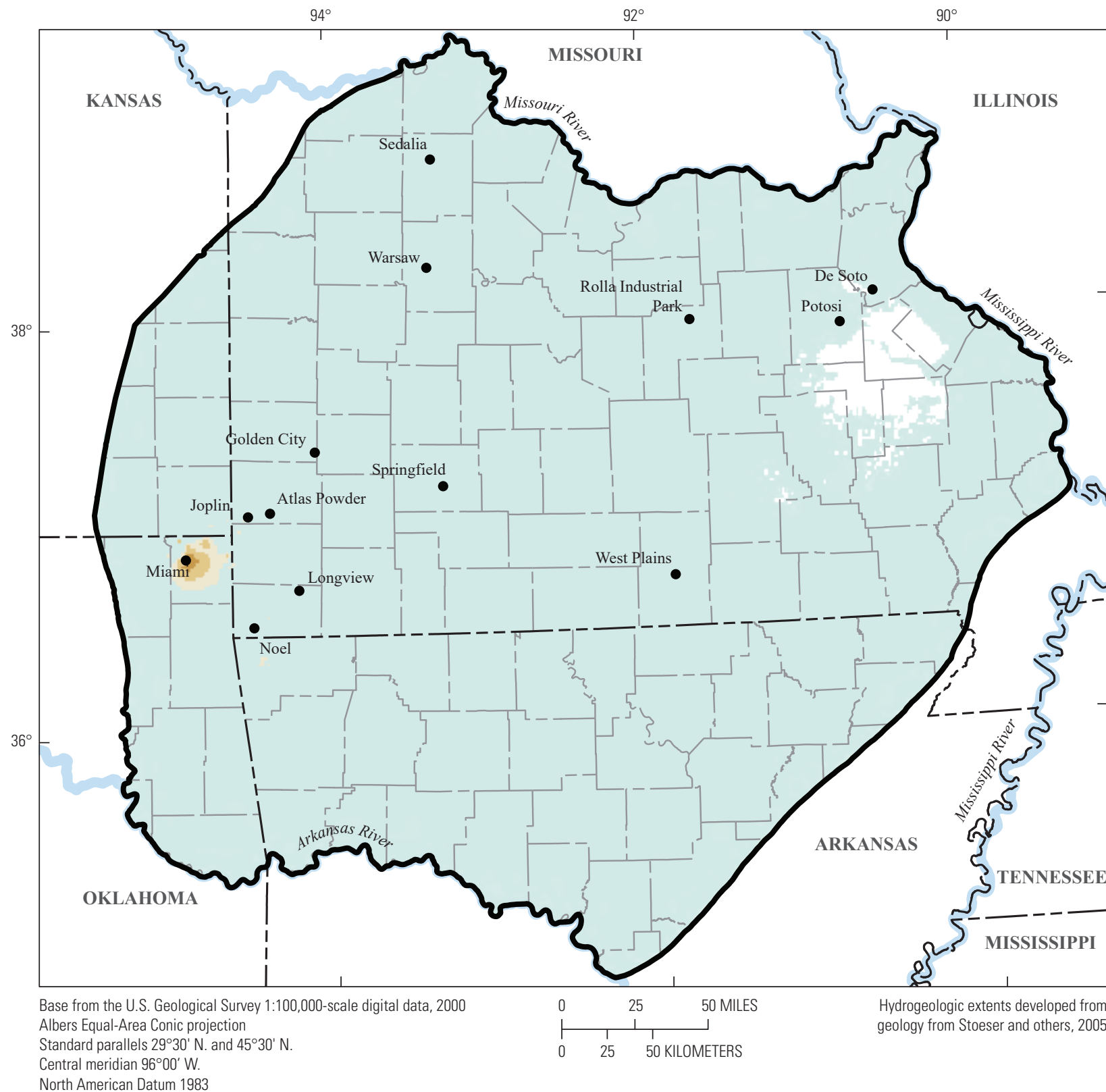

\section{EXPLANATION}

Water-level change from

predevelopment to 1965 , in feet

$<-400$

-200 to -399

-100 to -199

-50 to -99

-1 to -49

0 to 24

25 to 49

50 to 100

\section{No flow}

Note: White areas inside

no-flow boundary indicate

unit not present

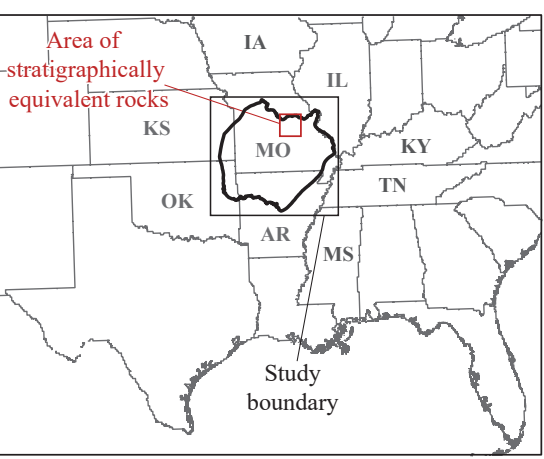

Figure 11. Water-level change from predevelopment to 1965 for the Ozark Plateaus aquifer system. 


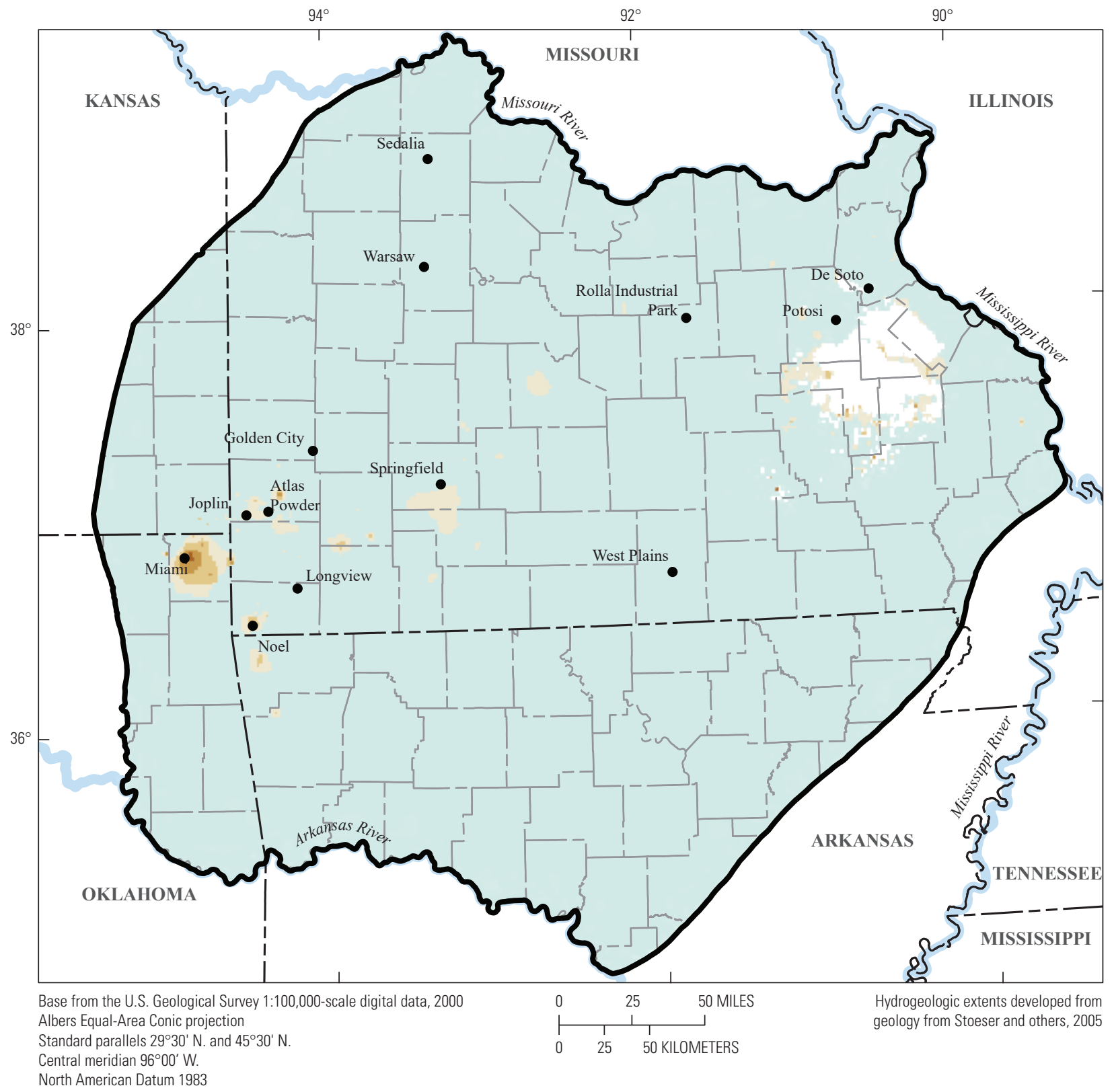

\section{EXPLANATION}

Water-level change from

predevelopment to 1980 , in feet

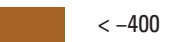

-200 to -399

-100 to -199

-50 to -99

-1 to -49

0 to 24

25 to 49

50 to 100

\section{No flow}

Note: White areas inside

o-flow boundary indicate

unit not present

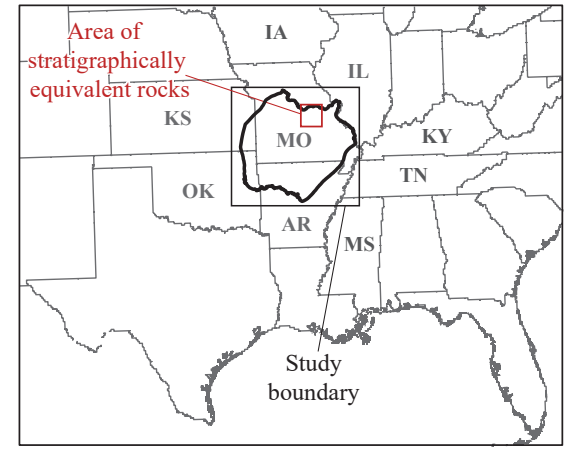

Figure 12. Water-level change from predevelopment to 1980 for the Ozark Plateaus aquifer system. 


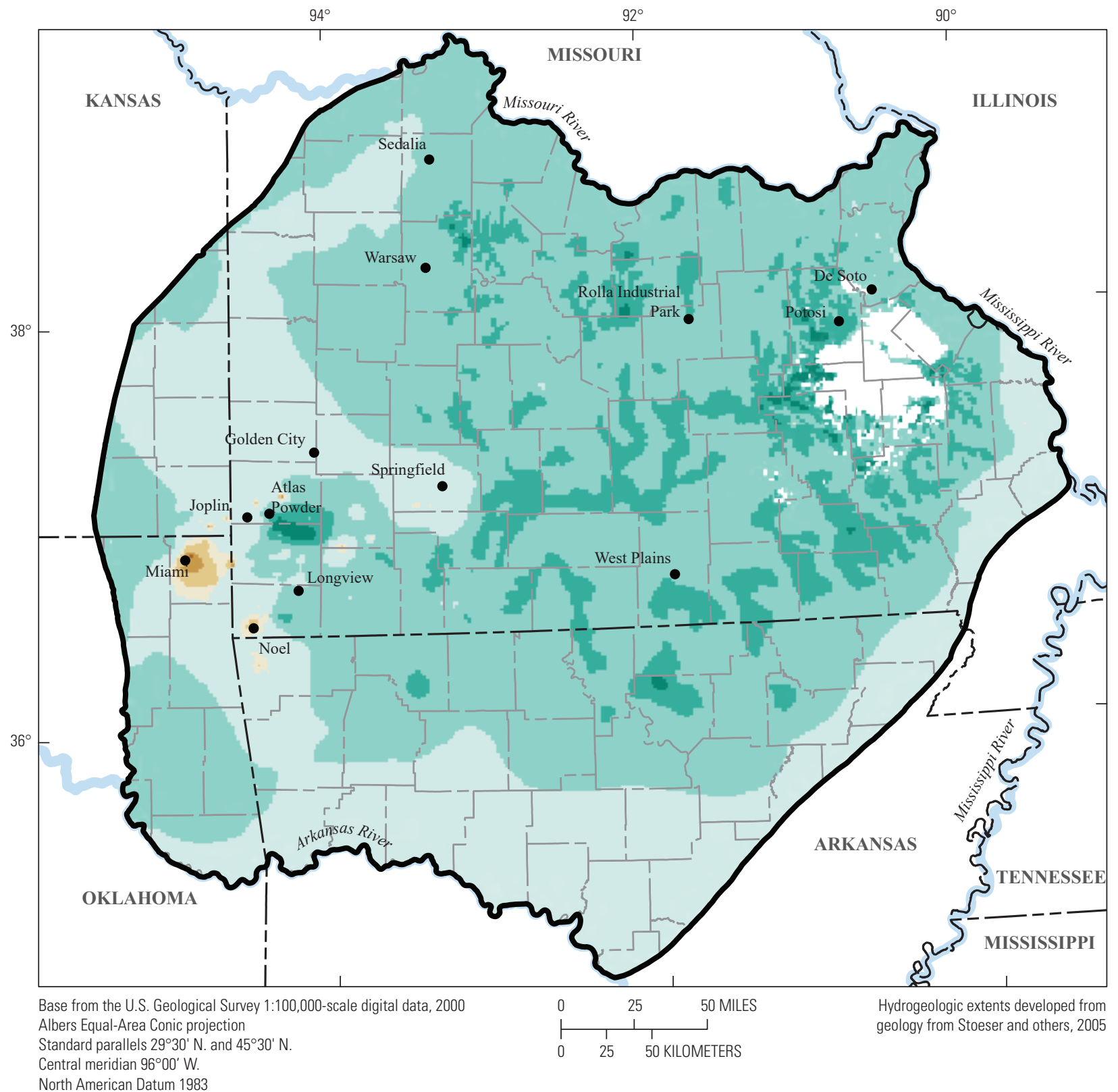

EXPLANATION

Water-level change from

predevelopment to 1988, in feet

$<-400$

-200 to -399

-100 to -199

-50 to -99

-1 to -49

0 to 24

25 to 49

50 to 100

\section{No flow}

Note: White areas inside

no-flow boundary indicate

unit not present

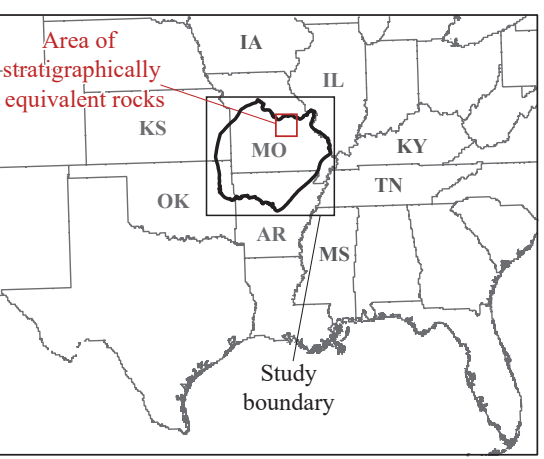

Figure 13. Water-level change from predevelopment to 1988 for the Ozark Plateaus aquifer system. 


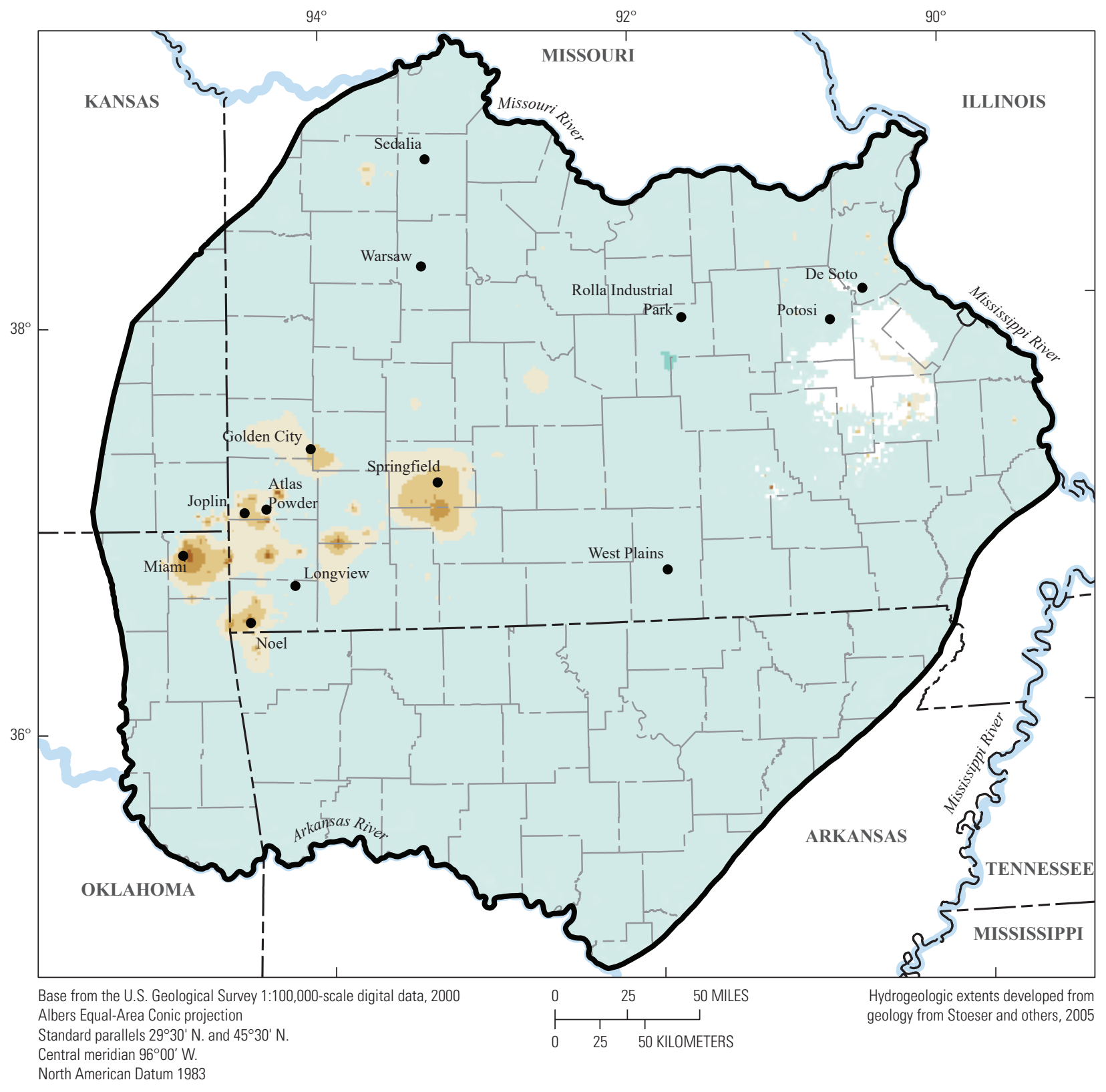

EXPLANATION

Water-level change from

predevelopment to 2009, in feet

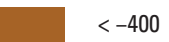

-200 to -399

-100 to -199

-50 to -99

-1 to -49

0 to 24

25 to 49

50 to 100

No flow

Note: White areas inside

no-flow boundary indicate

unit not present

Figure 14. Water-level change from predevelopment to 2009 for the Ozark Plateaus aquifer system. 


\section{Evaluation of Potential Future Conditions}

The effects of variability in groundwater withdrawals and long-term climate change on the groundwater availability of the Ozark system are a concern for communities and resource managers in the area. Groundwater withdrawal varies from year to year, but is generally expected to increase with population, industrial, and agricultural needs. Most climate models predict warmer air temperatures by midcentury in the Ozark Plateaus area, especially from midspring through early fall (Alder and Hostetler, 2013). Less agreement on the magnitude of precipitation exists among climate models, although the multi-model average indicates near-historical amounts of total annual precipitation, with changes in timing, including slight increases in winter and spring precipitation (Alder and Hostetler, 2013). Additionally, the geographic division between the more arid western United States and more humid eastern United States at the 100th meridian is predicted to shift eastward (Seager and others, 2017), potentially affecting the hydrologic budget of the western extent of the Ozark system if aridity increases. While future changes in the amount of aquifer recharge appear uncertain, increasing temperatures, especially in the summer months, imply increasing water demand, and some climate models predict increases in the frequency and intensity of drought and the intensity of extreme precipitation events. In low-storage aquifers, such as the Ozark system, even short, intense periods of drought can cause large declines in water levels. Conversely, wet periods will correspond to relatively rapid recovery.

Three scenarios were developed to simulate potential future conditions and the potential effects on the hydrologic system and availability of groundwater resources. For each scenario, the inflow and outflow budget terms were extracted from the numerical model. Water-level change was evaluated from predevelopment to October 1, 2060. The 45-year future conditions period was divided into 89 stress periods, each 6 months in length-April through September (representing spring and summer pumping and recharge conditions) and October through March (representing fall and winter pumping and recharge conditions). The seasonal conditions were simulated to provide information on the range in storage that is affected by changes in pumping and recharge. For simplicity, each scenario is summarized as follows.

- Baseline scenario-extension of the average (1996 to 2016) seasonal pumping and recharge values.

- Pumping scenario - extension of the average (1996 to 2016) seasonal recharge values and increases in pumping following the historical trend for the period 2016-2060 of up to 120 percent of the 1996 to 2016 average seasonal pumping values.
- GCM scenario - extension of the average (1996 to 2016) seasonal pumping values and variable recharge based on seasonal averages of soil water storage from a water-balance model using temperature and precipitation data from multiple general circulation models.

\section{Baseline and Pumping Scenario Simulation Assumptions and Limitations}

The baseline scenario was developed by using average summer and winter recharge and average summer and winter pumping conditions from 1996 to 2016 as discussed in the section "Comparison of Postdevelopment Conditions between the Conceptualized and Simulated Systems." All other parameter values and boundary conditions remain constant for each winter and summer stress period throughout the 45-year simulation.

The pumping scenario used the same summer and winter recharge as the baseline scenario and pumping increased based on a second-order polynomial trend of historical pumping developed by Knierim and others (2017). Pumping rates were increased at all existing wells uniformly, though under actual future conditions, the number of wells would likely increase to extract the additional water. The errors in this formulation are somewhat mitigated because the model cells are 1 mile per side, so effectively, the model represents net conditions in each square mile. A limitation of using only existing wells is that the effects of installing wells in other parts of the study area or drilling into deeper aquifers are not represented.

\section{Climate Change Simulation Assumptions and Limitations}

To simulate the effects of climate change, a potential future scenario was developed in which recharge from April 2016 to October 2060 varied according to changes in soil water storage as predicted by the water-balance model of Hostetler and Alder (2016), referred to as WBM. The WBM simulates changes in the monthly water balance driven by the National Aeronautics and Space Administration Earth Exchange Downscaled Climate Projections (NEX-DCP30) temperature and precipitation data from 30 of the 5 th Climate Model Intercomparison Project (CMIP5) models. The 800-meter gridded NEX-DCP30 dataset represents statistically downscaled maximum and minimum air temperature and precipitation from the CMIP5 models (Thrasher and others, 2013). The WBM includes historical (1950-2005) and future (2006-2099) climate projections for two Representative Concentration Pathways (RCP) greenhouse gas (GHG) emission scenarios developed for the Fifth Assessment Report of the Intergovernmental Panel on Climate Change (2014). 
Soil water storage simulated by using climate projections for RCP4.5 was used as a surrogate for recharge. For the RCP4.5 emissions scenario, atmospheric GHG concentrations are stabilized such that a radiative equivalent of 4.5 watts per square meter (about 650 parts per million carbon dioxide $\left[\mathrm{CO}_{2}\right]$ equivalent) is not exceeded after the year 2100 . The gridded WBM dataset is available as bulk downloadable data (U.S. Geological Survey, 2018).

Estimates of recharge for model v1.1 were calculated by using a combination of methods, including annual regressionbased methods and temporal modification during the historymatching process through the use of multipliers as was done in model v1.0 (Clark and others, 2018). For the same historical period of the calibrated groundwater model and the WBM, soil water storage from the WBM was several orders of magnitude larger than recharge from the calibrated groundwater model. The soil water storage time series was therefore used to scale the calibrated groundwater model recharge for future (2016-2060) 6-month (summer or winter) stress periods, such that recharge was comparable across calibration and scenario periods.

$$
R_{w b m}=R_{a v g}\left(\frac{S W S_{s p}-S W S_{a v g}}{S W S_{a v g}}+1\right)
$$

where

$$
\begin{gathered}
R_{w b m} \quad \begin{array}{l}
\text { is the average (6-month) seasonal recharge, } \\
R_{a v g}
\end{array} \text { is the average (1996-2016) seasonal recharge } \\
\text { for model vl.1, }
\end{gathered}
$$

Recharge rates used in the GCM scenario were lower than recharge rates used in the baseline and pumping scenarios. The average summer recharge rate used in the GCM scenario was approximately half of that used in the baseline and pumping scenarios. Although lower, the average winter recharge rate used in the GCM scenario was much closer to that used in the baseline and pumping scenarios (approximately 90 percent). While summer and winter recharge rates used in the baseline and pumping scenarios remained constant over the 45 -year simulation period, recharge rates used in the GCM scenario decreased. The winter recharge rate used in the GCM scenario declined faster over the 45-year period than the summer recharge rate, at an approximate rate of $11 \mathrm{Mgal} / \mathrm{d}$ instead of $3 \mathrm{Mgal} / \mathrm{d}$, respectively.

\section{Scenario Evaluation}

The general patterns of water-level decline are similar for each scenario (figs. 15, 16, 17), but the greatest differences occur when climatic variation is simulated. For the baseline scenario, the areas of water-level decline in southwestern
Missouri and northeastern Oklahoma are only marginally different from those of 2009 (figs. 14, 15). In one area near head forecast 27, which is south of Springfield, Mo., the water-level decline from predevelopment is less in the baseline scenario than in 2009. Note that head forecasts are arbitrary numbers assigned to each head prediction for the purpose of differentiation and are discussed further in the section "Prediction Uncertainty." This water-level decline may be the extended result of a transition from groundwater use to surface-water supplies for a larger percentage of the demand in the area. Because stresses and recharge in the baseline scenario are on a constant winter/summer cycle for 45 years based on the average values from 1996 to 2016 (fig. 18A), the system approaches a new dynamic equilibrium. Reaching pseudo-equilibrium in a relatively short amount of time in groundwater systems with low storage capacity is not uncommon. This is reflected when evaluating the cumulative storage from 2016 to 2060; while seasonal fluctuation in storage continues, the overall storage change appears to gradually flatten, particularly for the Ozark aquifer (fig. 19B).

Areas of water-level decline in the pumping scenario are generally more expansive, and the decline is of greater magnitude with depth (fig. 16). Most areas of decline in southwestern Missouri, northeastern Oklahoma, and northwestern Arkansas are connected by an area of decline greater than $50 \mathrm{ft}$. Cumulative storage change for the pumping scenario increased from that of the baseline scenario, and the trend in storage depletion continues to increase slightly from 2016 through the end of the simulation as a result of continued increases in pumping (figs. 18B, 20).

More areas of water-level decline are evident in the GCM scenario compared to the baseline or pumping scenarios, though the magnitude of the depth is less than in the pumping scenario in many areas (fig. 17). Storage changes in the GCM scenario vary both seasonally and annually in response to short-term fluctuations in recharge (figs., 18C, 21). Overall storage change in the GCM scenario is greater than in the baseline and pumping scenarios, with a maximum cumulative depletion of about 4,000 billion gallons in the Ozark system (fig. 21A). The greatest storage depletion of the GCM scenario occurs within the Ozark aquifer and the Western Interior Plains confining system, likely because the changes in recharge directly affect the units with the largest area of exposed rock throughout the model area. Though the magnitude of water-level declines appears less in the GCM scenario than in the other scenarios for the Ozark aquifer, the amount of water removed from storage is greater because of the unconfined conditions of the units and the broad areal extent of the declines. 

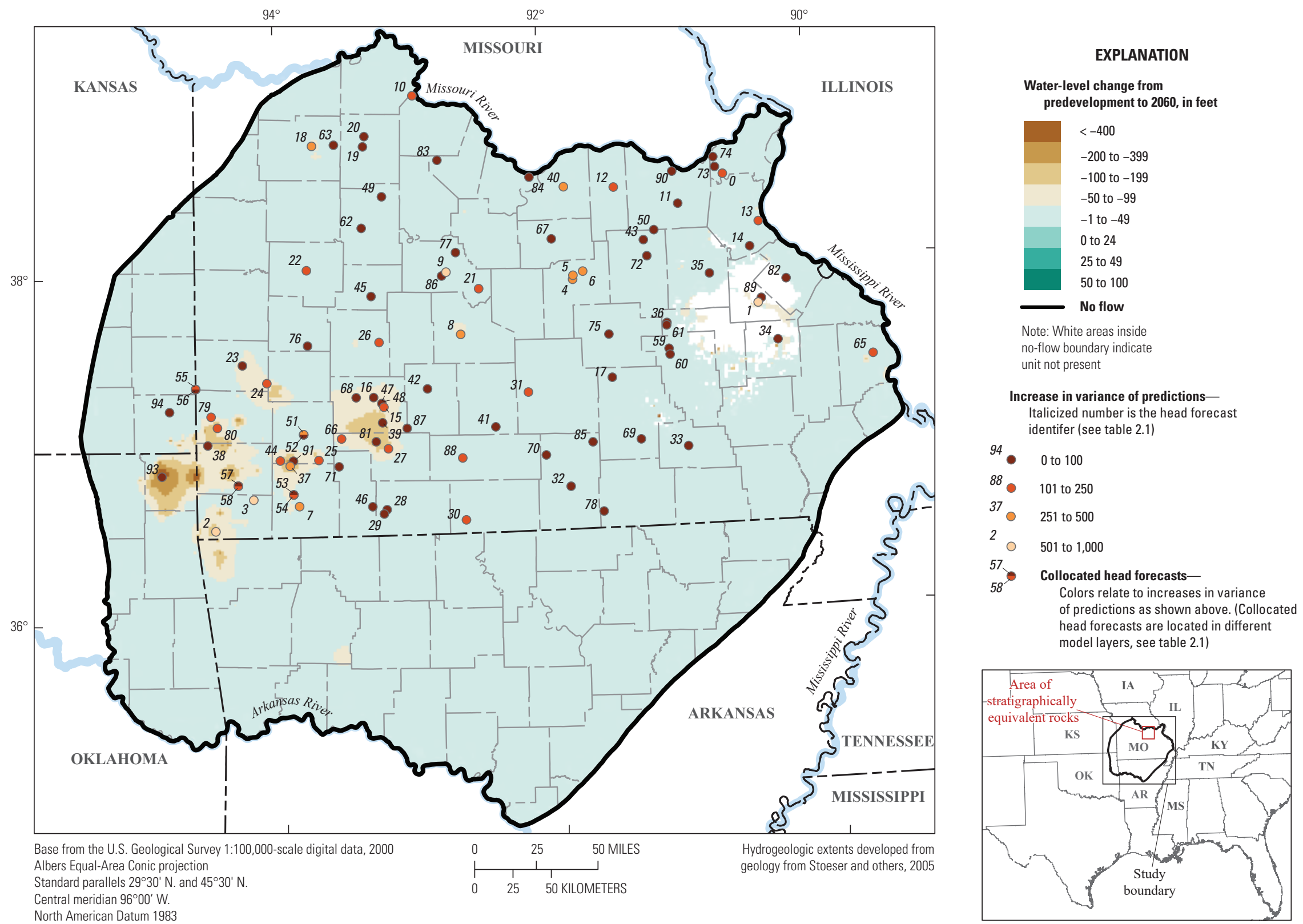

Figure 15. Water-level change from predevelopment to 2060 for the Ozark Plateaus aquifer for the baseline scenario. For each forecast location (as identified by head forecast identifier), summative percent increase in variance for predicted water levels at all forecast locations, when observation(s) at this location are excluded from the history matching dataset. Head forecast identifiers are arbitrary numbers assigned to each head prediction for the purpose of differentiation. See table 2.1 for head forecast identifier and associated model layer. 


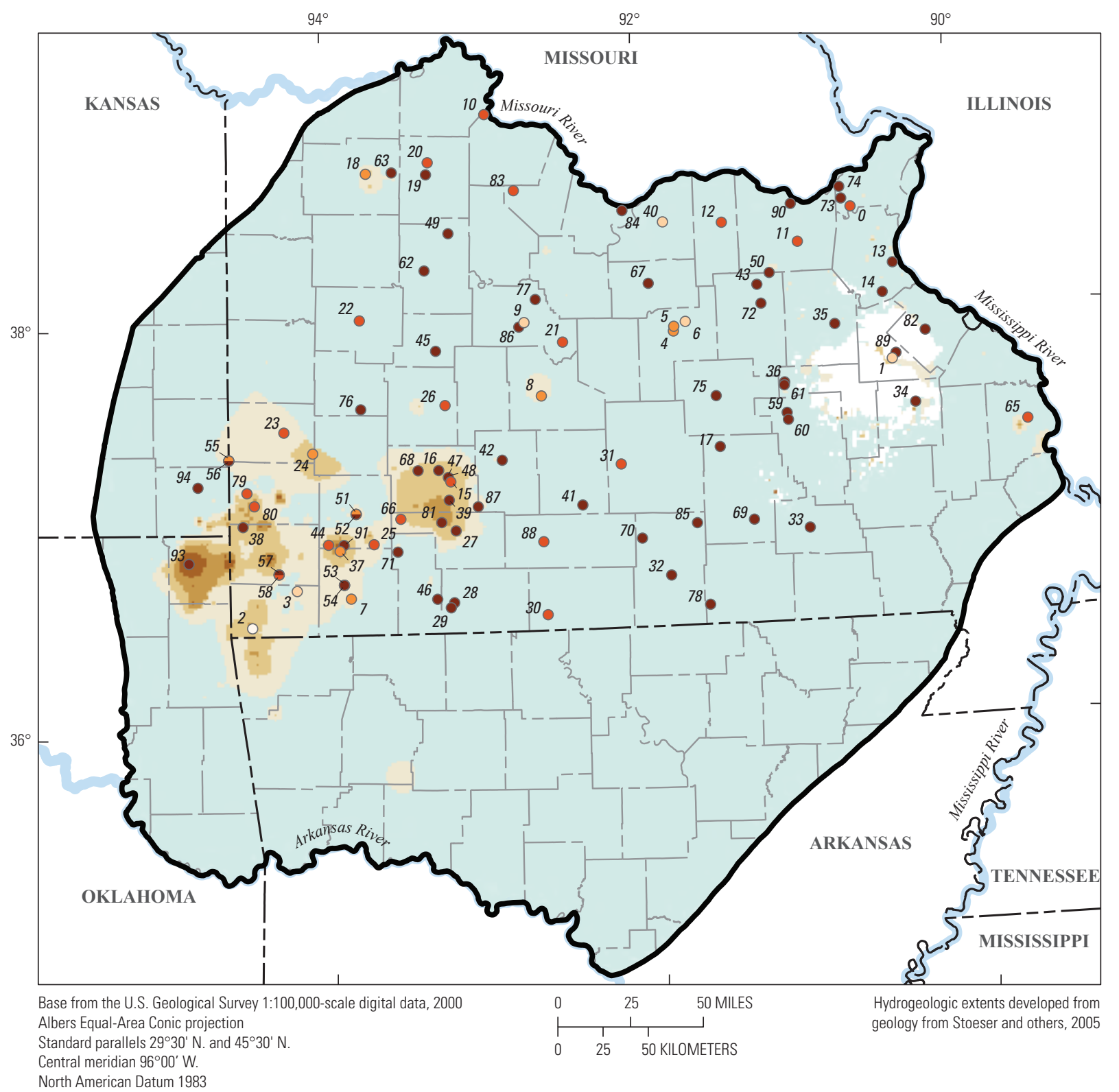

EXPLANATION

Water-level change from predevelopment to 2060, in feet

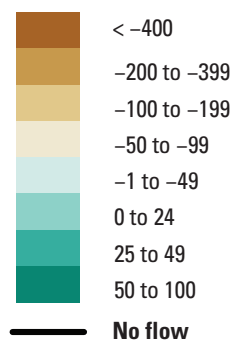

Note: White areas inside

no-flow boundary indicate

unit not present

Increase in variance of predictionstalicized number is the head forecast identifer (see table 2.1)

94 - 0 to 100

88 @ 101 to 250

37 ○ 251 to 500

40 ○ 501 to 1,000

2 ○ 1,001 to 1,146

${ }_{58}^{57}$ Collocated head forecasts -

ases in variance predictions as shown above. (Collocated head forecasts are located in different model layers, see table 2.1)

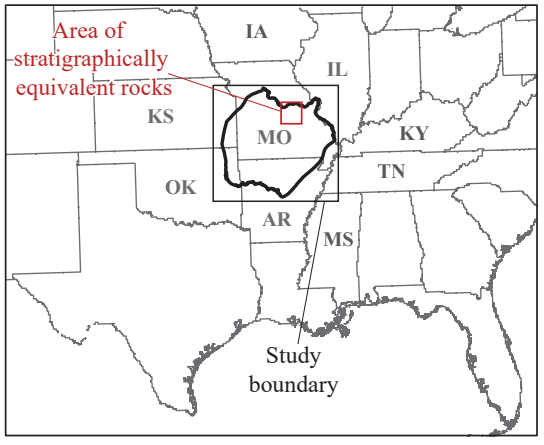

Figure 16. Water-level change from predevelopment to 2060 for the Ozark Plateaus aquifer for the pumping scenario. For each forecast location (as identified by head forecast identifier), summative percent increase in variance for predicted water levels at all forecast locations, when observation(s) at this location are excluded from the history matching dataset. Head forecast identifiers are arbitrary numbers assigned to each head prediction for the purpose of differentiation. See table 2.1 for head forecast identifier and associated model layer. 


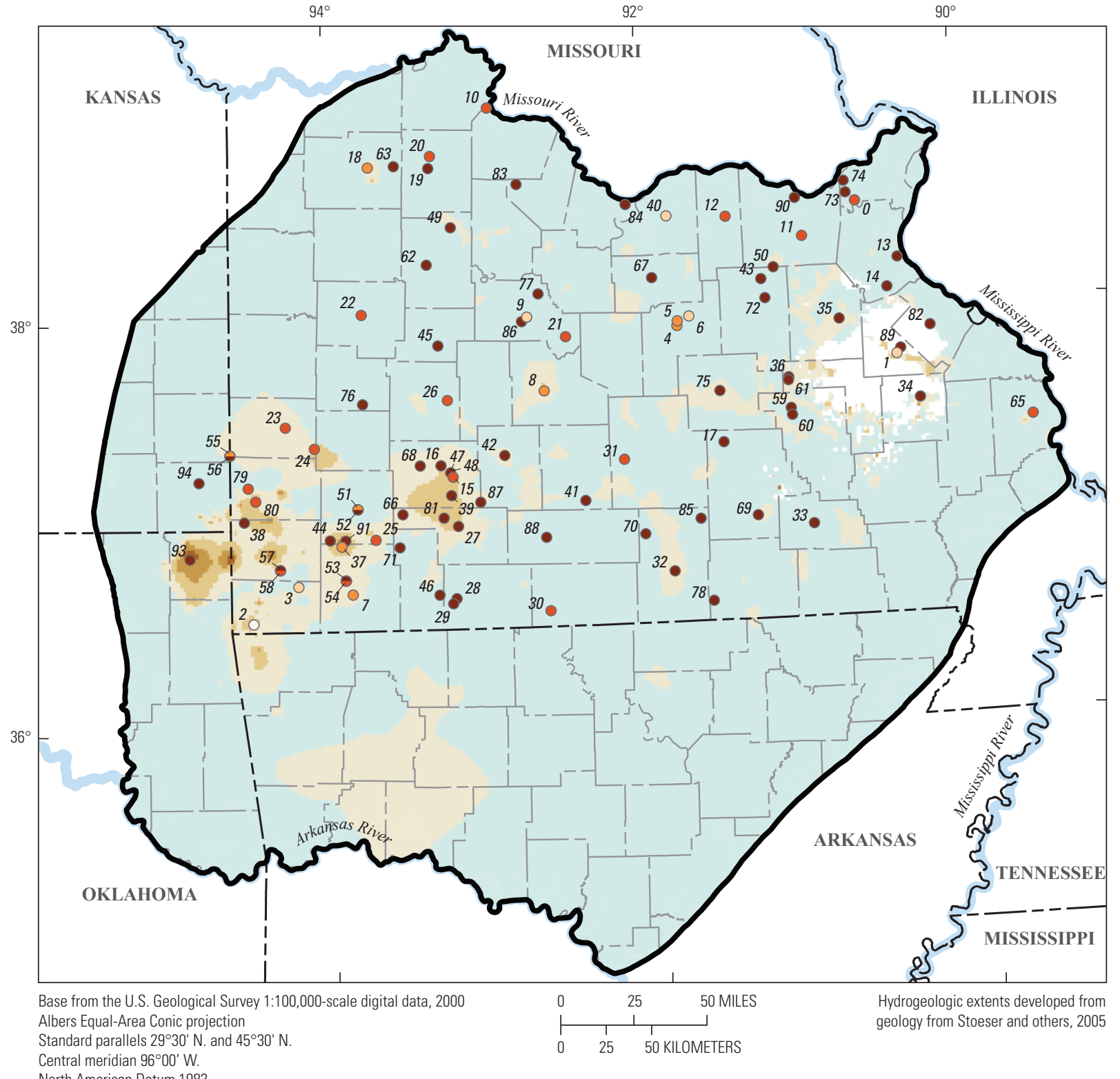

\section{EXPLANATION}

Water-level change from predevelopment to 2060, in feet

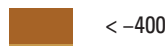

-200 to -399

-100 to -199

-50 to -99

0 to 24

25 to 49

50 to 100

No flow

Note: White areas inside

no-flow boundary indicate

unit not present

Increase in variance of predictions -

alicized number is the head forecast

identifer (see table 2.1)

94 - 0 to 100

30 — 101 to 250

8 ○ 251 to 500

1 ○ 501 to 1,000

2 ○ 1,001 to 1,146

Collocated head forecasts -

Colors relate to increases in variance of predictions as shown above. (Collocated head forecasts are located in different model layers, see table 2.1)

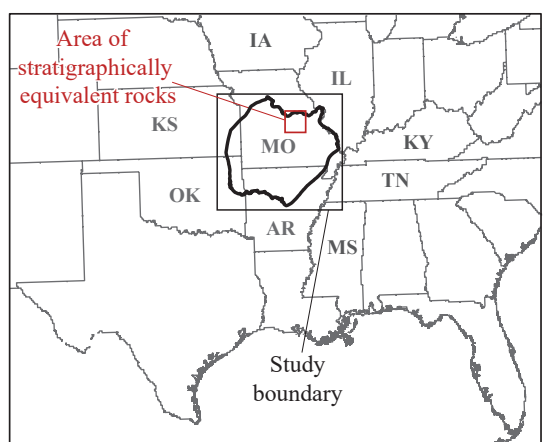

Figure 17. Water-level change from predevelopment to 2060 for the Ozark Plateaus aquifer for the general circulation model scenario. For each forecast location (as identified by head forecast identifier), summative percent increase in variance for predicted water levels at all forecast locations, when observation(s) at this location are excluded from the history matching dataset. Head forecast identifiers are arbitrary numbers assigned to each head prediction for the purpose of differentiation. See table 2.1 for head forecast identifier and associated model layer. 

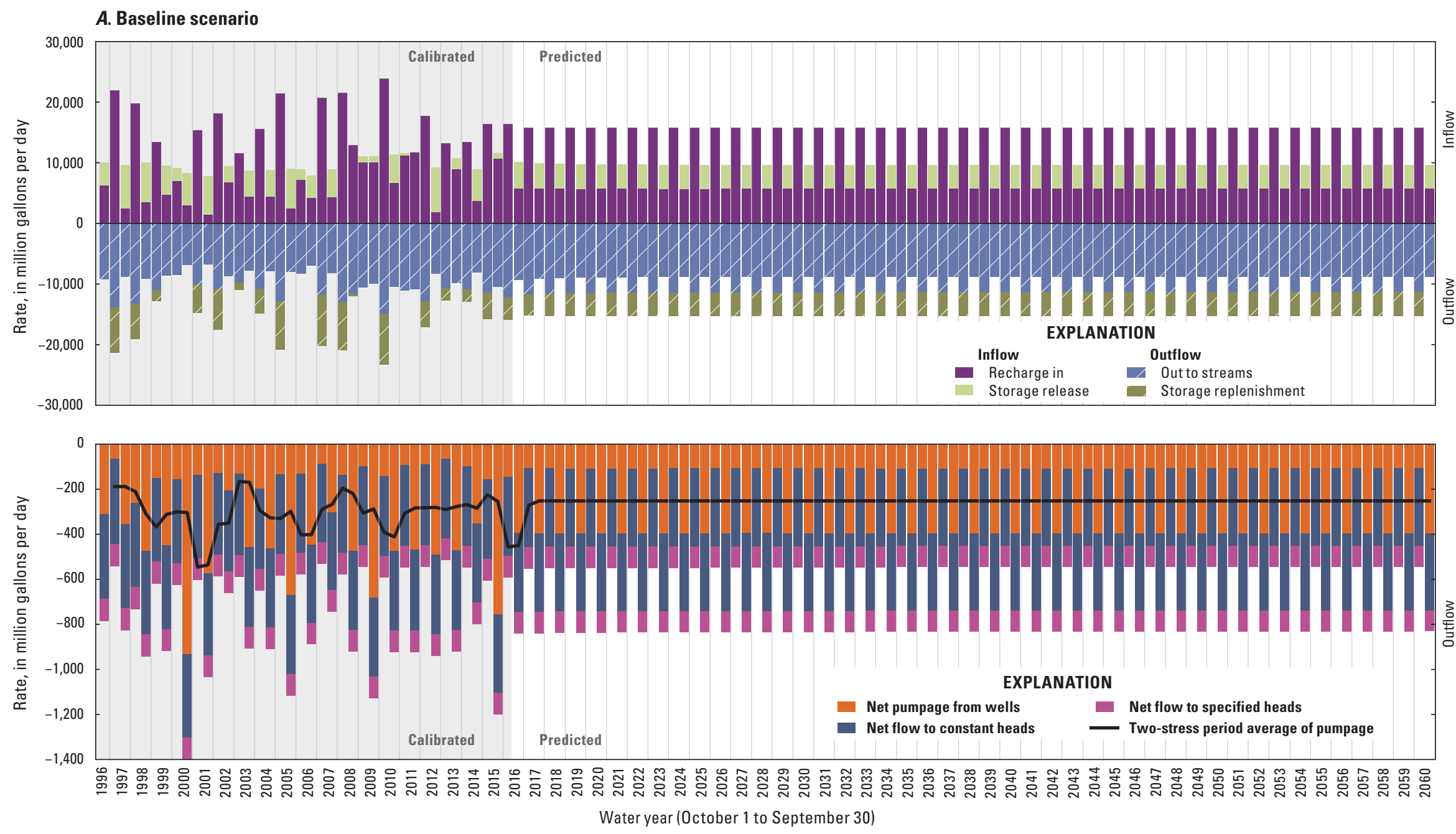

Figure 18. Hydrologic budget for each scenario developed to simulate potential future conditions from 2015 to 2060 in the Ozark Plateaus aquifer system: $A$, the baseline scenario, $B$, the pumping scenario, and $C$, the general circulation model scenario. 
B. Pumping scenario
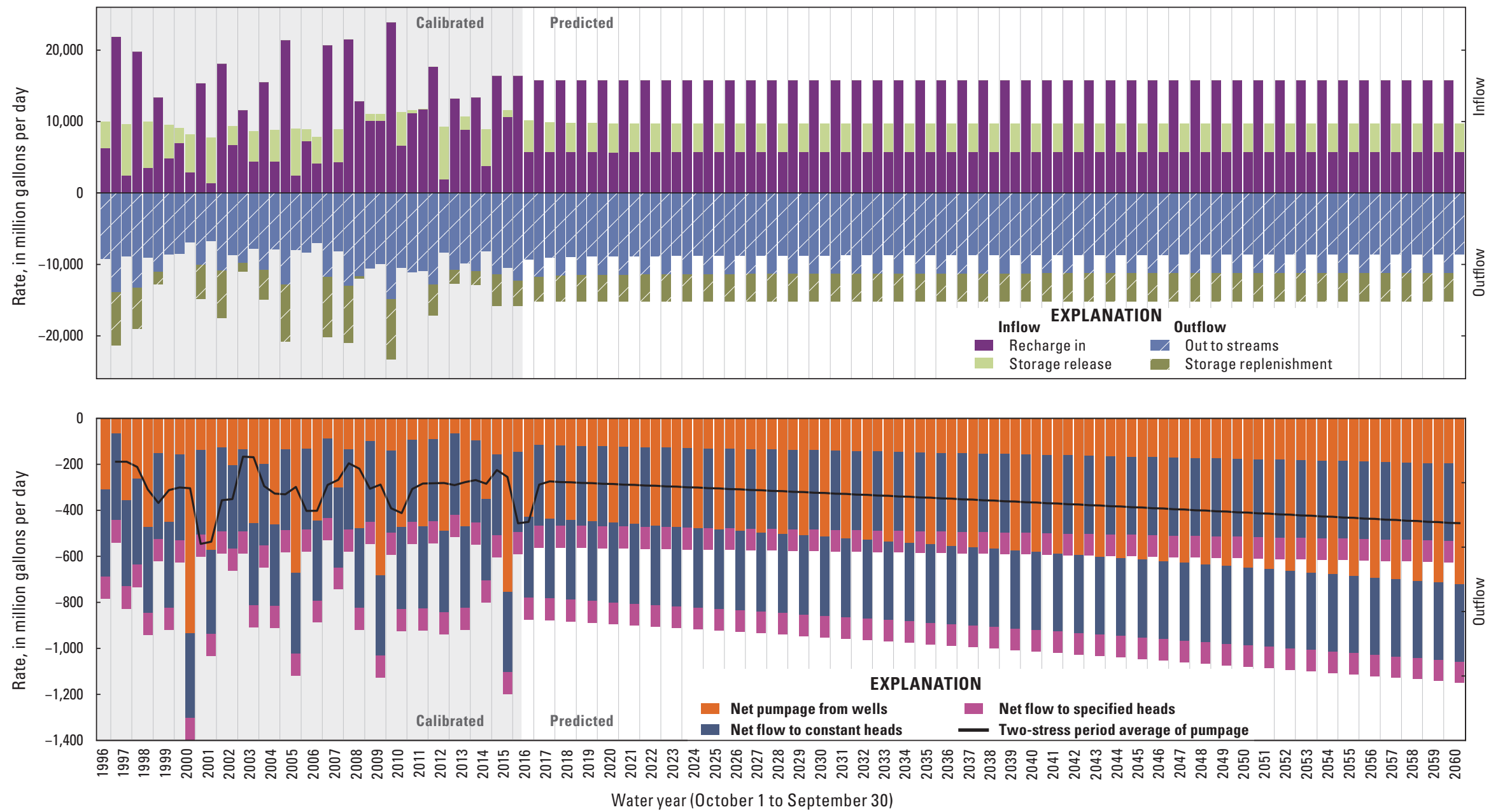

Figure 18. Hydrologic budget for each scenario developed to simulate potential future conditions from 2015 to 2060 in the Ozark Plateaus aquifer system: $A$, the baseline scenario, $B$, the pumping scenario, and $C$, the general circulation model scenario.-Continued 

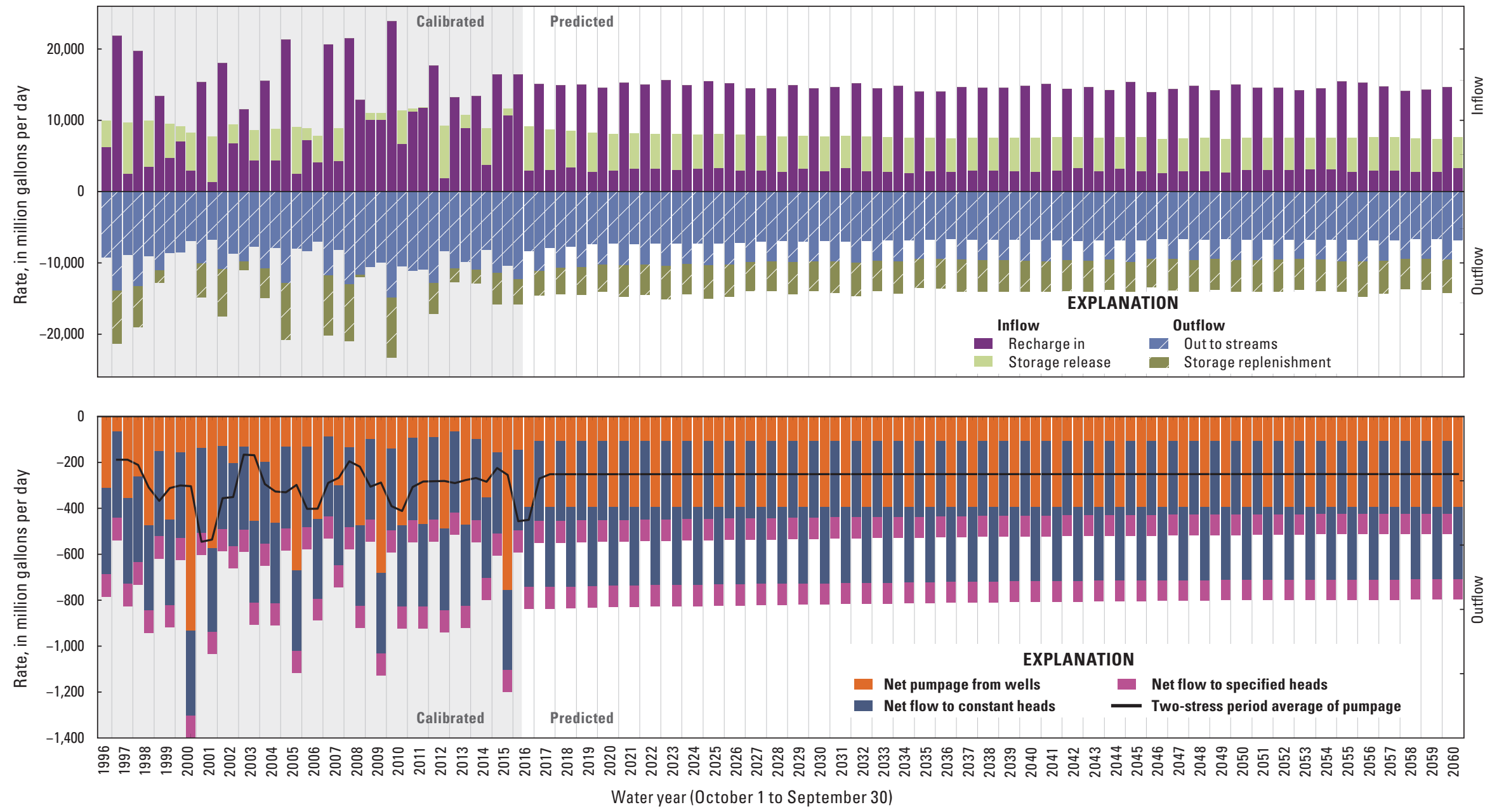

Figure 18. Hydrologic budget for each scenario developed to simulate potential future conditions from 2015 to 2060 in the Ozark Plateaus aquifer system: $A$, the baseline scenario, $B$, the pumping scenario, and $C$, the general circulation model scenario.-Continued 


\section{A. Ozark Plateaus aquifer system}

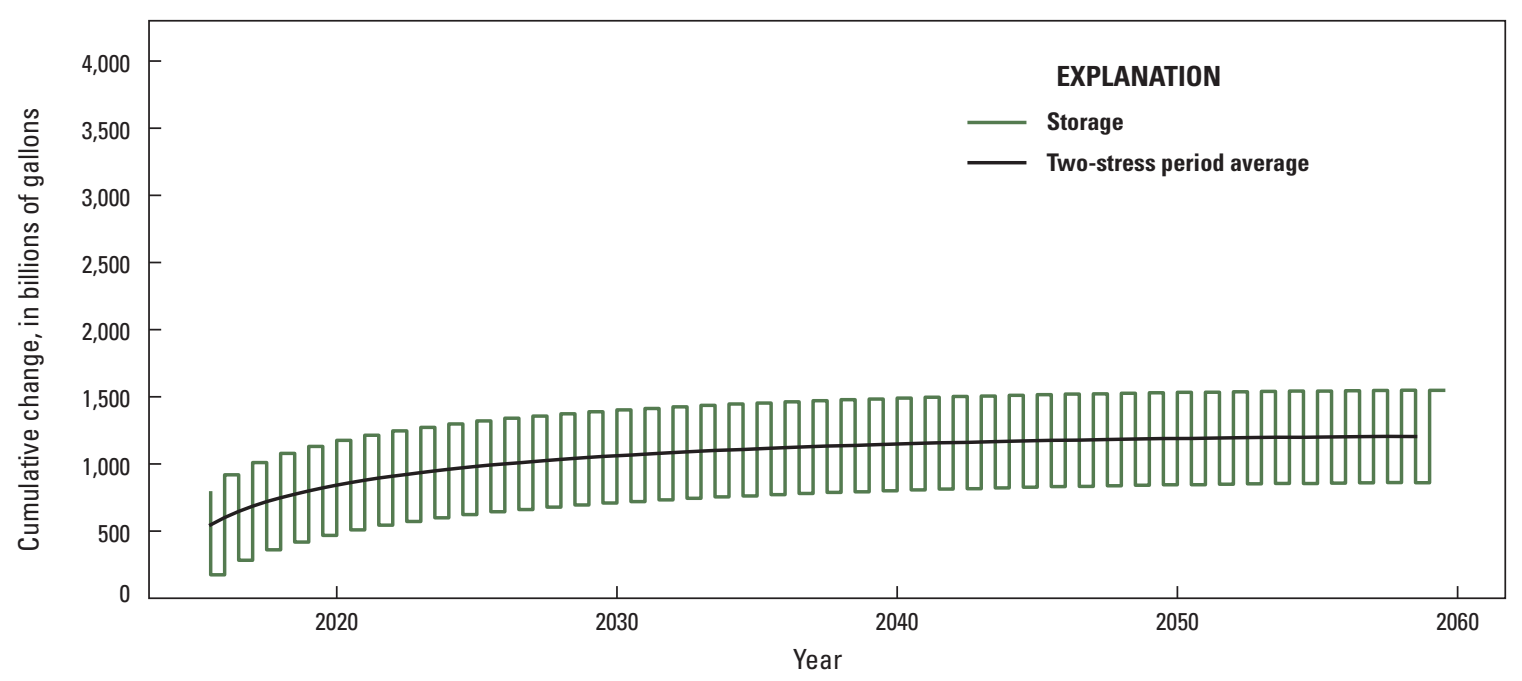

B. Ozark aquifer

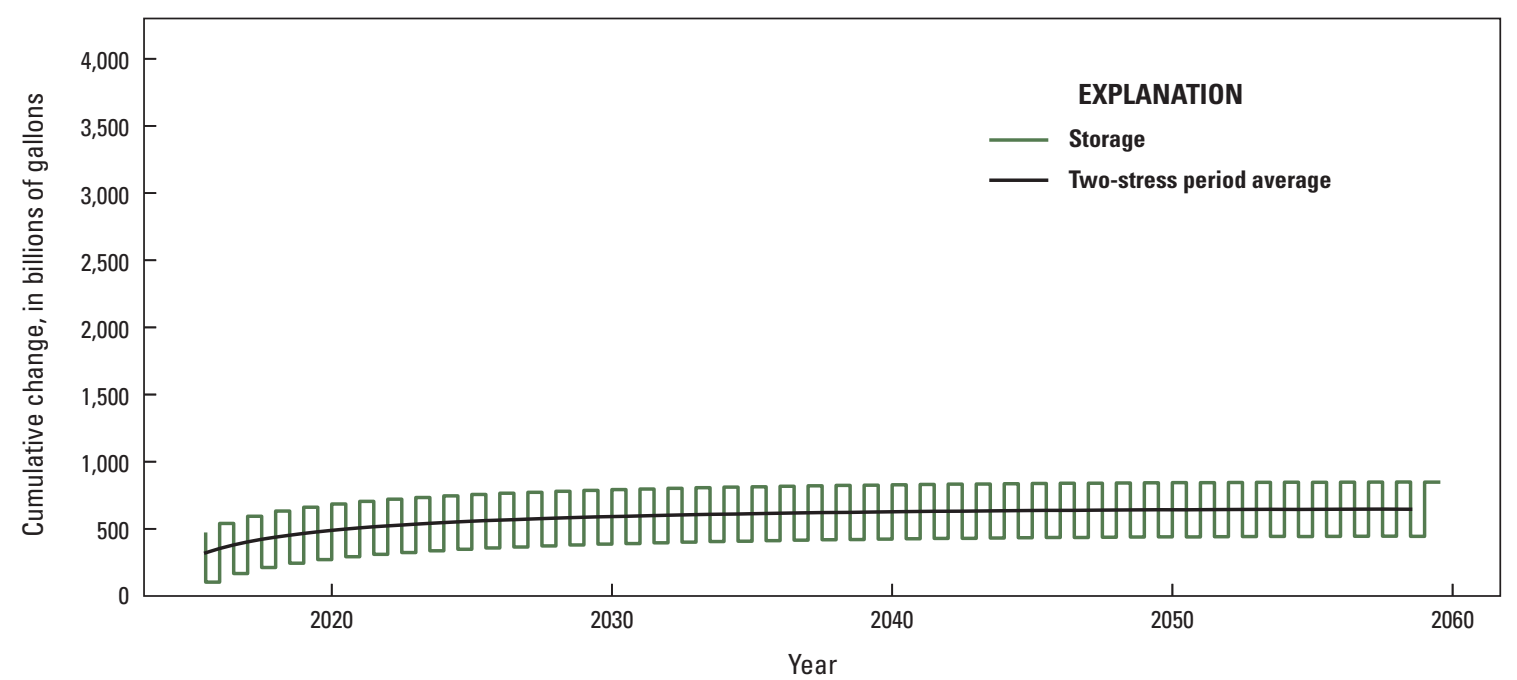

Figure 19. Storage change from 2015 to 2060 for the baseline scenario for the $A$, Ozark Plateaus aquifer system and $B$, Ozark aquifer. 
A. Ozark Plateaus aquifer system

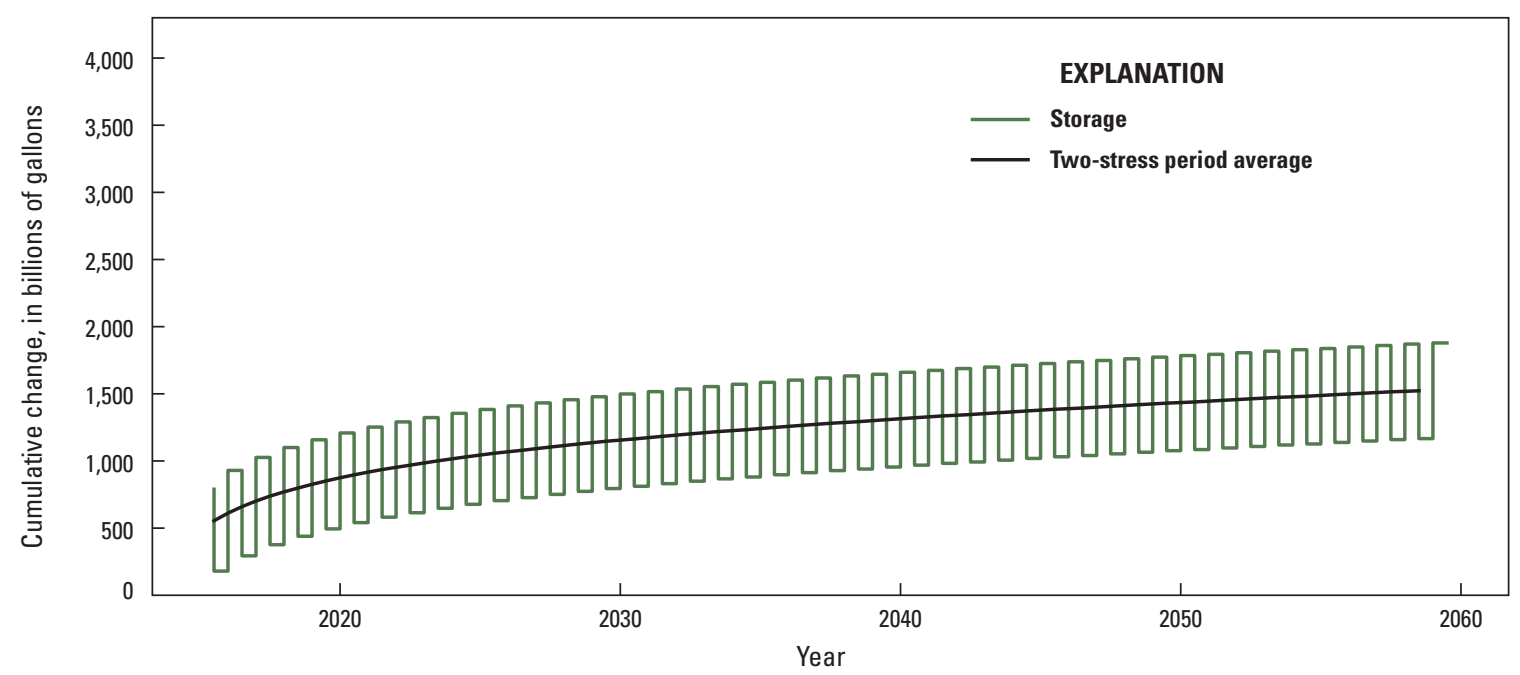

B. Ozark aquifer

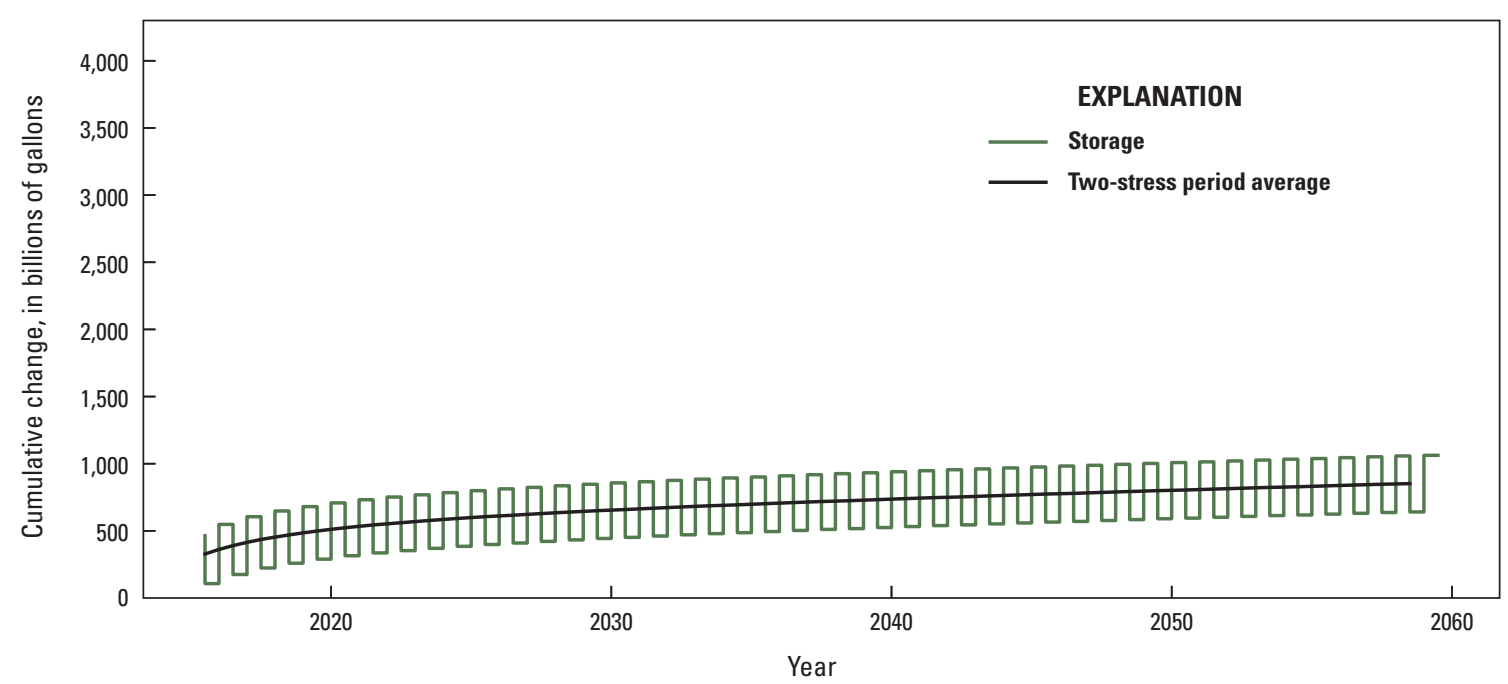

Figure 20. Storage change from 2015 to 2060 for the pumping scenario for the $A$, Ozark Plateaus aquifer system and $B$, Ozark aquifer. 
A. Ozark Plateaus aquifer system

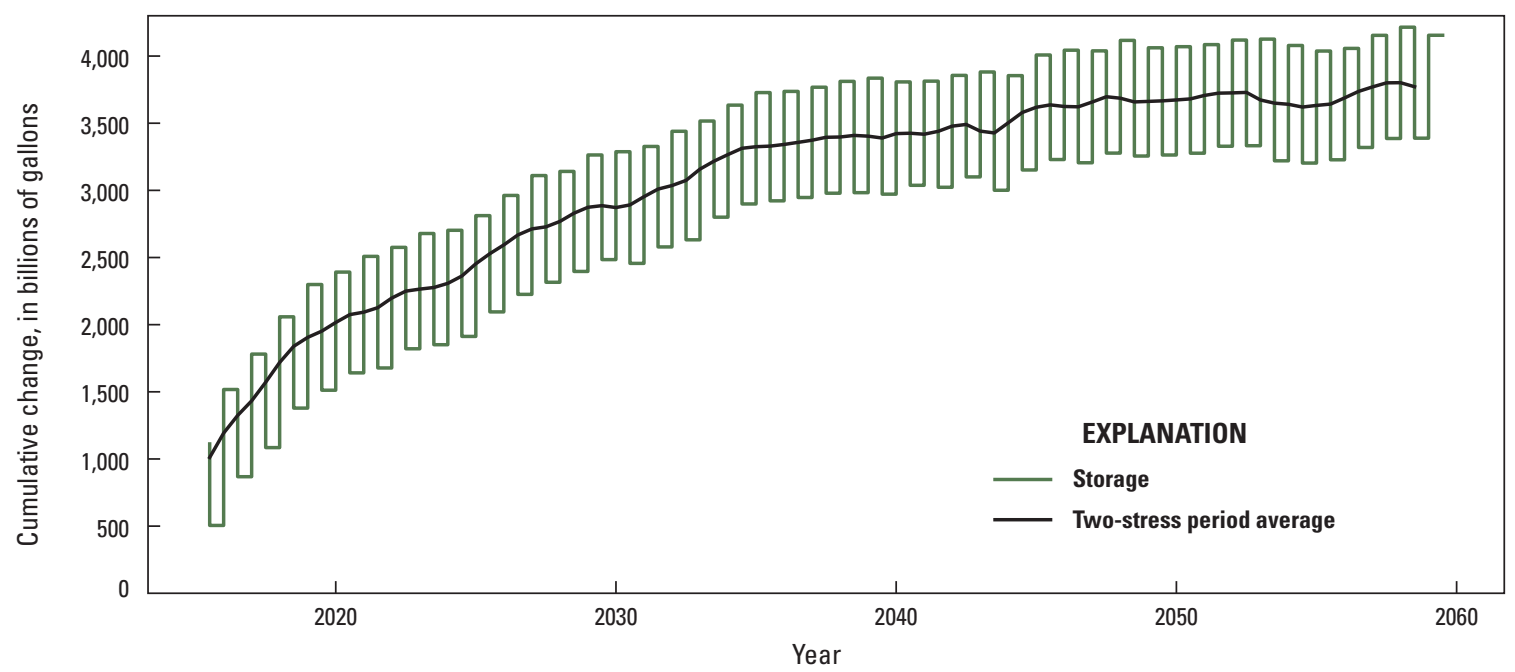

\section{B. Ozark aquifer}

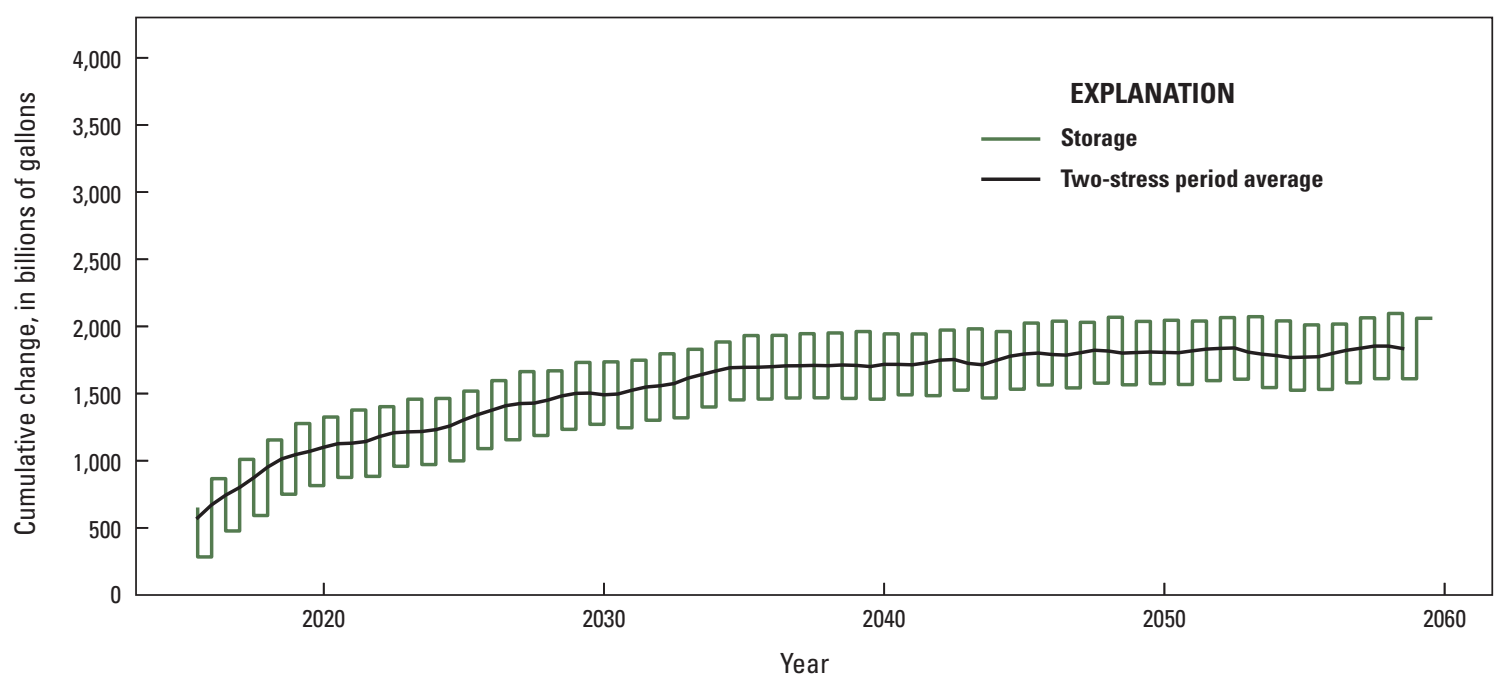

Figure 21. Storage change from 2015 to 2060 for the general circulation model scenario for the $A$, Ozark Plateaus aquifer system and $B$, Ozark aquifer. 


\section{Simulation Uncertainty}

A numerical groundwater model may be adequately history matched according to traditional calibration measures, such as when the best-fit parameters yield an acceptable fit with the observation dataset and are in general agreement with aquifer-specific expert knowledge. However, many parameter values have a wide range in uncertainty even after history matching. If the forecasts (or predictions) of interest are sensitive to these uncertain parameter values, then substantial uncertainty about these forecasts may also remain following history matching. Therefore, linear uncertainty analysis was used to quantify parameter and predictive uncertainty when using the scenarios simulating future potential conditions. (See appendix 2 for an explanation and the computational details of linear uncertainty analysis.)

\section{Parameter Uncertainty}

In general, the reduction in uncertainty tends to increase for parameters in areas with numerous observations and stressed areas of the model. Reductions in the uncertainty of parameters related to aquifer properties were highly variable, ranging from no reduction in uncertainty to almost 98 percent (table 3). The history matching effort was helpful in informing many of the parameters that influence stream discharge to and from groundwater, specifically the streambed conductance multipliers for 8-digit hydrologic unit codes (table 3). The horizontal flow boundary multiplier and the constant head boundary parameters in the Western Interior Plains confining system and the lower Ozark aquifer were well informed by the observation dataset, whereas the constant head boundary parameter in the St. Francois aquifer was not (table 3). Parameters related to boundary conditions and aquifer properties are valuable in evaluating the conceptualization of the flow system. Collecting more information about parameters and collecting more observation information could potentially reduce the uncertainty of parameters, advance model development, and aid calibration exercises.

Spatial and temporal recharge multiplier parameter uncertainties are important for understanding how reliably recharge is estimated and implemented in the model. The same is true for the temporal well multiplier parameter uncertainty and pumping in the model. The linear uncertainty analysis indicated that history matching did not decrease the uncertainties of the different recharge and well parameters (table 3). Recharge from rainfall and local-scale water withdrawals from wells are the driving forces behind groundwater flow and heads in the Ozark Plateaus aquifer system. Increased knowledge of recharge processes and water withdrawals from the aquifer system could potentially decrease the uncertainty of these parameters, thereby benefiting model developments.

\section{Prediction Uncertainty}

Model parameters retain uncertainty even after they have been subjected to the history-matching process, and can therefore continue to affect predictions of interest. To more clearly distinguish the reliability of model predictions, it is necessary to evaluate uncertainty in predictions made by groundwater models based on best-fit parameters with explicit consideration of parameter uncertainty. (See appendix 2 for an explanation and the computational details of predictive linear uncertainty analysis.)

Head forecasts, representing the heads located at 94 real-time observation wells, were used as quantitative targets for the three predictive models (as described by the aforementioned three scenarios) and associated uncertainty analyses. Predictive uncertainty results from the baseline and GCM scenarios indicate that the prior uncertainty of model input parameters produced margins of error in excess of $100 \mathrm{ft}$ for about half of the head predictions (figs. 22 and $23)$; under the pumping scenario, the prior uncertainty of model input parameters produced margins of error in excess of $100 \mathrm{ft}$ for more than half of the head predictions (fig. 24). The history-matching process provided important information to inform prediction-sensitive model parameters. After the history-matching effort, more than half of the head forecasts in the pumping scenario had margins of error less than $25 \mathrm{ft}$ (fig. 24). For the baseline scenario, the history-matching process resulted in 73 percent of the head forecasts having margins of error less than $25 \mathrm{ft}$ (fig. 22). Results of the history-matching effort for the GCM scenario were similar to those of the baseline scenario (fig. 23). The reduction in uncertainty with respect to the head forecasts located at the 94 real-time observation wells implies that the observation dataset is informing those adjustable parameters that control these predictions and that these predictions can be made with some reliability.

Out of the 94 locations serving as positions for waterlevel predictions, 93 were also part of the observation dataset used in the history-matching effort. Reduction in predictive uncertainty is likely to be larger for predictions that are similar, either in location or type, to observations in the dataset employed in the history-matching process, especially if observations at prediction locations contain significant information pertaining to prediction-sensitive adjustable parameters. It is also important to note that the head forecasts at the 94 forecast locations were absolute predictions. Absolute values are more difficult to accurately predict than a difference, such as the difference in head from the start of the model simulation to the end of the model simulation. 
Table 3. Percent reduction in uncertainty associated with groups of adjustable model parameters.

[* only one parameter in the group]

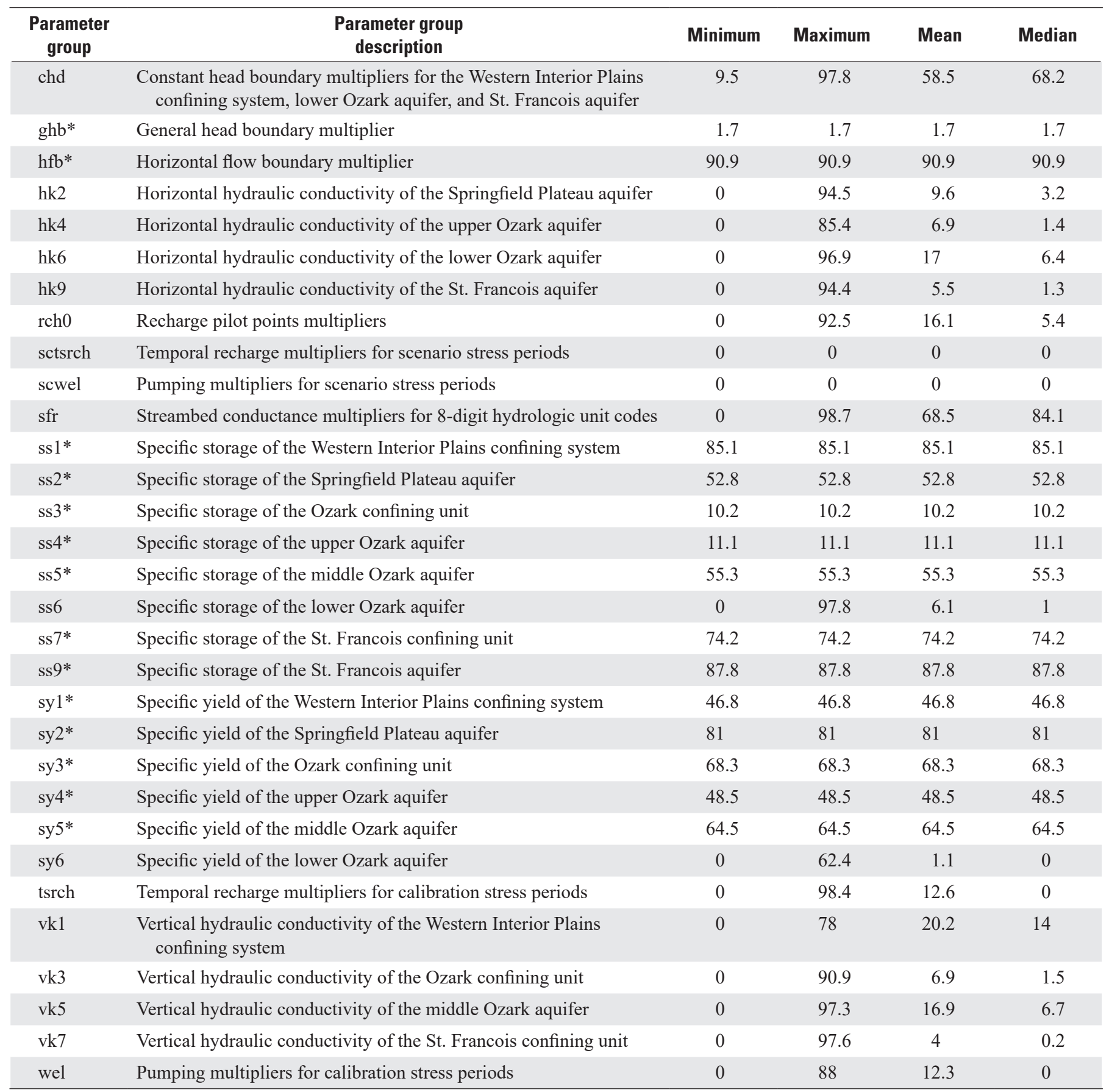




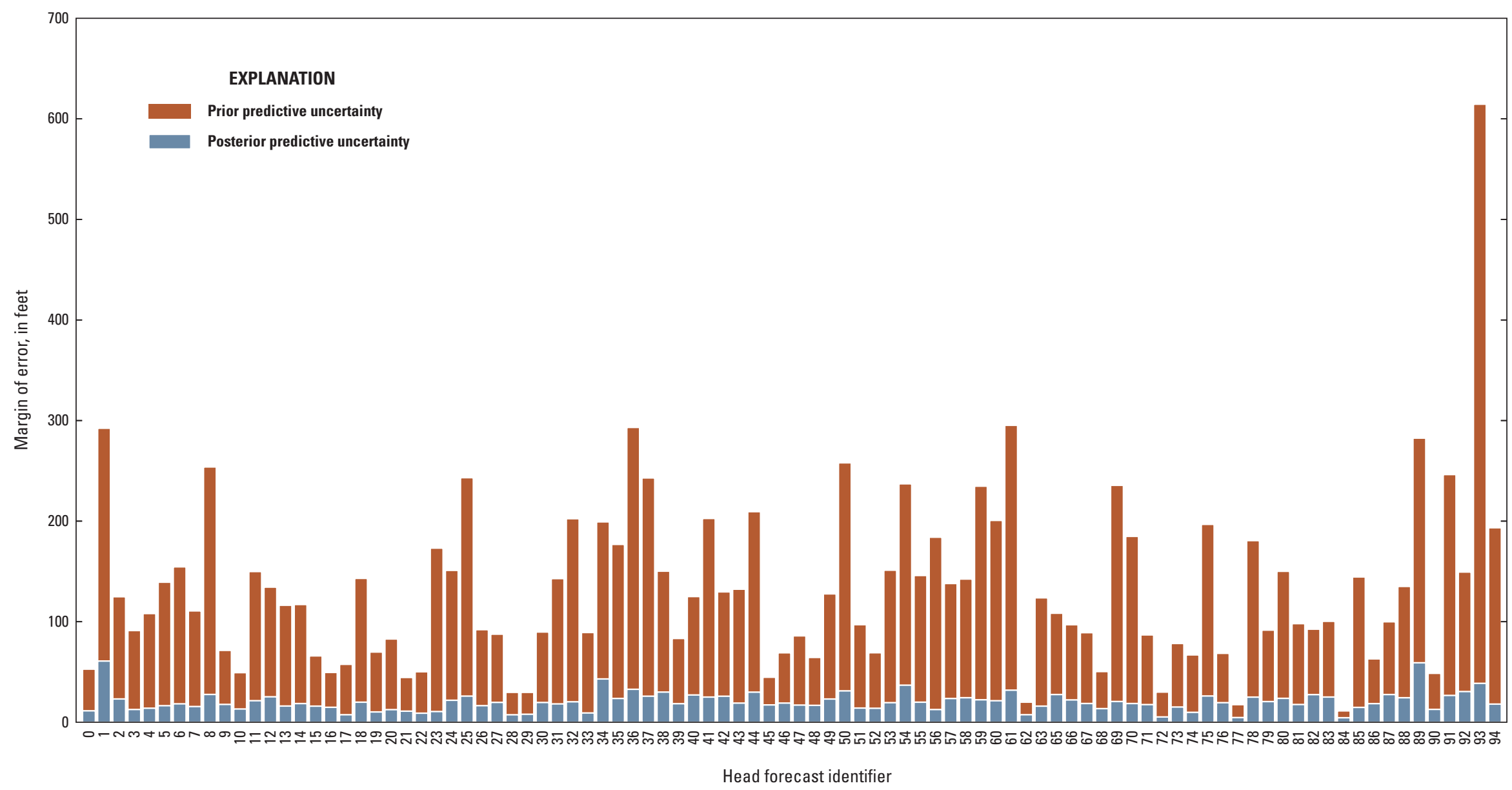

Figure 22. The margin of error, or radius, of the 95-percent credible interval for the prior and posterior predictive uncertainty of head during the 2016-60 model period for the baseline scenario at real-time observation wells of interest in the Ozark Plateaus aquifer system. Head forecast identifiers are arbitrary numbers assigned to each head prediction for the purpose of differentiation. See table 2.1 for head forecast identifier and associated model layer. 


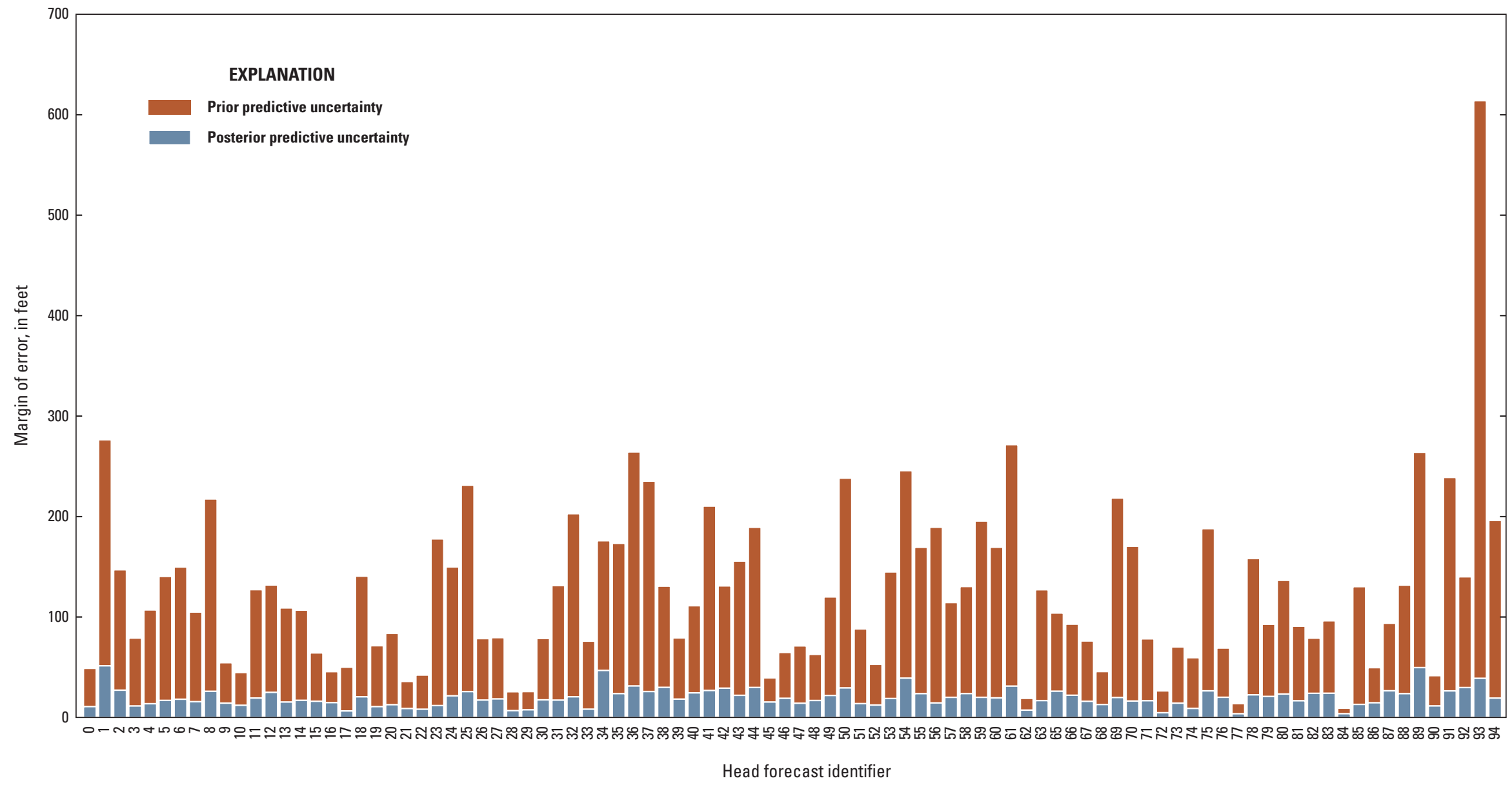

Figure 23. The margin of error, or radius, of the 95-percent credible interval for the prior and posterior predictive uncertainty of head during the 2016-60 model period for the general circulation model scenario at real-time observation wells of interest in the Ozark Plateaus aquifer system. Head forecast identifiers are arbitrary numbers assigned to each head prediction for the purpose of differentiation. See table 2.1 for head forecast identifier and associated model layer. 


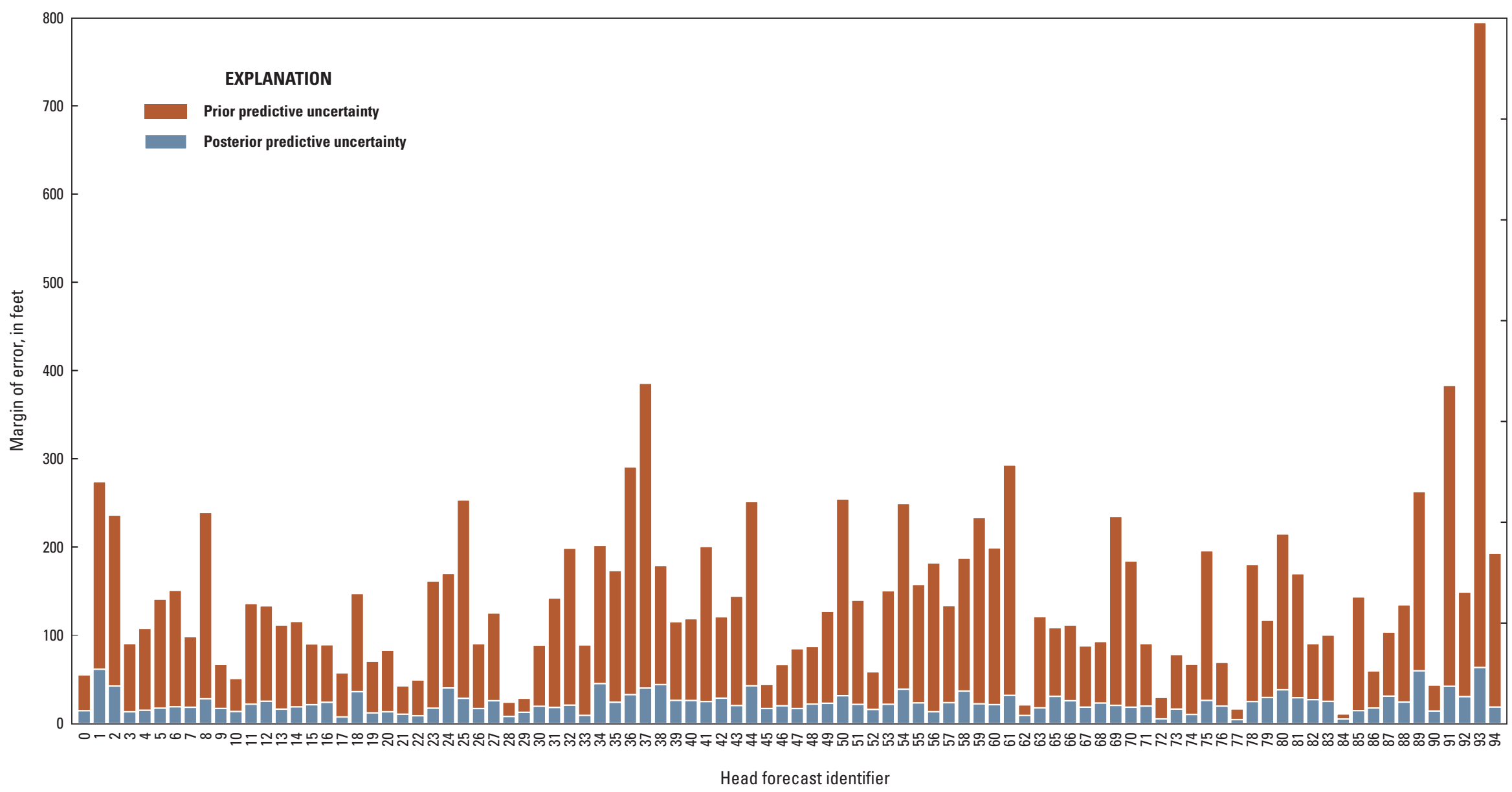

Figure 24. The margin of error, or radius, of the 95-percent credible interval for the prior and posterior predictive uncertainty of head during the 2016-60 model period for the pumping scenario at real-time observation wells of interest in the Ozark Plateaus aquifer system. Head forecast identifiers are arbitrary numbers assigned to each head prediction for the purpose of differentiation. See table 2.1 for head forecast identifier and associated model layer. 


\section{Data-Worth Analysis-Use of Numerical Models to Inform Groundwater Networks}

Data worth can be divided into two main categories: (1) the worth of data pertaining directly to parameters, and (2) the worth of data pertaining indirectly to observations. Reducing the uncertainty of parameters in a model typically reduces the uncertainty of predictions of interest. Parameter uncertainty can be reduced either directly by collecting more or better information about parameters, or indirectly by collecting more or better information about observations that inform adjustable parameters estimated through the history-matching process. Thus, linear-based uncertainty analyses (White and others, 2016) were used to quantitatively evaluate which parameters or groups of parameters are contributing most to the prior and posterior uncertainty associated with the 94 head predictions. (See appendix 2 for further explanation of the linear uncertainty analysis used to evaluate the worth of data pertaining to parameters.)

Multiple groundwater-level monitoring networks exist in the Ozark system. In northern Arkansas, 50 to 60 wells in the Ozark system are measured on an approximate 3-year rotation (Czarnecki and others, 2014; Schrader, 2015). In Missouri, about 90 wells in the Ozark system are included in a realtime network (Missouri Department of Natural Resources, 2018). These wells and more were used to create a regional potentiometric map of the Ozark system in the winter of 2014-15 (Nottmeier, 2015). Many of the water levels used to construct the potentiometric surface representing the winter of 2014 conditions also were used as observations for calibration purposes in the model. The Ozark model was used to evaluate the worth of existing observations; for example, a subset of the real-time well locations was used as predictions within the scenarios presented in the report section "Evaluation of Potential Future Conditions."

\section{The Worth of Data Pertaining Directly to Parameters}

Linear-based uncertainty analysis was used to evaluate the parameter groups contributing most to the uncertainty for each of the 94 head forecasts. The parameter groups comprising riverbed conductance multipliers, vertical hydraulic conductivities for the middle Ozark aquifer and the Ozark confining unit, and horizontal hydraulic conductivities for the Springfield Plateau, lower Ozark, and St. Francois aquifers were common to all three scenarios and had the most influence on the head measurements at the evaluated locations. Because 87 percent of the head forecasts are located in the lower Ozark aquifer and 7 percent are located in the Springfield Plateau aquifer, this influence on the head measurements is expected. For all three scenarios, the horizontal hydraulic conductivity for the lower Ozark aquifer was the most important parameter group for 20 percent of the head predictions of interest, contributing, on average, 40 percent to the predictive uncertainty at these head forecasts. Similarly, the vertical hydraulic conductivity parameter for the middle Ozark aquifer contributed most to predictive uncertainty at 13 percent of head forecasts, accounting for about 40 percent of the predictive uncertainty at these head forecasts. The riverbed conductance parameter played a larger role in predictive uncertainty, contributing approximately 60 percent, but at a smaller number of the head forecasts of interest ( 5 percent).

For all three scenarios, future recharge played an important role in determining the uncertainty at more than half of the 94 head forecasts. The temporal recharge multiplier contributed about 55 percent to the predictive uncertainty in head forecasts. If future groundwater-flow model forcings, such as recharge, are sufficiently uncertain, it may be more beneficial for model development to focus on understanding the effects of these future forcings rather than on traditional history-matching exercises designed to adjust temporally static model parameters, such as aquifer properties (Anderson and others, 2015; White and others, 2016). Independent measurement of sensitive parameters should reduce uncertainty in parameter values and therefore should improve predictions of groundwater levels in the future. The parameters with the highest value for future work are parameters that control recharge rates, the connectivity of rivers and streams to groundwater, lateral flow through the lower Ozark aquifer, and vertical flow through the middle Ozark aquifer.

\section{The Worth of Data Pertaining Indirectly to Observations}

Linear-based uncertainty analysis was also used to identify the most valuable head observations for predicting water levels at all forecast locations. For all three scenarios, the water level observations associated with forecast locations 2 and 3 were the two most important observation groups for reducing posterior uncertainty at all predictions of interest (figs. 15-17). These observations are informing the parameters to which the head forecasts are sensitive during the history-matching process and are important for reducing the margins of error for the 94 head forecasts. Conversely, the observations associated with forecast locations 93,84 , and 74 play a comparatively miniscule role in reducing predictive uncertainty for all three scenarios (figs. 15-17). Based on this example of data worth, these observations could be considered redundant in informing the existing groundwater monitoring network and may be targets for removal.

It should be noted that an analysis of data worth can also be applied to any potential, model relevant observations, such as proposed monitoring wells or stream leakage measurements. The above data worth analysis provides an example involving existing monitoring locations. A more rigorous evaluation of data worth across the Ozark model might include a uniform grid of potential observation locations or select stream reaches. 


\section{Challenges for Future Groundwater Availability Assessments-Lessons Learned}

This groundwater assessment of the Ozark system provides the first transient model of regional groundwater flow encompassing the freshwater resources of the area. The information and knowledge of the system incorporated into this report was supported by previous investigations at regional and local scales. The regional assessments provided by Imes and Emmett (1994) provided the foundation upon which model v1.1 was developed. Nationwide, 12 regional groundwater availability assessments have been completed as of 2018 and 11 are in progress; these assessments include many of the Nation's primary aquifers. These regional assessments represent a large investment in time and resources to compile, interpret, and publish results. As with the previous work from the Regional Aquifer System Assessment (RASA), one of the great challenges is archiving this wealth of information in a way that is accessible in the future, and that can be easily used as the foundation for studies at higher spatial and temporal resolutions. Other regional studies conducted by the USGS have noted additional challenges related to error or uncertainty in the various inputs on which the simulations are built-recharge, pumping, evapotranspiration, stream interaction, observation information, aquifer properties, and model discretization are often mentioned. This study is no different, as many of these inputs contain some amount of spatial and temporal uncertainty. Therefore, the challenge of providing accessible data is extended in that the data should be accompanied by some measure of uncertainty. As studies evolve, some in the same areas as past simulations, the data should be improved, and the uncertainty reduced with versions of the information stored and accessed for future work. In this way, each pathway of information can be better adjusted for more accurate historical and spatial representation in groundwater-flow models for various scales. The building and use of accessible, evolving information may be one of the greater challenges facing future groundwater availability assessments.

\section{Acknowledgments}

The Ozark Plateaus aquifer study was conducted with support from the U.S. Geological Survey Water Availability and Use Science Program, formerly the Groundwater Resources Program. The authors wish to thank the many talented individuals who have contributed to this Professional Paper. Suggestions by U.S. Geological Survey personnel Kevin Dennehy (retired), John Masterson, Erick Burns, Mike Fienen, and Randy Hunt were valuable through the modeling and report process.

\section{References Cited}

Adamski, J.C., Petersen, J.C., Freiwald, D.A., and Davis, J.V., 1995, Environmental and hydrologic setting of the Ozark Plateaus study unit, Arkansas, Kansas, Missouri, and Oklahoma: U.S. Geological Survey Water-Resources Investigations Report 94-4022, 76 p., accessed March 25, 2019, at https://pubs.usgs.gov/wri/wri944022/WRIR944022.pdf.

Alder, J.R., and Hostetler, S.W., 2013, USGS National Climate Change Viewer: U.S. Geological Survey, accessed March 25, 2019, at https://www2.usgs.gov/climate_landuse/clu_rd/ nccv.asp.

Anderson, M.P., Woessner, W.W., and Hunt, R.J., 2015, Applied groundwater modeling simulation of flow and advective transport (2d ed.): London, United Kingdom, Academic Press-Elsevier, 564 p.

Brahana, J.V., Tennyson, R., Terry, J., Hays, P.D., and Pollock, E.D., 2009, Reactivated basement faulting as a hydrogeologic control of hypogene speleogenesis in the southern Ozarks of Arkansas, USA, in Stafford, K.W., Land, L., and Veni, G., eds., Advances in hypogene studies: National Cave and Karst Research Institute Symposium 1-National Cave and Karst Research Institute, p.99-110, accessed March 25, 2019 at https://digital. lib.usf.edu/content/SF/S0/05/26/82/00001/K26-02233Symposium_0609_full.pdf.

Christenson, S.C., Parkhurst, D.L., and Fairchild, R.W., 1990, Geohydrology and water quality of the Roubidoux aquifer, northeastern Oklahoma: U.S. Geological Survey Open-File Report 90-570, 116 p., accessed May 1, 2018, at https:// pubs.usgs.gov/of/1990/0570/report.pdf.

Clark, B.R., Richards, J.M., and Knierim, K.J., 2018, The Ozark Plateaus Regional Aquifer Study_-Documentation of a groundwater-flow model constructed to assess water availability in the Ozark Plateaus: U.S. Geological Survey Scientific Investigations Report 2018-5035, 33 p., accessed February 16, 2019, at https://doi.org/10.3133/sir20185035.

Clark, B.R., Westerman, D.A., and Fuggitt, D.T., 2013, Enhancements to the Mississippi Embayment Regional Aquifer Study (MERAS) groundwater-flow model and simulations of sustainable water-level scenarios: U.S. Geological Survey Scientific Investigations Report 2013-5161, 29 p., accessed March 25, 2019, at https://pubs. usgs.gov/sir/2013/5161/.

Czarnecki, J.B., Gillip, J.A., Jones, P.M., and Yeatts, D.S., 2009, Groundwater-flow model of the Ozark Plateaus aquifer system, northwestern Arkansas, southeastern Kansas, southwestern Missouri, and northeastern Oklahoma: U.S. Geological Survey Scientific Investigations Report 2009-5148, 62 p. (Revised March 2010). 
Czarnecki, J.B., Pugh, A.L., and Blackstock, J.M., 2014, Potentiometric surface of the Ozark aquifer in northern Arkansas, 2010: U.S. Geological Survey Scientific Investigations Report 2014-5013, 16 p., 1 pl., accessed February 16, 2019, at http://dx.doi.org/10.3133/ sir20145013.

Doherty, J., 2016, PEST, Model-independent parameter estimation-User manual (6th ed.): Brisbane, Australia, Watermark Numerical Computing, 390 p., accessed June 18, 2018, at http://www.pesthomepage.org/Downloads.php.

Doherty, J.E., Hunt, R.J., and Tonkin, M.J., 2010, Approaches to highly parameterized inversion - A guide to using PEST for model-parameter and predictive-uncertainty analysis: U.S. Geological Survey Scientific Investigations Report 2010-5211, 71 p.

Duncan, L.L., and Clark, B.R., 2018, MODFLOW-NWT model of groundwater flow in the Ozark Plateaus aquifer system: U.S. Geological Survey data release, https://doi. org/10.5066/F718350W.

Duncan, L.L., and Clark, B.R., 2019, MODFLOW-NWT model of groundwater flow in the Ozark Plateaus aquifer system, version 1.1: U.S. Geological Survey data release, https://doi.org/10.5066/P9H0PQ93.

Fienen, M.N., Doherty, J.E., Hunt, R.J., and Reeves, H.W., 2010, Using prediction uncertainty analysis to design hydrologic monitoring networks-Example applications from the Great Lakes Water Availability Pilot project: U.S. Geological Survey Scientific Investigations Report 2010-5159, 44 p.

Harbaugh, A.W., 2005, MODFLOW-2005, the U.S. Geological Survey modular ground-water flow modelThe ground-water flow process: U.S. Geological Survey Techniques and Methods book 6, chap. A16, variously paged.

Harvey, E.J., Skelton, J., and Miller, D.E., 1983, Hydrology of carbonate terrane-Niangua, Osage Fork, and Grandglaize Basins, Missouri: Rolla, Mo., Missouri Division of Geology and Land Survey Water Resources Report 35, 132 p., accessed March 25, 2019 at https://dnr. mo.gov/pubs/WR35.pdf.

Hays, P.D., Knierim, K.J., Breaker, B.K., Westerman, D.A., and Clark, B.R., 2016, Hydrogeology and hydrologic conditions of the Ozark Plateaus aquifer system: U.S. Geological Survey Scientific Investigations Report 2016-5137, 73 p., accessed November 28, 2016, at https:// pubs.er.usgs.gov/publication/sir20165137.
Hostetler, S.W., and Alder, J.R., 2016, Implementation and evaluation of a monthly water balance model over the US on an 800 m grid: Water Resources Research, v. 52, no. 12, accessed February 16, 2019, at https://doi. org/10.1002/2016WR018665.

Howe, W.B., and Koenig, J.W., 1961, The stratigraphic succession in Missouri: Missouri Division of Geology and Land Survey, v. 40, 185 p.

Hudson, M.R., 2000, Coordinated strike-slip and normal faulting in the southern Ozark dome of northern ArkansasDeformation in a late Paleozoic foreland: Geology, v. 28, no. 6, p. 511-514.

Imes, J.L., and Emmett, L.F., 1994, Geohydrology of the Ozark Plateaus aquifer system in parts of Missouri, Arkansas, Oklahoma, and Kansas: U.S. Geological Survey Professional Paper 1414-D, 140 p., accessed June 20, 2014, at https://pubs.er.usgs.gov/publication/pp1414D.

Intergovernmental Panel on Climate Change, 2014, Climate Change 2014: Synthesis Report. Contribution of Working Groups I, II and III to the Fifth Assessment Report of the Intergovernmental Panel on Climate Change [Core Writing Team, R.K. Pachauri and L.A. Meyer (eds.)]. Geneva, Switzerland, Intergovernmental Panel on Climate Change, $151 \mathrm{p}$.

Jorgensen, D.G., Helgesen, J.O., and Imes, J.L., 1993, Regional aquifers in Kansas, Nebraska, and parts of Arkansas, Colorado, Missouri, New Mexico, Oklahoma, South Dakota, Texas, and Wyoming; geohydrologic framework: U.S. Geological Survey Professional Paper 1414-B, accessed March 25, 2019, at https://pubs.er.usgs. gov/publication/pp1414B.

Jorgensen, D.G., Helgesen, J.O., Signor, D.C., Leonard, R.B., Imes, J.L., and Christensen, S.C., 1996, Analysis of regional aquifers in the central Midwest of the United States in Kansas, Nebraska, and parts of Arkansas, Colorado, Missouri, New Mexico, Oklahoma, South Dakota, Texas, and Wyoming - Summary: U.S. Geological Survey Professional Paper 1414-A, accessed March 25, 2019, at https://pubs.er.usgs.gov/publication/pp1414A.

Knierim, K.J., Nottmeier, A.M., Worland, S., Westerman, D.A., and Clark, B.R., 2016, Groundwater withdrawal rates from the Ozark Plateaus aquifer system, 1900 to 2010: U.S. Geological Survey data release, accessed February 16, 2019, at https://dx.doi.org/10.5066/F7GQ6VV1.

Knierim, K.J., Nottmeier, A.M., Worland, S., Westerman, D.A., and Clark, B.R., 2017, Challenges for creating a site-specific groundwater-use record for the Ozark Plateaus aquifer system (central USA) from 1900 to 2010: Hydrogeology Journal, v. 25, no. 6, p. 1779-1793, accessed February 16, 2019, at https://doi.org/10.1007/s10040-0171593-1. 
Knierim, K.J., Wagner, D.M., Roland, V.L., and Nottmeier, A.M., 2015, Ozark Plateaus seepage run dataset, southern Missouri and northern Arkansas, 1982-2006: U.S. Geological Survey data release, accessed September 14, 2015, at http://dx.doi.org/10.5066/F7W9577Q.

Kresse, T.M., Hays, P.D., Merriman-Hoehne, K.R., Gillip, J.A., Fuggitt, D.T., Spellman, J.L., Nottmeier, A.M., Westerman, D.A., Blackstock, J.M., and Battreal, J.L., 2014, Aquifers of Arkansas-Protection, management, and hydrologic and geochemical characteristics of groundwater resources in Arkansas: U.S. Geological Survey Scientific Investigations Report 2014-5149, 360 p., accessed March 25, 2019, at https://pubs.usgs.gov/sir/2014/5149/pdf/ sir2014-5149.pdf.

Macfarlane, P.A., Healey, J.M., and Wilson, B.B., 2005, The southeast Kansas Ozark aquifer water supply program: Kansas Geological Survey Open File Report 2005-15, 52 p.

Mesko, T.O., and Imes, J.L., 1995, Discharge of ground water along the Ozark Escarpment in southeastern Missouri and northeastern Arkansas: U.S. Geological Survey 95-4103, 15 p., accessed August 15, 2014, at http://pubs.usgs.gov/ wri/1995/4103/report.pdf.

Meyer, C.D., 2000, Matrix analysis and applied linear algebra: Philadelphia, Pennsylvania, Society for Industrial and Applied Mathematics, $718 \mathrm{p}$.

Miller, D.E., and Vandike, J.E., 1997, Groundwater resources of Missouri: Missouri Department of Natural Resources, Division of Geology and Land Survey, Water Resources Report 46, 277 p., accessed March 25, 2019, at https://dnr. mo.gov/pubs/WR46.pdf.

Miller, J.A., and Appel, C.I., 1997, Ground water atlas of the United States-Segment 3, Kansas, Missouri, Nebraska: U.S. Geological Survey Hydrologic Investigations Atlas HA-730-D, 24 p., accessed June 20, 2014, at https://doi. org/10.3133/ha730D.

Missouri Department of Natural Resources, 2018, Groundwater-level observation well network, accessed March 22, 2018, at https://dnr.mo.gov/geology/wrc/ groundwater/gwnetwork.htm?/env/wrc/groundwater/ gwnetwork.htm.

Niswonger, R.G., Panday, S., and Ibaraki, M., 2011, MODFLOW-NWT, A Newton formulation for MODFLOW-2005: U.S. Geological Survey Techniques and Methods 6-A37, accessed April 19, 2016, at https://pubs. er.usgs.gov/publication/tm6A37.
Nottmeier, A.M., 2015, Regional potentiometric surface of the Ozark aquifer in Arkansas, Kansas, Missouri, and Oklahoma, November 2014-January 2015: U.S. Geological Survey Scientific Investigations Map 3348, 1 sheet, accessed February 16, 2019, at http://dx.doi.org/10.3133/ $\operatorname{sim} 3348$.

Reed, T.B., and Burnett, R.D., 1985, Compilation and analysis of aquifer performance tests in eastern Kansas: U.S. Geological Survey Open-File Report 85-200, 129 p.

Reilly, T.E., Dennehy, K.F., Alley, W.M., and Cunningham, W.L., 2008, Ground-water availability in the United States: U.S. Geological Survey Circular 1323, 70 p. [Also available at https://pubs.usgs.gov/circ/1323/.]

Reitz, M.D., Sanford, W.E., Senay, G.B., and Cazenas, J., 2015, Annual regression-based estimates of evapotranspiration for the contiguous United States based on climate, remote sensing, and stream gage data: American Geophysical Union, proceedings, accessed January 30, 2017, at https://agu.confex.com/agu/fm15/webprogram/ Paper84061.html.

Reitz, M., Sanford, W.E., Senay, G.B., and Cazenas, J., 2017, Annual estimates of recharge, quick-flow runoff, and evapotranspiration for the contiguous U.S. using empirical regression equations: Journal of the American Water Resources Association, v. 53, no. 4, p. 961-983.

Richards, J.M., 2010, Groundwater-flow model and effects of projected groundwater use in the Ozark Plateaus Aquifer System in the vicinity of Greene County, Missouri-1907-2030: U.S. Geological Survey Scientific Investigations Report 2010-5227, 106 p.

Richards, J.M., and Mugel, D.N., 2008, Potentiometric Surface of the Ozark Aquifer near Springfield, Missouri, 2006-07: U.S. Geological Survey Scientific Investigations Map 3003, accessed March 25, 2019, at https://pubs.er.usgs. gov/publication/sim3003.

Schrader, T.P., 2015, Water levels of the Ozark aquifer in northern Arkansas, 2013: U.S. Geological Survey Scientific Investigations Report 2015-5088, 17 p., 1 pl., accessed February 16, 2019, at http://dx.doi.org/10.3133/ $\operatorname{sir} 20155088$.

Seager, R., Feldman, J., Lis, N., Ting, M., Williams, A.P., Nakamura, J., Liu, H., and Henderson, N., 2017, Whither the 100th meridian? The once and future physical and human geography of America's arid-humid divide. Part II: The meridian moves east: Earth Interactions, v. 22, no. 5, p. 1-24. 
Stoeser, D.B., Green, G.N., Morath, L.C., Heran, W.D., Wilson, A.B., Moore, D.W., and Van Gosen, B.S., 2005, Preliminary integrated geologic map databases for the United States-Central States-Montana, Colorado, New Mexico, North Dakota, South Dakota, Nebraska, Kansas, Oklahoma, Texas, Iowa, Missouri, Arkansas, and Louisiana (version 1.2, December 2007): U.S. Geological Survey Open-File Report 2005-1351, accessed December 29, 2017, at https://pubs.usgs.gov/of/2005/1351/.

Thrasher, B., Xiong, J., Wang, W., Melton, F., Michaelis, A., and Nemani, R., 2013, Downscaled climate projections suitable for resource management: Eos, v. 94, no. 37, p. 321-323, accessed February 16, 2019, at https://doi. org/10.1002/2013EO370002.

Welter, D.E., White, J.T., Hunt, R.J., and Doherty, J.E., 2015, Approaches in highly parameterized inversion-PEST++ Version 3, a Parameter ESTimation and uncertainty analysis software suite optimized for large environmental models: U.S. Geological Survey Techniques and Methods, book 7, chap. C12, 54 p., accessed January 16, 2018, at http:// dx.doi.org/10.3133/tm7C12.

Westenbroek, S.M., Kelson, V.A., Dripps, W.R., Hunt, R.J., and Bradbury, K.R., 2010, SWB-A modified Thornthwaite-Mather Soil-Water-Balance code for estimating groundwater recharge: U.S. Geological Survey Techniques and Methods 6-A31, accessed August 7, 2015, at https://pubs.er.usgs.gov/publication/tm6A31.

Westerman, D.A., Gillip, J.A., Richards, J.M., Hays, P.D., and Clark, B.R., 2016a, Altitudes and thicknesses of hydrogeologic units of the Ozark Plateaus aquifer system in Arkansas, Kansas, Missouri, and Oklahoma: U.S. Geological Survey data release, accessed February 16, 2019, at http://dx.doi.org/10.5066/F7HQ3X0T.

Westerman, D.A., Gillip, J.A., Richards, J.M., Hays, P.D., and Clark, B.R., 2016b, Altitudes and thicknesses of hydrogeologic units of the Ozark Plateaus aquifer system in Arkansas, Kansas, Missouri, and Oklahoma: U.S. Geological Survey Scientific Investigations Report 2016$5130,32 \mathrm{p}$.

White, J.T., Fienen, M.N., and Doherty, J.E., 2016, A python framework for environmental model uncertainty analysis: Environmental Modelling \& Software, v. 85, p. 217-228, accessed February 16, 2019, at http://dx.doi.org/10.1016/j. envsoft.2016.08.017.

White, J.T., Welter, D.E., Hunt, R.J., and Doherty, J.E., 2015, Integrating linear-based uncertainty analyses into PEST++, in Maxwell, Reed, Hill, Mary, Zheng, Chunmiao, and Tonkin, Matt, eds., MODFLOW and more 2015, Modeling a complex world-Proceedings, Golden, Colorado, May 31-June 3, 2015, 559 p.
Wittman, J.W., Kelson, V., and Wilson, T., 2003, Final report: Source of supply investigation for Joplin, Missouri: Wittman Hydro Planning Associates, Inc., 97 p.

U.S. Geological Survey, 2015, National Water Information System web interface, accessed February 3, 2015, at https:// doi.org/10.5066/F7P55KJN.

U.S. Geological Survey, 2018, Regional and global climate, accessed March 22, 2018, at http://regclim.coas.oregonstate. edu:8080/thredds/mwbm_cmip5.html. 


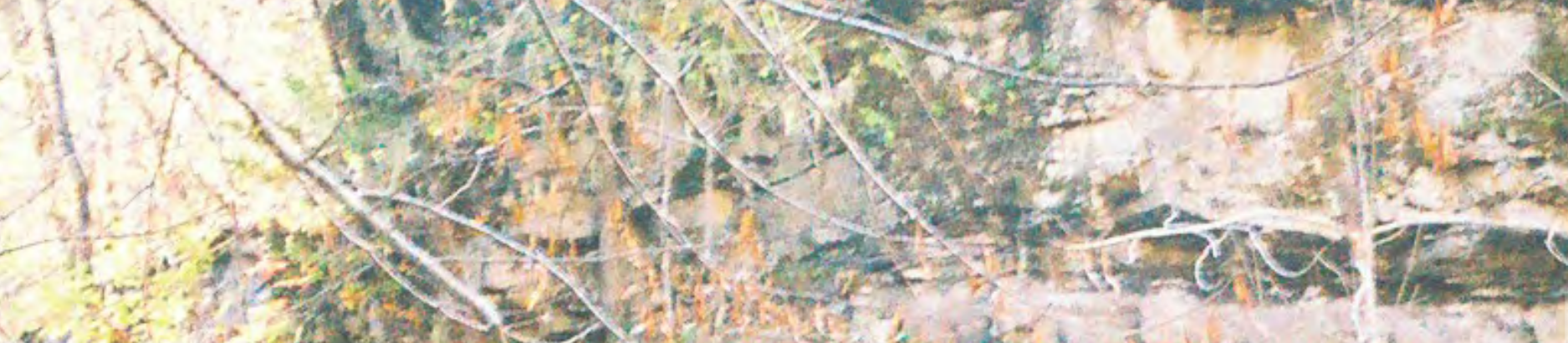

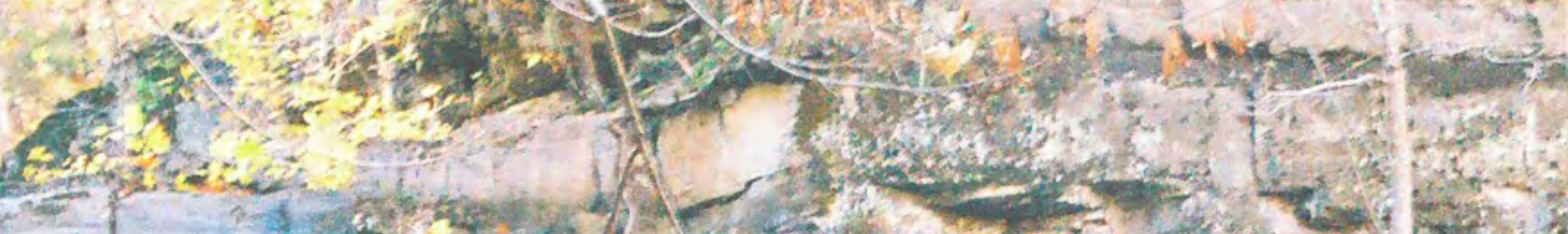

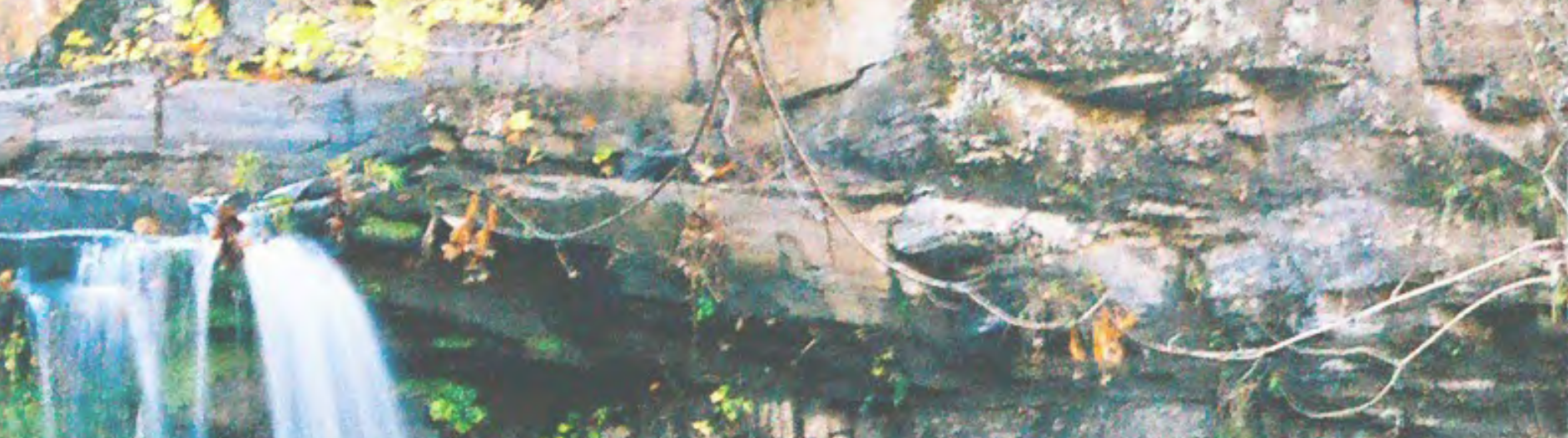

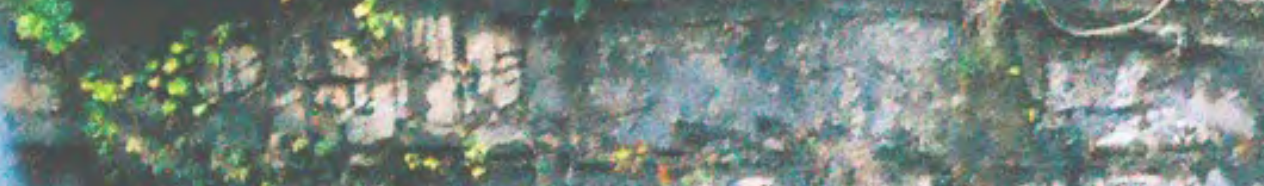

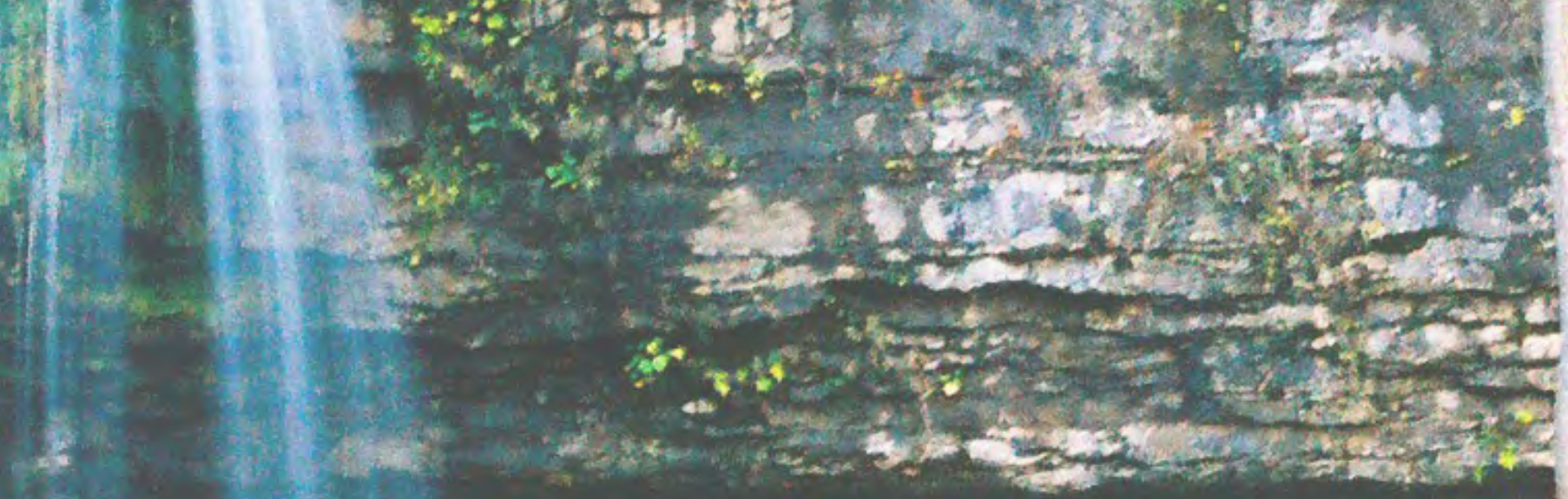

....

aw. 



\section{Appendix 1}

This appendix contains additional information regarding updated parameter estimates (table 1.1) and model fit for the Ozark groundwater availability model, version 1.1. The model results were evaluated through the calculation of the mean residual for the hydraulic heads. The mean of residuals indicates model bias depending on the magnitude and direction of the mean away from zero (fig. 1.1). An additional assessment of model error and of model fit to the observation data is accomplished through a plot of the observed water-level altitudes and simulated hydraulic head values (fig. 1.2). Simulated stream leakage and the 7-day, 2-year (7Q2) statistic values were used to assess the model estimates of discharge from the aquifer system to streams (fig. 1.3). As a final assessment of model fit, temporal trends of the model were examined through simulated and observed hydrographs in 10 selected wells completed in the Springfield Plateau aquifer, the Ozark aquifer, and the St. Francois aquifer (fig. 1.4).

Table 1.1. Final parameter estimates for the Ozark groundwater-flow model, version 1.1.-Continued

[All aquifer properties exclude Mississippi embayment values. $\mathrm{ft} / \mathrm{d}$, foot per day; $\mathrm{ft}$, foot; $\mathrm{ft}^{2} / \mathrm{d}$, foot squared per day]

\begin{tabular}{|c|c|c|c|c|}
\hline Parameter description & $\begin{array}{c}\text { Parameter } \\
\text { name }\end{array}$ & Value or range & Units & Model layer \\
\hline Hydraulic conductivity (horizontal) & hk1 & $6.14 \mathrm{e}-03$ to $3.21 \mathrm{e}-01$ & $\mathrm{ft} / \mathrm{d}$ & 1 \\
\hline Hydraulic conductivity (horizontal) & $\mathrm{hk} 2$ & 1.00 to 191.04 & $\mathrm{ft} / \mathrm{d}$ & 2 \\
\hline Hydraulic conductivity (horizontal) & hk3 & $2.00 \mathrm{e}-07$ to $1.27 \mathrm{e}-01$ & $\mathrm{ft} / \mathrm{d}$ & 3 \\
\hline Hydraulic conductivity (horizontal) & hk4 & $1.44 \mathrm{e}-03$ to $1.17 \mathrm{e}+01$ & $\mathrm{ft} / \mathrm{d}$ & 4 \\
\hline Hydraulic conductivity (horizontal) & hk5 & $1.44 \mathrm{e}-03$ to $5.24 \mathrm{e}-01$ & $\mathrm{ft} / \mathrm{d}$ & 5 \\
\hline Hydraulic conductivity (horizontal) & hk6 & 0.06 to 93.70 & $\mathrm{ft} / \mathrm{d}$ & 6 \\
\hline Hydraulic conductivity (horizontal) & hk7 & $1.00 \mathrm{e}-08$ to $4.00 \mathrm{e}-01$ & $\mathrm{ft} / \mathrm{d}$ & 7 \\
\hline Hydraulic conductivity (horizontal) & hk8 & 3.64 to 41.28 & $\mathrm{ft} / \mathrm{d}$ & 8 \\
\hline Hydraulic conductivity (horizontal) & hk9 & 3.64 to 41.28 & $\mathrm{ft} / \mathrm{d}$ & 9 \\
\hline Hydraulic conductivity (vertical) & $\mathrm{vk} 1$ & $6.14 \mathrm{e}-04$ to $3.21 \mathrm{e}-02$ & $\mathrm{ft} / \mathrm{d}$ & 1 \\
\hline Hydraulic conductivity (vertical) & $\mathrm{vk} 2$ & 0.10 to 19.10 & $\mathrm{ft} / \mathrm{d}$ & 2 \\
\hline Hydraulic conductivity (vertical) & $\mathrm{vk} 3$ & $2.00 \mathrm{e}-08$ to $1.27 \mathrm{e}-02$ & $\mathrm{ft} / \mathrm{d}$ & 3 \\
\hline Hydraulic conductivity (vertical) & $\mathrm{vk} 4$ & $1.44 \mathrm{e}-04$ to $1.17 \mathrm{e}+00$ & $\mathrm{ft} / \mathrm{d}$ & 4 \\
\hline Hydraulic conductivity (vertical) & $\mathrm{vk} 5$ & $1.44 \mathrm{e}-04$ to $5.24 \mathrm{e}-02$ & $\mathrm{ft} / \mathrm{d}$ & 5 \\
\hline Hydraulic conductivity (vertical) & vk6 & $6.37 \mathrm{e}-03$ to $9.37 \mathrm{e}+00$ & $\mathrm{ft} / \mathrm{d}$ & 6 \\
\hline Hydraulic conductivity (vertical) & $\mathrm{vk} 7$ & $1.00 \mathrm{e}-09$ to $4.00 \mathrm{e}-02$ & $\mathrm{ft} / \mathrm{d}$ & 7 \\
\hline Hydraulic conductivity (vertical) & $\mathrm{vk} 8$ & 0.36 to 4.13 & $\mathrm{ft} / \mathrm{d}$ & 8 \\
\hline Hydraulic conductivity (vertical) & vk9 & 0.36 to 4.13 & $\mathrm{ft} / \mathrm{d}$ & 9 \\
\hline Specific yield & syl & $4.55 \mathrm{e}-03$ & dimensionless & 1 \\
\hline Specific yield & sy2 & $3.83 e-03$ & dimensionless & 2 \\
\hline Specific yield & sy3 & 0.01 & dimensionless & 3 \\
\hline Specific yield & sy4 & $5.28 \mathrm{e}-04$ to $4.71 \mathrm{e}-03$ & dimensionless & 4 \\
\hline Specific yield & sy 5 & $5.28 \mathrm{e}-04$ & dimensionless & 5 \\
\hline Specific yield & sy6 & $2.69 \mathrm{e}-03$ to $5.00 \mathrm{e}-02$ & dimensionless & 6 \\
\hline Specific storage & ss 1 & $8.96 \mathrm{e}-06$ & $1 / \mathrm{ft}$ & 1 \\
\hline Specific storage & ss2 & $3.49 \mathrm{e}-06$ & $1 / \mathrm{ft}$ & 2 \\
\hline Specific storage & ss 3 & $2.94 \mathrm{e}-06$ & $1 / \mathrm{ft}$ & 3 \\
\hline Specific storage & ss4 & $3.90 \mathrm{e}-07$ to $5.27 \mathrm{e}-07$ & $1 / \mathrm{ft}$ & 4 \\
\hline Specific storage & ss 5 & $3.90 \mathrm{e}-07$ & $1 / \mathrm{ft}$ & 5 \\
\hline
\end{tabular}


Table 1.1. Final parameter estimates for the Ozark groundwater-flow model, version 1.1._Continued

[All aquifer properties exclude Mississippi embayment values. $\mathrm{ft} / \mathrm{d}$, foot per day; $\mathrm{ft}$, foot; $\mathrm{ft}^{2} / \mathrm{d}$, foot squared per day]

\begin{tabular}{|c|c|c|c|c|}
\hline Parameter description & $\begin{array}{c}\text { Parameter } \\
\text { name }\end{array}$ & Value or range & Units & Model layer \\
\hline Specific storage & ss6 & $3.59 \mathrm{e}-07$ to $4.70 \mathrm{e}-05$ & $1 / \mathrm{ft}$ & 6 \\
\hline Specific storage & ss 7 & $2.62 \mathrm{e}-06$ & $1 / \mathrm{ft}$ & 7 \\
\hline Specific storage & ss 8 & $6.07 e-07$ & $1 / \mathrm{ft}$ & 8 \\
\hline Specific storage & ss9 & $6.07 \mathrm{e}-07$ & $1 / \mathrm{ft}$ & 9 \\
\hline Recharge pilot points & rch & $0.00 \mathrm{e}+00$ to $8.34 \mathrm{e}+01$ & in/year & multiple \\
\hline Temporal recharge multipliers & tsrch1 & 1.25 & dimensionless & multiple \\
\hline Temporal recharge multipliers & $\operatorname{tsrch} 2$ & 1.25 & dimensionless & multiple \\
\hline Temporal recharge multipliers & $\operatorname{tsrch} 3$ & 1.25 & dimensionless & multiple \\
\hline Temporal recharge multipliers & tsrch4 & 0.96 & dimensionless & multiple \\
\hline Temporal recharge multipliers & $\operatorname{tsrch} 5$ & 0.82 & dimensionless & multiple \\
\hline Temporal recharge multipliers & tsrch6 & 1.16 & dimensionless & multiple \\
\hline Temporal recharge multipliers & $\operatorname{tsrch} 7$ & 1.22 & dimensionless & multiple \\
\hline Temporal recharge multipliers & tsrch 8 & 0.84 & dimensionless & multiple \\
\hline Temporal recharge multipliers & tsrch9 & 0.77 & dimensionless & multiple \\
\hline Temporal recharge multipliers & tsrch10 & 0.44 & dimensionless & multiple \\
\hline Temporal recharge multipliers & tsrch11 & 0.95 & dimensionless & multiple \\
\hline Temporal recharge multipliers & tsrch12 & 1.75 & dimensionless & multiple \\
\hline Temporal recharge multipliers & tsrch13 & 1.01 & dimensionless & multiple \\
\hline Temporal recharge multipliers & tsrch14 & 1.20 & dimensionless & multiple \\
\hline Temporal recharge multipliers & tsrch15 & 0.75 & dimensionless & multiple \\
\hline Temporal recharge multipliers & tsrch16 & 1.41 & dimensionless & multiple \\
\hline Temporal recharge multipliers & tsrch17 & 1.11 & dimensionless & multiple \\
\hline Temporal recharge multipliers & tsrch18 & 1.13 & dimensionless & multiple \\
\hline Temporal recharge multipliers & tsrch19 & 0.36 & dimensionless & multiple \\
\hline Temporal recharge multipliers & tsrch20 & 1.56 & dimensionless & multiple \\
\hline Temporal recharge multipliers & $\operatorname{tsrch} 21$ & 2.03 & dimensionless & multiple \\
\hline Temporal recharge multipliers & $\operatorname{tsrch} 22$ & 1.43 & dimensionless & multiple \\
\hline Temporal recharge multipliers & tsrch23 & 1.59 & dimensionless & multiple \\
\hline Temporal recharge multipliers & tsrch24 & 2.23 & dimensionless & multiple \\
\hline Temporal recharge multipliers & $\operatorname{tsrch} 25$ & 1.78 & dimensionless & multiple \\
\hline Temporal recharge multipliers & $\operatorname{tsrch} 26$ & 1.81 & dimensionless & multiple \\
\hline Temporal recharge multipliers & $\operatorname{tsrch} 27$ & 1.68 & dimensionless & multiple \\
\hline Temporal recharge multipliers & $\operatorname{tsrch} 28$ & 1.21 & dimensionless & multiple \\
\hline Streambed conductance & huc103 & 2.25 to $252,007.55$ & $\mathrm{ft}^{2} / \mathrm{d}$ & multiple \\
\hline Streambed conductance & huc105 & 1.46 to $702,377.67$ & $\mathrm{ft}^{2} / \mathrm{d}$ & multiple \\
\hline Streambed conductance & huc106 & 57.35 to $459,043.40$ & $\mathrm{ft}^{2} / \mathrm{d}$ & multiple \\
\hline Streambed conductance & huc107 & 4.90 to $83,232.99$ & $\mathrm{ft}^{2} / \mathrm{d}$ & multiple \\
\hline Streambed conductance & huc108 & 18.64 to $150,218.55$ & $\mathrm{ft}^{2} / \mathrm{d}$ & multiple \\
\hline Streambed conductance & huc114 & 1.17 to $49,495.58$ & $\mathrm{ft}^{2} / \mathrm{d}$ & multiple \\
\hline Streambed conductance & huc116 & 0.17 to $291,771.00$ & $\mathrm{ft}^{2} / \mathrm{d}$ & multiple \\
\hline
\end{tabular}


Table 1.1. Final parameter estimates for the Ozark groundwater-flow model, version 1.1. - Continued

[All aquifer properties exclude Mississippi embayment values. $\mathrm{ft} / \mathrm{d}$, foot per day; $\mathrm{ft}$, foot; $\mathrm{ft}^{2} / \mathrm{d}$, foot squared per day]

\begin{tabular}{|c|c|c|c|c|}
\hline Parameter description & $\begin{array}{c}\text { Parameter } \\
\text { name }\end{array}$ & Value or range & Units & Model layer \\
\hline Streambed conductance & huc117 & 2.27 to $326,834.09$ & $\mathrm{ft}^{2} / \mathrm{d}$ & multiple \\
\hline Streambed conductance & huc118 & 4.74 to $179,740.60$ & $\mathrm{ft}^{2} / \mathrm{d}$ & multiple \\
\hline Streambed conductance & huc119 & 8.26 to $208,010.33$ & $\mathrm{ft}^{2} / \mathrm{d}$ & multiple \\
\hline Streambed conductance & huc12 & 8.59 to $664,106.94$ & $\mathrm{ft}^{2} / \mathrm{d}$ & multiple \\
\hline Streambed conductance & huc120 & 2.81 to $20,511.80$ & $\mathrm{ft}^{2} / \mathrm{d}$ & multiple \\
\hline Streambed conductance & huc122 & $559,899.54$ & $\mathrm{ft}^{2} / \mathrm{d}$ & multiple \\
\hline Streambed conductance & huc130 & 7.84 to $383,902.08$ & $\mathrm{ft}^{2} / \mathrm{d}$ & multiple \\
\hline Streambed conductance & huc131 & 340.60 to $1,714.00$ & $\mathrm{ft}^{2} / \mathrm{d}$ & multiple \\
\hline Streambed conductance & huc132 & 3.91 to $38,401.01$ & $\mathrm{ft}^{2} / \mathrm{d}$ & multiple \\
\hline Streambed conductance & huc134 & 4.21 to $168,283.75$ & $\mathrm{ft}^{2} / \mathrm{d}$ & multiple \\
\hline Streambed conductance & huc135 & 0.14 to $20,693.06$ & $\mathrm{ft}^{2} / \mathrm{d}$ & multiple \\
\hline Streambed conductance & huc136 & 28.30 to $13,389.55$ & $\mathrm{ft}^{2} / \mathrm{d}$ & multiple \\
\hline Streambed conductance & huc138 & 13.14 to $54,109.02$ & $\mathrm{ft}^{2} / \mathrm{d}$ & multiple \\
\hline Streambed conductance & huc140 & 0.55 to $63,070.31$ & $\mathrm{ft}^{2} / \mathrm{d}$ & multiple \\
\hline Streambed conductance & huc141 & 0.70 to $41,191.99$ & $\mathrm{ft}^{2} / \mathrm{d}$ & multiple \\
\hline Streambed conductance & huc146 & 0.52 to $75,094.76$ & $\mathrm{ft}^{2} / \mathrm{d}$ & multiple \\
\hline Streambed conductance & huc147 & 358.83 to $669,014.58$ & $\mathrm{ft}^{2} / \mathrm{d}$ & multiple \\
\hline Streambed conductance & huc149 & 10.20 to $64,893.25$ & $\mathrm{ft}^{2} / \mathrm{d}$ & multiple \\
\hline Streambed conductance & huc150 & 128.63 to $35,130.08$ & $\mathrm{ft}^{2} / \mathrm{d}$ & multiple \\
\hline Streambed conductance & huc151 & 4.35 to $46,252.46$ & $\mathrm{ft}^{2} / \mathrm{d}$ & multiple \\
\hline Streambed conductance & huc153 & 103.38 to $10,021.21$ & $\mathrm{ft}^{2} / \mathrm{d}$ & multiple \\
\hline Streambed conductance & huc154 & 0.05 to $322,894.70$ & $\mathrm{ft}^{2} / \mathrm{d}$ & multiple \\
\hline Streambed conductance & huc170 & 2.70 to $45,926.96$ & $\mathrm{ft}^{2} / \mathrm{d}$ & multiple \\
\hline Streambed conductance & huc176 & 8.50 to $207,959.66$ & $\mathrm{ft}^{2} / \mathrm{d}$ & multiple \\
\hline Streambed conductance & huc177 & 0.28 to $57,010.92$ & $\mathrm{ft}^{2} / \mathrm{d}$ & multiple \\
\hline Streambed conductance & huc178 & 4.49 to $90,697.67$ & $\mathrm{ft}^{2} / \mathrm{d}$ & multiple \\
\hline Streambed conductance & huc179 & 26.08 to $141,080.48$ & $\mathrm{ft}^{2} / \mathrm{d}$ & multiple \\
\hline Streambed conductance & huc180 & 33.70 to $12,512.50$ & $\mathrm{ft}^{2} / \mathrm{d}$ & multiple \\
\hline Streambed conductance & huc182 & 99.46 to $111,272.99$ & $\mathrm{ft}^{2} / \mathrm{d}$ & multiple \\
\hline Streambed conductance & huc183 & 4.39 to $93,831.63$ & $\mathrm{ft}^{2} / \mathrm{d}$ & multiple \\
\hline Streambed conductance & huc184 & 0.29 to $127,314.33$ & $\mathrm{ft}^{2} / \mathrm{d}$ & multiple \\
\hline Streambed conductance & huc187 & 9.17 to $70,127.45$ & $\mathrm{ft}^{2} / \mathrm{d}$ & multiple \\
\hline Streambed conductance & huc188 & 48.57 to $583,800.32$ & $\mathrm{ft}^{2} / \mathrm{d}$ & multiple \\
\hline Streambed conductance & huc208 & 949.59 to $52,659,311.40$ & $\mathrm{ft}^{2} / \mathrm{d}$ & multiple \\
\hline Streambed conductance & huc214 & 2.51 to $159,546.98$ & $\mathrm{ft}^{2} / \mathrm{d}$ & multiple \\
\hline Streambed conductance & huc218 & 0.15 to $681,577.72$ & $\mathrm{ft}^{2} / \mathrm{d}$ & multiple \\
\hline Streambed conductance & huc241 & 0.41 to $424,606.15$ & $\mathrm{ft}^{2} / \mathrm{d}$ & multiple \\
\hline Streambed conductance & huc242 & 2.19 to $54,295.00$ & $\mathrm{ft}^{2} / \mathrm{d}$ & multiple \\
\hline Streambed conductance & huc243 & 3.12 to $545,916.13$ & $\mathrm{ft}^{2} / \mathrm{d}$ & multiple \\
\hline Streambed conductance & huc251 & 15.25 to $26,320.59$ & $\mathrm{ft}^{2} / \mathrm{d}$ & multiple \\
\hline
\end{tabular}


Table 1.1. Final parameter estimates for the Ozark groundwater-flow model, version 1.1._Continued

[All aquifer properties exclude Mississippi embayment values. $\mathrm{ft} / \mathrm{d}$, foot per day; $\mathrm{ft}$, foot; $\mathrm{ft}^{2} / \mathrm{d}$, foot squared per day]

\begin{tabular}{|c|c|c|c|c|}
\hline Parameter description & $\begin{array}{c}\text { Parameter } \\
\text { name }\end{array}$ & Value or range & Units & Model layer \\
\hline Streambed conductance & huc77 & 5.58 to $268,638.33$ & $\mathrm{ft}^{2} / \mathrm{d}$ & multiple \\
\hline Streambed conductance & huc78 & 12.32 to $187,324.32$ & $\mathrm{ft}^{2} / \mathrm{d}$ & multiple \\
\hline Streambed conductance & huc79 & 0.07 to $94,885.14$ & $\mathrm{ft}^{2} / \mathrm{d}$ & multiple \\
\hline Streambed conductance & huc80 & 3.14 to $129,859.03$ & $\mathrm{ft}^{2} / \mathrm{d}$ & multiple \\
\hline Streambed conductance & huc81 & 9.45 to $773,708.89$ & $\mathrm{ft}^{2} / \mathrm{d}$ & multiple \\
\hline Streambed conductance & huc82 & 5.10 to $432,075.26$ & $\mathrm{ft}^{2} / \mathrm{d}$ & multiple \\
\hline Streambed conductance & huc83 & 1.76 to $62,579.21$ & $\mathrm{ft}^{2} / \mathrm{d}$ & multiple \\
\hline Streambed conductance & huc84 & 11.86 to $911,069.54$ & $\mathrm{ft}^{2} / \mathrm{d}$ & multiple \\
\hline Streambed conductance & huc90 & 15.88 to $121,904.61$ & $\mathrm{ft}^{2} / \mathrm{d}$ & multiple \\
\hline Streambed conductance & huc98 & 7.71 to $1,255,615.89$ & $\mathrm{ft}^{2} / \mathrm{d}$ & multiple \\
\hline Streambed conductance & huc99 & 6.47 to $1,421,376.07$ & $\mathrm{ft}^{2} / \mathrm{d}$ & multiple \\
\hline General head multiplier & ghb-1 & 0.68 & dimensionless & multiple \\
\hline Constant head multiplier & chd-1 & 0.81 & dimensionless & multiple \\
\hline Constant head multiplier & chd-6 & 0.77 & dimensionless & multiple \\
\hline Constant head multiplier & chd-9 & 0.58 & dimensionless & multiple \\
\hline Horizontal flow multiplier & hfb-1 & 3.93 & dimensionless & multiple \\
\hline Pumping multiplier & wel-0 & 1.00 & dimensionless & multiple \\
\hline Pumping multiplier & wel-1 & 1.48 & dimensionless & multiple \\
\hline Pumping multiplier & wel-2 & 1.29 & dimensionless & multiple \\
\hline Pumping multiplier & wel-3 & 1.08 & dimensionless & multiple \\
\hline Pumping multiplier & wel-4 & 1.44 & dimensionless & multiple \\
\hline Pumping multiplier & wel-5 & 1.45 & dimensionless & multiple \\
\hline Pumping multiplier & wel-6 & 1.44 & dimensionless & multiple \\
\hline Pumping multiplier & wel-7 & 1.53 & dimensionless & multiple \\
\hline Pumping multiplier & wel-8 & 1.48 & dimensionless & multiple \\
\hline Pumping multiplier & wel-9 & 1.41 & dimensionless & multiple \\
\hline Pumping multiplier & wel-10 & 1.01 & dimensionless & multiple \\
\hline Pumping multiplier & wel-11 & 1.13 & dimensionless & multiple \\
\hline Pumping multiplier & wel-12 & 1.07 & dimensionless & multiple \\
\hline Pumping multiplier & wel-13 & 0.89 & dimensionless & multiple \\
\hline Pumping multiplier & wel-14 & 0.89 & dimensionless & multiple \\
\hline Pumping multiplier & wel-15 & 0.98 & dimensionless & multiple \\
\hline Pumping multiplier & wel-16 & 0.94 & dimensionless & multiple \\
\hline Pumping multiplier & wel-17 & 0.96 & dimensionless & multiple \\
\hline Pumping multiplier & wel-18 & 1.02 & dimensionless & multiple \\
\hline Pumping multiplier & wel-19 & 1.01 & dimensionless & multiple \\
\hline Pumping multiplier & wel-20 & 1.04 & dimensionless & multiple \\
\hline Pumping multiplier & wel-21 & 0.48 & dimensionless & multiple \\
\hline Pumping multiplier & wel-22 & 1.02 & dimensionless & multiple \\
\hline Pumping multiplier & wel-23 & 0.45 & dimensionless & multiple \\
\hline
\end{tabular}


Table 1.1. Final parameter estimates for the Ozark groundwater-flow model, version 1.1.-Continued

[All aquifer properties exclude Mississippi embayment values. $\mathrm{ft} / \mathrm{d}$, foot per day; $\mathrm{ft}$, foot; $\mathrm{ft}^{2} / \mathrm{d}$, foot squared per day]

\begin{tabular}{|c|c|c|c|c|}
\hline Parameter description & $\begin{array}{l}\text { Parameter } \\
\text { name }\end{array}$ & Value or range & Units & Model layer \\
\hline Pumping multiplier & wel-24 & 1.00 & dimensionless & multiple \\
\hline Pumping multiplier & wel-25 & 0.76 & dimensionless & multiple \\
\hline Pumping multiplier & wel-26 & 0.71 & dimensionless & multiple \\
\hline Pumping multiplier & wel-27 & 1.00 & dimensionless & multiple \\
\hline Pumping multiplier & wel-28 & 1.01 & dimensionless & multiple \\
\hline Pumping multiplier & wel-29 & 0.45 & dimensionless & multiple \\
\hline Pumping multiplier & wel-30 & 0.94 & dimensionless & multiple \\
\hline Pumping multiplier & wel-31 & 0.60 & dimensionless & multiple \\
\hline Pumping multiplier & wel-32 & 0.45 & dimensionless & multiple \\
\hline Pumping multiplier & wel-33 & 0.61 & dimensionless & multiple \\
\hline Pumping multiplier & wel-34 & 0.45 & dimensionless & multiple \\
\hline Pumping multiplier & wel-35 & 0.67 & dimensionless & multiple \\
\hline Pumping multiplier & wel-36 & 0.70 & dimensionless & multiple \\
\hline Pumping multiplier & wel-37 & 0.72 & dimensionless & multiple \\
\hline Pumping multiplier & wel-38 & 0.66 & dimensionless & multiple \\
\hline Pumping multiplier & wel-39 & 0.88 & dimensionless & multiple \\
\hline Pumping multiplier & wel-40 & 0.63 & dimensionless & multiple \\
\hline Pumping multiplier & wel-41 & 0.98 & dimensionless & multiple \\
\hline Pumping multiplier & wel-42 & 2.44 & dimensionless & multiple \\
\hline Pumping multiplier & wel-43 & 1.25 & dimensionless & multiple \\
\hline Pumping multiplier & wel-44 & 1.37 & dimensionless & multiple \\
\hline Pumping multiplier & wel-45 & 1.12 & dimensionless & multiple \\
\hline Pumping multiplier & wel-46 & 1.37 & dimensionless & multiple \\
\hline Pumping multiplier & wel-47 & 2.22 & dimensionless & multiple \\
\hline Pumping multiplier & wel-48 & 1.15 & dimensionless & multiple \\
\hline Pumping multiplier & wel-49 & 1.36 & dimensionless & multiple \\
\hline Pumping multiplier & wel-50 & 1.07 & dimensionless & multiple \\
\hline Pumping multiplier & wel-51 & 0.47 & dimensionless & multiple \\
\hline Pumping multiplier & wel-52 & 1.10 & dimensionless & multiple \\
\hline Pumping multiplier & wel-53 & 1.05 & dimensionless & multiple \\
\hline Pumping multiplier & wel-54 & 1.61 & dimensionless & multiple \\
\hline Pumping multiplier & wel-55 & 1.03 & dimensionless & multiple \\
\hline Pumping multiplier & wel-56 & 1.04 & dimensionless & multiple \\
\hline Pumping multiplier & wel-57 & 1.46 & dimensionless & multiple \\
\hline Pumping multiplier & wel-58 & 1.02 & dimensionless & multiple \\
\hline Pumping multiplier & wel-59 & 0.95 & dimensionless & multiple \\
\hline Pumping multiplier & wel-60 & 0.65 & dimensionless & multiple \\
\hline Pumping multiplier & wel-61 & 0.64 & dimensionless & multiple \\
\hline Pumping multiplier & wel-62 & 1.00 & dimensionless & multiple \\
\hline Pumping multiplier & wel-63 & 0.99 & dimensionless & multiple \\
\hline
\end{tabular}


Table 1.1. Final parameter estimates for the Ozark groundwater-flow model, version 1.1. - Continued

[All aquifer properties exclude Mississippi embayment values. $\mathrm{ft} / \mathrm{d}$, foot per day; $\mathrm{ft}$, foot; $\mathrm{ft}^{2} / \mathrm{d}$, foot squared per day]

\begin{tabular}{|c|c|c|c|c|}
\hline Parameter description & $\begin{array}{c}\text { Parameter } \\
\text { name }\end{array}$ & Value or range & Units & Model layer \\
\hline Pumping multiplier & wel-64 & 0.73 & dimensionless & multiple \\
\hline Pumping multiplier & wel-65 & 1.40 & dimensionless & multiple \\
\hline Pumping multiplier & wel-66 & 1.01 & dimensionless & multiple \\
\hline Pumping multiplier & wel-67 & 0.93 & dimensionless & multiple \\
\hline Pumping multiplier & wel-68 & 0.64 & dimensionless & multiple \\
\hline Pumping multiplier & wel-69 & 0.93 & dimensionless & multiple \\
\hline Pumping multiplier & wel-70 & 0.63 & dimensionless & multiple \\
\hline Pumping multiplier & wel-71 & 0.97 & dimensionless & multiple \\
\hline Pumping multiplier & wel-72 & 0.45 & dimensionless & multiple \\
\hline Pumping multiplier & wel-73 & 0.93 & dimensionless & multiple \\
\hline Pumping multiplier & wel-74 & 0.67 & dimensionless & multiple \\
\hline Pumping multiplier & wel-75 & 0.69 & dimensionless & multiple \\
\hline Pumping multiplier & wel-76 & 1.08 & dimensionless & multiple \\
\hline Pumping multiplier & wel-77 & 1.50 & dimensionless & multiple \\
\hline Pumping multiplier & wel-78 & 1.00 & dimensionless & multiple \\
\hline Pumping multiplier & wel-79 & 1.00 & dimensionless & multiple \\
\hline
\end{tabular}




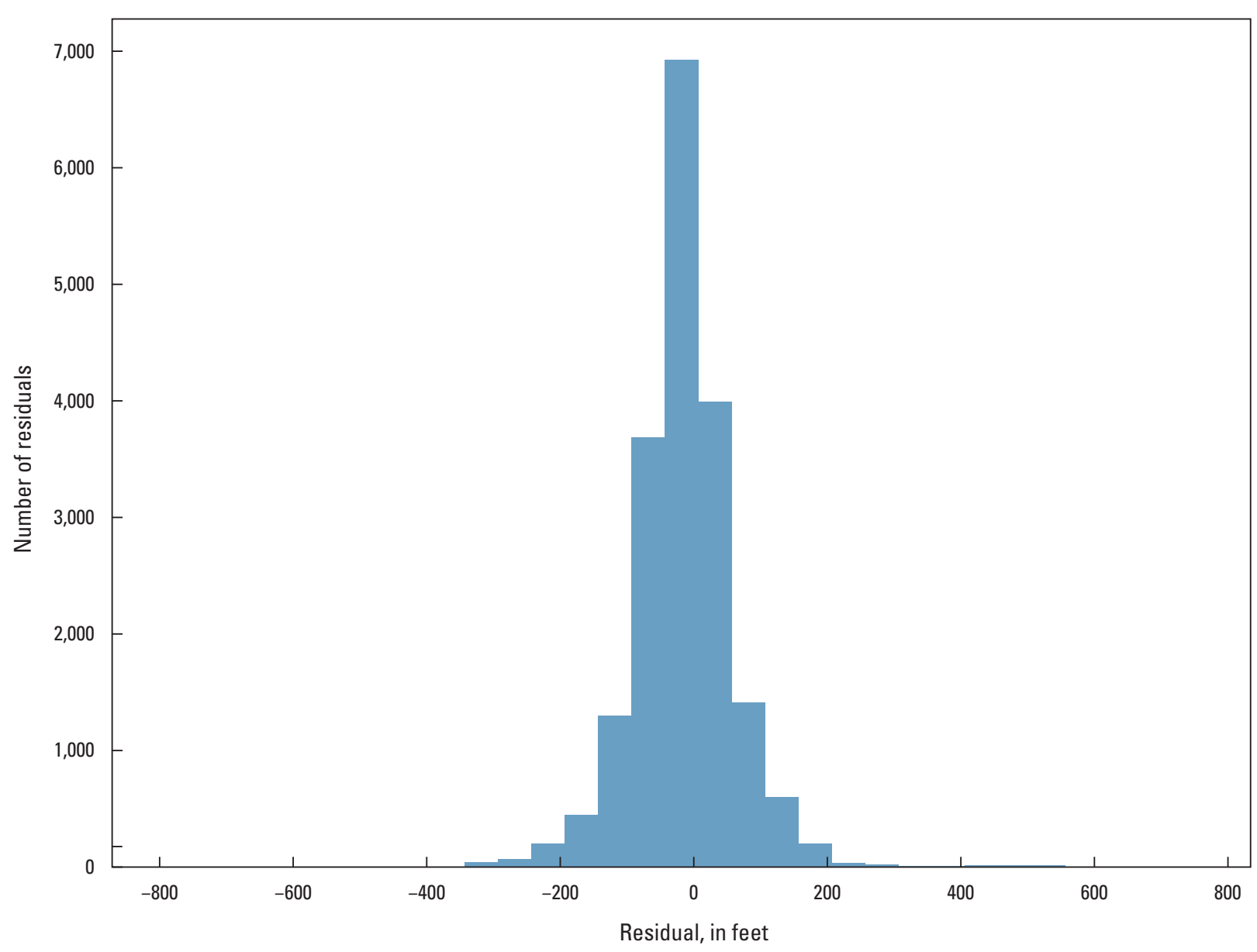

Figure 1.1. Distribution of unweighted hydraulic-head residuals. 


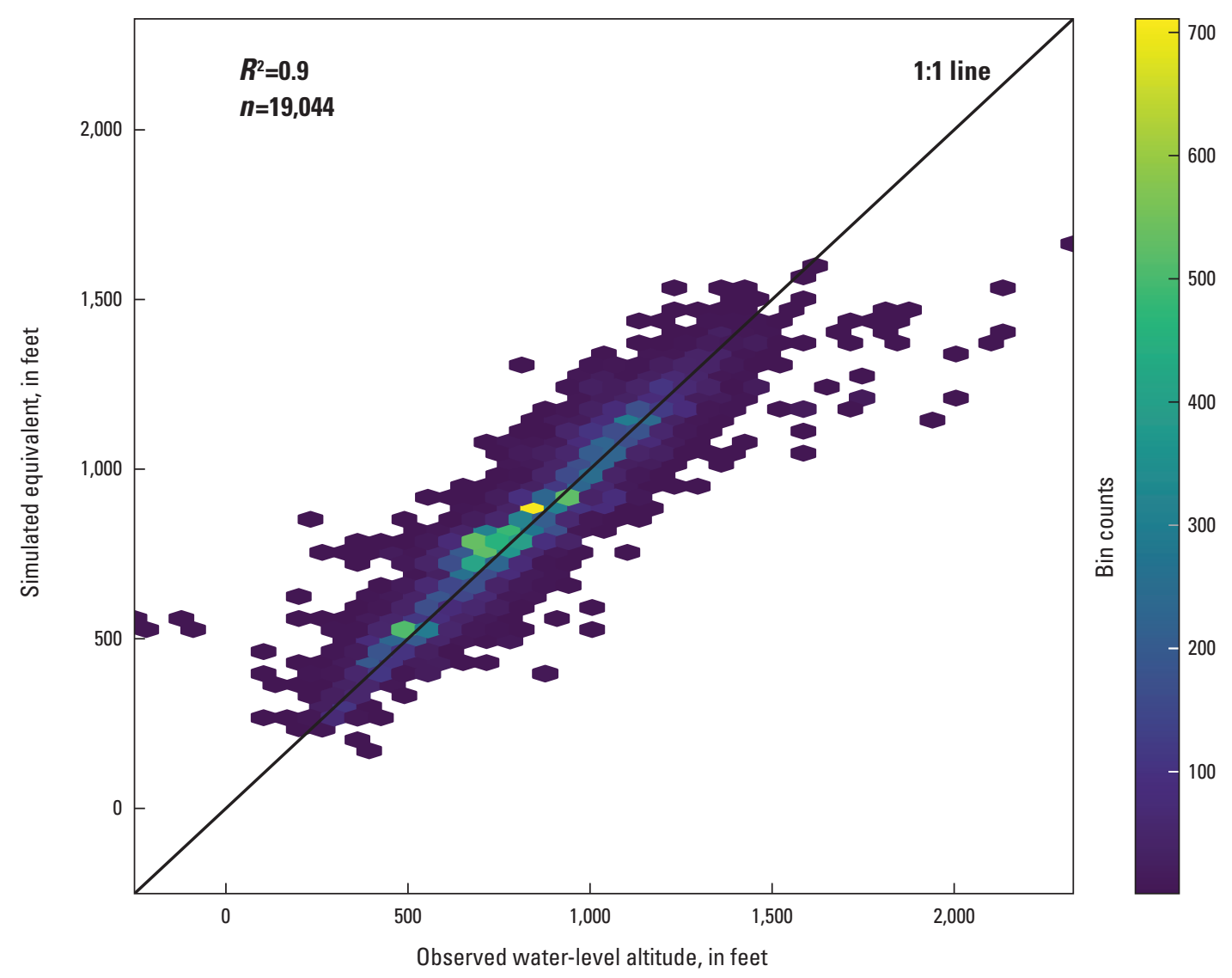

Figure 1.2. Unweighted simulated hydraulic-head values plotted against observed water-level altitudes. 


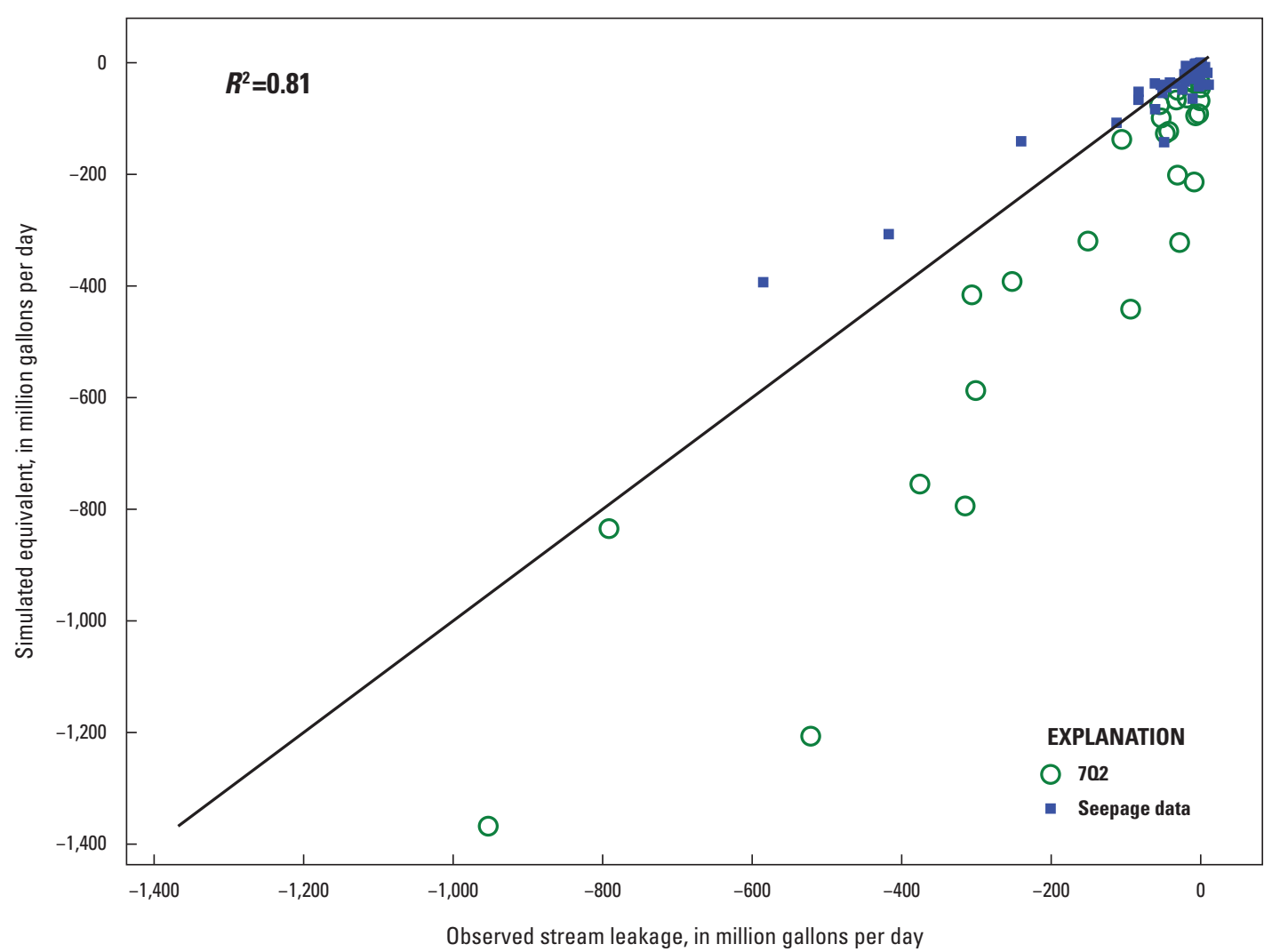

Figure 1.3. Simulated stream leakage plotted against observed stream leakage (seepage data from Knierim and others [2015]). The 7-day, 2-year (702) annual low-flow statistic is the annual 7-day minimum flow with a 2-year recurrence interval (nonexceedance probability of 50 percent). 

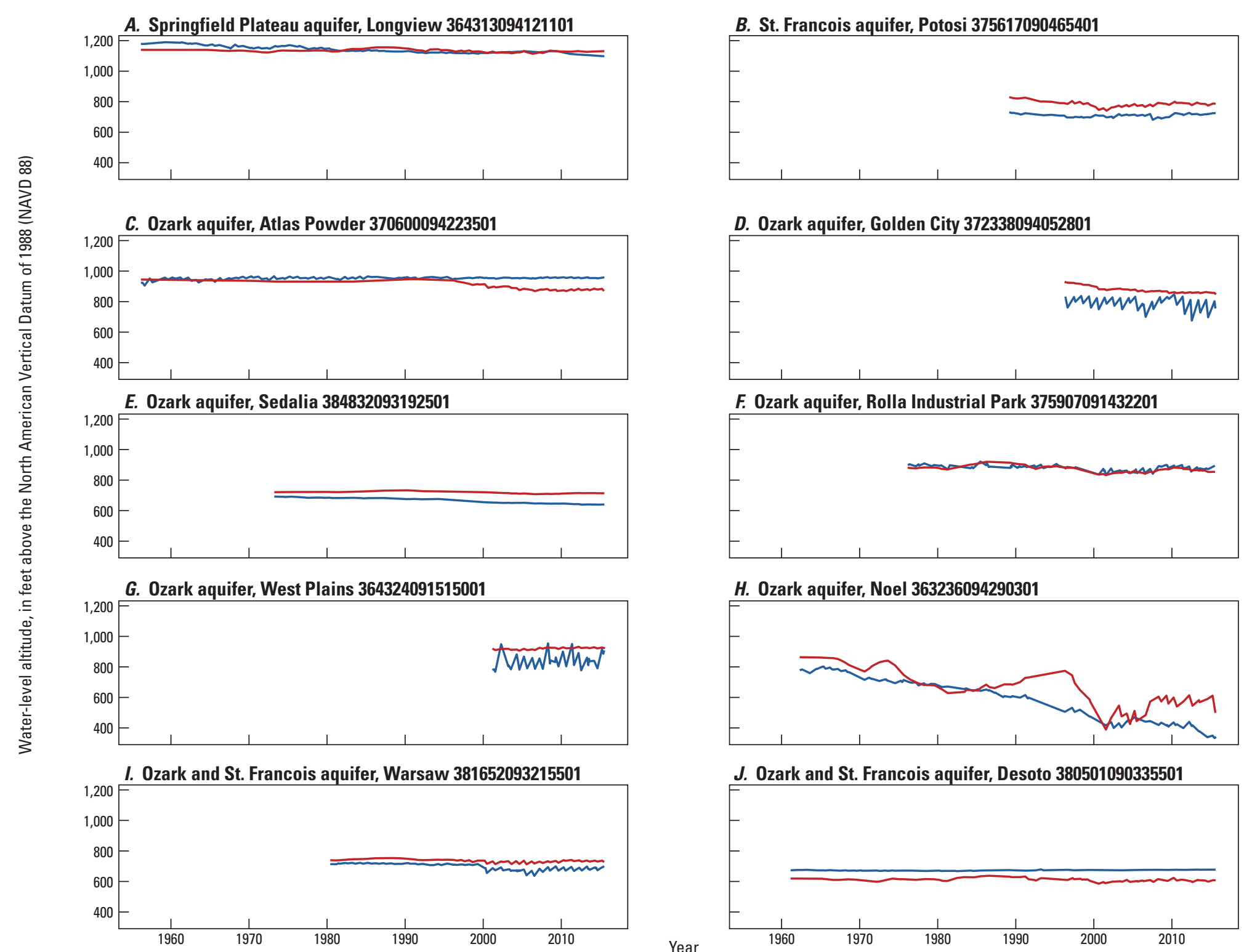

EXPLANATION

- Observed

_ Simulated

Figure 1.4. Simulated and observed water levels in select U.S. Geological Survey real-time observation wells (U.S. Geological Survey, 2015). The number above each hydrograph is the U.S. Geological Survey station number. 


\section{Appendix 2}

This appendix contains additional information regarding the linear uncertainty analyses used to quantify: (1) parameter uncertainty, (2) prediction uncertainty, (3) the worth of data pertaining directly to parameters, and (4) the worth of data pertaining indirectly to observations, when using the three scenarios simulating future potential conditions. Head forecast identifiers are arbitrary numbers assigned to each head prediction for the purpose of differentiation. Some head predictions are located at the same latitude and longitude but are located in different model layers (table 2.1).

\section{Parameter Uncertainty}

The prior parameter uncertainty estimates for adjustable model parameters in the predictive analysis were based on a range of potential values for the parameters prior to the history-matching process. Typically, this stochastic information is derived from expert knowledge, literature values, field tests, or earlier models. History-matching produces the best-fit parameter values, and the posterior (after history matching) uncertainty of adjustable model parameters then can be estimated by using linear uncertainty analysis. Schur's complement (Meyer, 2000) for conditional uncertainty propagation (White and others, 2015) is

$$
\overline{\Sigma_{\theta}}=\Sigma_{\theta}-\Sigma_{\theta} J^{T}\left(J \Sigma_{\theta} J^{T}+\Sigma_{\varepsilon}\right)^{-1} J \Sigma_{\theta}
$$

where

$\overline{\Sigma_{\theta}}$ is the posterior parameter covariance matrix,

$\Sigma_{\theta}$ is the prior parameter covariance matrix,

$J \quad$ is the Jacobian matrix of partial first derivatives of observations with respect to parameters, and

$\Sigma_{\varepsilon}$ is the covariance matrix of observation noise.

The second term in the above equation $\left(\Sigma_{\theta} J^{T}\left(J \Sigma_{\theta} J^{T}+\Sigma_{\varepsilon}\right)^{-1} J \Sigma_{\theta}\right)$ encapsulates the conditioning provided by the observations through linear mapping of information from observations to parameters via the Jacobian matrix. Use of equation 2.1 assumes (1) a linear relationship between adjustable parameters and model-simulated observation equivalents and (2) multivariate Gaussian (or log-Gaussian) distributions to describe the stochastic character of parameters, predictions, and observation noise (Fienen and others, 2010; White and others, 2015). Therefore, the primary quantitative metric for uncertainty in a linear framework is variance (Doherty and others, 2010).

Comparison of the prior and posterior variances associated with adjustable model parameters illustrates how the observations used in the history-matching process informs the adjustable model parameters. Similar prior and posterior variances for a given parameter imply that the observation dataset contributed little to inform that specific parameter. Conversely, a posterior variance that is smaller than the prior variance for a given parameter implies that the parameter is well informed by the observation dataset.

For example, the generalized head boundary multiplier has a posterior variance similar to the prior variance, which indicates that the observation dataset failed to decrease the uncertainty through history matching (table 3 , main text), likely because of the relatively few numbers of observations and stress effects in the Ozark system near the Mississippi embayment. Again, the reduction in uncertainty tends to increase in areas with larger numbers of observations and stressed areas of the model. Specific storage parameters of the St. Francois aquifer and the St. Francois confining unit are well informed by the observation dataset, but the horizontal hydraulic conductivity of the St. Francois aquifer and the vertical hydraulic conductivity of the St. Francois confining unit are not (table 3, main text). Head observations, therefore seem to provide more information for these deeper units than flow observations such as stream leakage, because most of the area of the units is below the influence of groundwatersurface-water interaction. Uncertainty reduction of parameters related to aquifer properties of the lower Ozark aquifer tends to be low, though the differences in the maximum and minimum reduction tend to be large, indicating that uncertainty at some pilot-point parameters was greatly reduced, likely in areas of higher stress with more nearby observations. Specific storage and specific yield parameters for the middle Ozark aquifer were only marginally informed by the observation dataset, potentially because observations are included in the confined and unconfined parts of the unit. Most of the horizontal hydraulic conductivity pilot-point parameters in the upper Ozark aquifer have posterior variances similar to the prior variances, which indicates that the observation dataset failed to decrease the uncertainties of these parameters through history matching (table 3, main text). The specific storage parameter for the St. Francois aquifer is well informed by the observation dataset, as the posterior variance is much lower than the prior variance. Similarly, the specific yield parameter for the Springfield Plateau aquifer is well informed by the observation dataset. Specific yield parameters for the Ozark confining unit are only marginally informed by the observation dataset. The specific storage parameter for the Western Interior Plains confining system is well informed by the observation dataset, and the specific yield parameter is only marginally informed by the observation dataset.

Differences between prior and posterior variances for most pilot-point parameters were mixed. Some pilot-point parameter groups had a higher proportion of larger reductions in posterior variances than other pilot-point parameter groups - for example, horizontal hydraulic conductivity in the lower Ozark aquifer and vertical hydraulic conductivities in 
Table 2.1. Head forecast identifiers and associated model layers for the Ozark groundwater-flow model, version 1.1.

\begin{tabular}{|c|c|c|c|c|c|}
\hline $\begin{array}{c}\text { Head forecast } \\
\text { identifier } \\
\text { (see figs. 15-17) }\end{array}$ & Model layer & $\begin{array}{c}\text { Head forecast } \\
\text { identifier } \\
\text { (see figs. 15-17) }\end{array}$ & Model layer & $\begin{array}{c}\text { Head forecast } \\
\text { identifier } \\
\text { (see figs. 15-17) }\end{array}$ & Model layer \\
\hline 0 & 6 & 31 & 6 & 62 & 6 \\
\hline 1 & 9 & 32 & 6 & 63 & 6 \\
\hline 2 & 6 & 33 & 6 & 65 & 6 \\
\hline 3 & 2 & 34 & 9 & 66 & 6 \\
\hline 4 & 6 & 35 & 9 & 67 & 6 \\
\hline 5 & 6 & 36 & 6 & 68 & 6 \\
\hline 6 & 6 & 37 & 6 & 69 & 6 \\
\hline 7 & 6 & 38 & 6 & 70 & 6 \\
\hline 8 & 6 & 39 & 6 & 71 & 6 \\
\hline 9 & 6 & 40 & 6 & 72 & 6 \\
\hline 10 & 2 & 41 & 6 & 73 & 6 \\
\hline 11 & 6 & 42 & 6 & 74 & 6 \\
\hline 12 & 6 & 43 & 6 & 75 & 6 \\
\hline 13 & 6 & 44 & 6 & 76 & 6 \\
\hline 14 & 6 & 45 & 6 & 77 & 6 \\
\hline 15 & 6 & 46 & 6 & 78 & 6 \\
\hline 16 & 6 & 47 & 2 & 79 & 6 \\
\hline 17 & 6 & 48 & 6 & 80 & 6 \\
\hline 18 & 6 & 49 & 6 & 81 & 6 \\
\hline 19 & 6 & 50 & 6 & 82 & 6 \\
\hline 20 & 6 & 51 & 6 & 83 & 6 \\
\hline 21 & 6 & 52 & 2 & 84 & 6 \\
\hline 22 & 6 & 53 & 6 & 85 & 6 \\
\hline 23 & 6 & 54 & 2 & 86 & 6 \\
\hline 24 & 6 & 55 & 2 & 87 & 6 \\
\hline 25 & 6 & 56 & 6 & 88 & 6 \\
\hline 26 & 6 & 57 & 2 & 89 & 9 \\
\hline 27 & 6 & 58 & 6 & 90 & 6 \\
\hline 28 & 6 & 59 & 6 & 91 & 6 \\
\hline 29 & 6 & 60 & 6 & 93 & 6 \\
\hline 30 & 6 & 61 & 6 & 94 & 6 \\
\hline
\end{tabular}


the middle Ozark aquifer and Western Interior Plains confining system (table 3, main text). On the other hand, some pilotpoint parameter groups had few large reductions in posterior variances - for example, specific yield in the lower Ozark aquifer, horizontal hydraulic conductivity in the St. Francois aquifer, and vertical hydraulic conductivities in the Ozark confining unit and the St. Francois confining unit (table 3, main text).

\section{Prediction Uncertainty}

The best-fit parameters gathered through the history matching process represent minimum error variance parameters. That is, model parameters retain uncertainty even after they have been subjected to the history-matching process, and the parameters are still free to movement with constraints. Therefore, many different parameter sets can reproduce the observation dataset as well as the best-fit parameter set (non-unique solutions). Each of these different parameter sets, however, may produce different model predictions, especially when large posterior uncertainty remains in parameters to which these predictions are sensitive. Predictive linear uncertainty analysis was used to evaluate uncertainty in predictions made by groundwater models based on best-fit parameters with explicit consideration of parameter uncertainty.

To propagate parameter uncertainty to predictions of interest, the following equations (Doherty and others, 2010; White and others, 2015) were used:

$$
\begin{gathered}
\sigma_{s}^{2}=y^{T} \Sigma_{\theta} \\
\overline{\sigma_{s}^{2}}=y^{T} \overline{\Sigma_{\theta}} y
\end{gathered}
$$

where

$y \quad$ is the sensitivity vector of prediction $s$ with respect to each of the adjustable parameters,

$\sigma_{s}^{2} \quad$ is the prior variance of prediction $s$,

$\overline{\sigma_{s}^{2}}$ is the posterior variance of prediction $s$, and

all other terms are as previously defined in equation 2.1 for Schur's complement.

As previously stated, linear uncertainty analysis using Schur's complement assumes: (1) a linear relationship between adjustable parameters and model-simulated observation equivalents, and (2) multivariate Gaussian (or log-Gaussian) distributions to describe the stochastic character of parameters, predictions, and observation noise (Fienen and others, 2010; White and others, 2015). Predictive linear uncertainty analysis assumes that the history-matching process transfers information from the observation dataset to parameters to which predictions are sensitive, thereby reducing the uncertainty of the model predictions - for example, the posterior uncertainty about a prediction should be less than the prior uncertainty.
The prior parameter uncertainty estimates for the predictive analysis were based on a range of the potential values for the parameters prior to the history-matching process. Using equations 2.2 and 2.3, the prior parameter uncertainty estimates were propagated to the model predictions. To evaluate the effects of the history-matching process on the predictions of interest, equations 2.2 and 2.3 were combined with equation 2.1 to generate posterior prediction uncertainty estimates. The posterior prediction uncertainty estimates were then used to estimate the upper and lower bounds of the 95-percent credible interval for each model prediction. For the heads targeted as predictions of interest, the radius of the 95-percent credible interval represents a conservative estimate of the expected margin of error for the head forecasts under the three scenarios of potential future conditions. The history-matching process provided important information to inform prediction-sensitive model parameters, contributing to substantial decreases in the radii of the posterior 95-percent credible intervals around the head forecasts (when compared to the prior; figs. 22-24, main text).

\section{The Worth of Data Pertaining Directly to Parameters}

Evaluating which parameters or groups of parameters are contributing most to the uncertainty associated with a particular prediction quantifies the worth of the data and facilitates informed data collection. The uncertainty in parameters and predictions that remains after history matching depends upon the uncertainty in parameters prior to history matching and the information on parameters contained in the observation dataset used in the history-matching effort. Linearbased uncertainty analyses (White and others, 2016) were used to quantitatively evaluate which parameters or groups of parameters are contributing most to the prior and posterior uncertainty associated with the 94 head forecasts.

The posterior uncertainty associated with each prediction is calculated by systematically assuming perfect knowledge of a selected parameter or group of parameters, which is equivalent to reducing the uncertainty of that selected parameter or group of parameters. If a prediction is sensitive to this particular parameter or group of parameters, then the posterior variance — or uncertainty — associated with that prediction should also be reduced. Comparison of the posterior uncertainty calculated under the assumed perfect knowledge of a selected parameter or group of parameters to the posterior uncertainty calculated with the unaltered posterior parameter covariance matrix can be used to identify the dominant sources of parameter contribution to uncertainty for each prediction of interest. 


\section{The Worth of Data Pertaining Indirectly to Observations}

Linear-based uncertainty analysis was also used to identify the most valuable head observations for predicting future conditions. The observations in the calibration dataset co-located with each of the 94 head forecasts at real-time observation wells were independently nominated as groups for removal (from the observation dataset used in the historymatching effort) for each of the three scenarios. The worth of the nominated observation or group of observations is measured as an increase in the posterior variance resulting from the loss of information, where the loss of information is the removed influence of the eliminated observations during the history-matching process. The percent increase in the posterior variance for each head forecast was calculated and then summed to gain a sense of how much predictive uncertainty increased for predicted water levels at all forecast locations. This type of data worth analysis is particularly useful in informing an existing groundwater monitoring network because it identifies which observations are most important in reducing predictive uncertainty for future water levels at all forecast locations.

For more information about this report, contact

Director, Lower Mississippi-Gulf Water Science Center

U.S. Geological Survey

640 Grassmere Park, Suite 100

Nashville, Tennessee, 37211

https://www.usgs.gov/centers/lmg-water

Publishing support provided by

Lafayette Publishing Service Center 


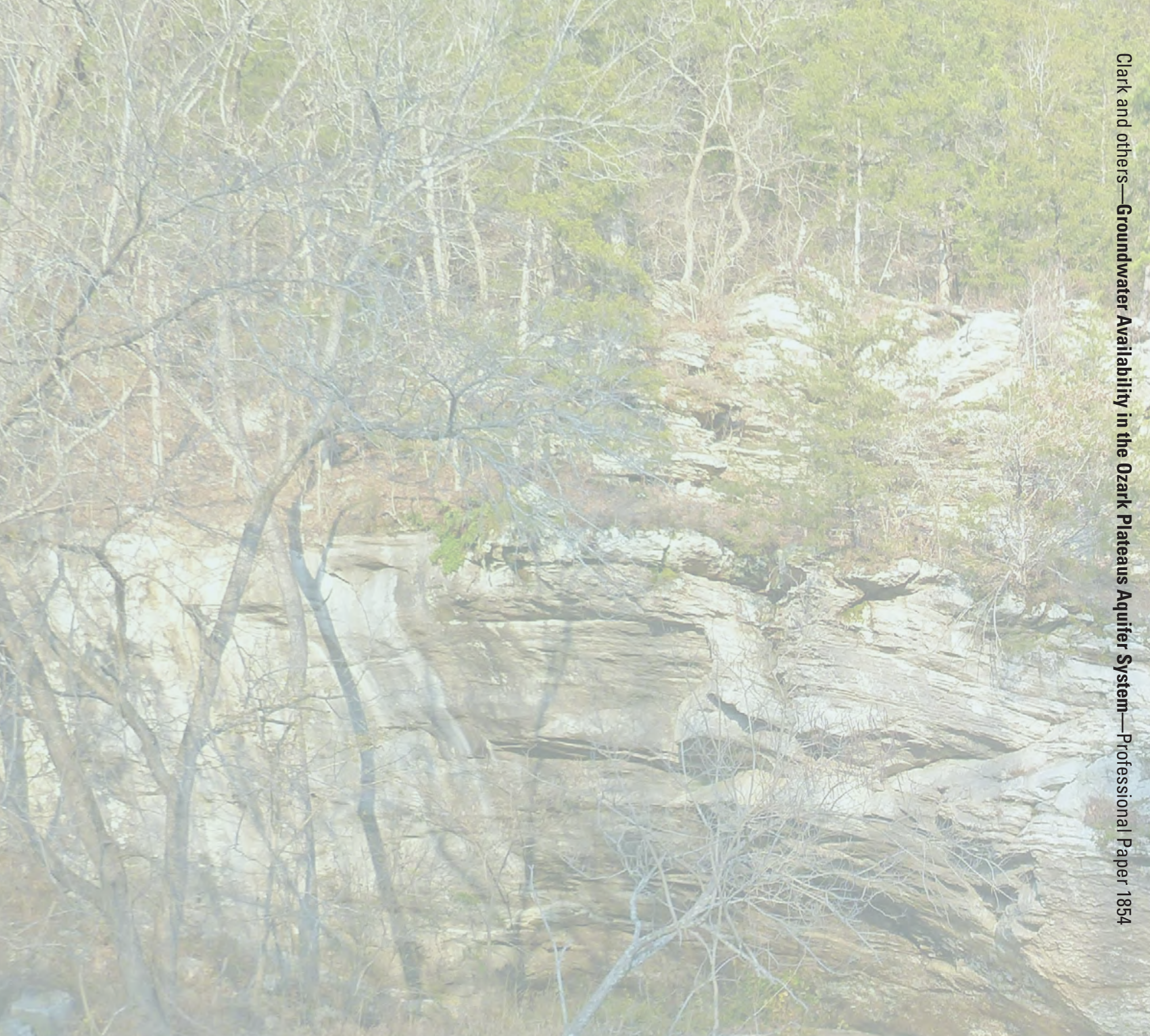

